ANDREW HYNES SERIES:

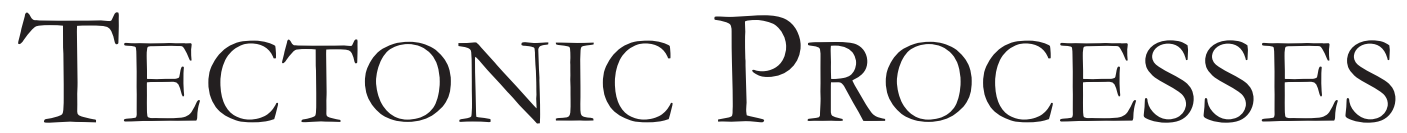

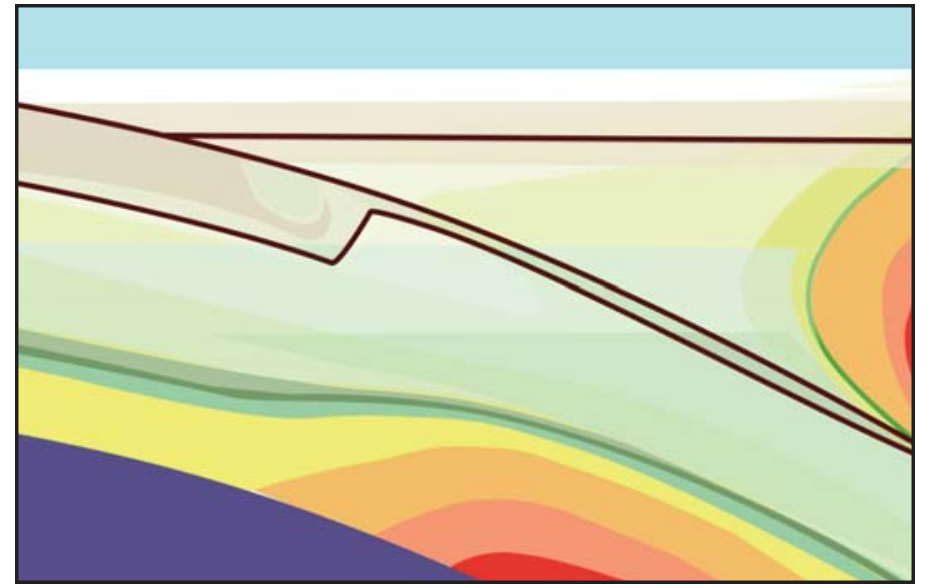

\section{Proterozoic-Paleozoic Sedimentary Rocks and Mesozoic-Cenozoic Landscapes of the Cape Mountains Across the Kango Complex Reveal 'More Gaps Than Record' from Rodinia and Gondwana to Africa}

\author{
Maarten J. de Wit*, Bastien Linol and \\ Vhuhwavhohau Nengovhela
}

\section{AEON-ESSRI, Africa Earth Observatory Network - Earth Stewardship Science Research Institute \\ Nelson Mandela University, South Africa \\ E-mail: Bastien.aeon@gmail.com}

\section{SUMMARY}

The Kango (Cango) region flanks the northern margins of the Klein Karoo and the Cape Mountains across the Western Cape Province of South Africa. It preserves a condensed Proterozoic-Paleozoic stratigraphy exposed via a Mesozoic-Cenozoic morphology with a present Alpine-like topography. Its rocks and landscapes have been repeatedly mapped and documented for the past 150 years. Over the last 25 years, we remapped and dated a central-eastern section of this region. The subvertically bedded and cleaved rocks reveal an 8-10 km thick stratigraphy covering more than 700 million years between ca. 1200 and $500 \mathrm{Ma}$ with several unconformities and disconformities. At ca. $252 \mathrm{Ma}$, during the Cape orogeny, this Kango Complex was deformed along thrusts and sub-isoclinal folds producing steeply dipping phyllites and slates. It was uplifted by $3-5 \mathrm{~km}$ during the Kalahari epeirogeny between 140 and $60 \mathrm{Ma}$ while eroding at ca. 100-200 m/m.y. (120-80 Ma). During the Cenozoic, the rate of uplift decreased by an order of magnitude and today is ca. $0.4-0.7 \mathrm{~m} / \mathrm{m} . \mathrm{y}$. across steep slopes and canyons in contrast to the Himalayas where erosion rates are about hundred times faster. A recent publication about this central-eastern section of the Kango region disputes the existence of regional isoclinal folds and suggests that deposition of the oldest sedimentary successions, including carbonate rocks of the Cango Caves (limestone-marble with enigmatic microfossils) was simple, continuous and restricted to between ca. 700 and $500 \mathrm{Ma}$, decreasing earlier estimates of the stratigraphic age range by 60-80\%. Similarly, recent interpretations of the complex landscapes link the northern contact between the Kango and Table Mountain rock sequences to Quaternary faults. We present a new geological database, mapped between 1:500 and 1:10,000 scales, and twelve stratigraphic sections with younging directions linked to structural and isotopic data that support repetitions along regional isoclinal folds and thrust zones of the Kango sequences during the Permo-Triassic Cape orogeny, and geomorphic data that link the origin of its landscapes to weathering and erosion during the CretaceousCenozoic Kalahari epeirogeny. During its evolution, the Kango Basin directly flanked both Grenvillian and PanAfrican Mountain systems. But, at an average sedimentation rate of ca. $1 \mathrm{~mm} / 70$ years $(0.014 \mathrm{~mm} /$ year $)$ and with present low erosion rates $(0.005 \mathrm{~mm} /$ year $)$, there is likely more time missing than preserved of the tectono-erosion across these different regions of Rodinia and Gondwana before Africa emerged. To further evaluate the geodynamic significance of these time gaps requires more field mapping linked to new transdisciplinary geosciences.

\section{RÉSUMÉ}

La région du Kango (Cango) flanque les marges nord du petit Karoo et des montagnes du Cap dans la province du Western Cape en Afrique du Sud. Elle préserve une stratigraphie con-

Geoscience Canada, v. 47, https://doi.org/10.12789/geocanj.2020.47.157 pages 7-58 $\quad$ C 2020 GAC/AGC®

* Deceased April 15, 2020. See https://doi.org/10.12789/geocanj.2020.47.156 
densée protérozoïque-paléozoïque exposée via une morphologie mésozoïque-cénozoïque avec une topographie actuelle de type alpin. Ses roches et ses paysages ont été cartographiés et documentés durant les 150 dernières années. Au cours des 25 dernières années, nous avons re-cartographié et daté une section du centre-est de cette région. Les roches litées de manière subverticale et clivées révèlent une stratigraphie de 8 à $10 \mathrm{~km}$ d'épaisseur couvrant plus de 700 millions d'années entre environ 1200 et $500 \mathrm{Ma}$ avec plusieurs non-conformités et disconformités. À $252 \mathrm{Ma}$, au cours de l'orogenèse du Cap, ce Complexe du Kango s'est déformé le long de chevauchements et de plis isoclinaux produisant des schistes à fort pendage. Il a été soulevé de 3 à $5 \mathrm{~km}$ au cours de l'épirogenèse du Kalahari entre 140 et $60 \mathrm{Ma}$, tout en s'érodant à 100-200 $\mathrm{m} / \mathrm{m}$.a. (120-80 Ma). Pendant le Cénozoïque, le taux de soulèvement a diminué d'un ordre de grandeur et il est aujourd'hui d'environ 0,4 à $0,7 \mathrm{~m} / \mathrm{m}$.a. à travers des pentes abruptes et des canyons, contrairement à l'Himalaya où les taux d'érosion sont environ cent fois plus rapides. Une publication récente sur cette section du centre-est de la région du Kango conteste l'existence de plis isoclinaux régionaux et suggère que le dépôt des plus anciennes successions sédimentaires, y compris les roches carbonatées des Grottes du Cango (marbre calcaire avec des microfossiles énigmatiques) était simple, continu et limité entre environ 700 et $500 \mathrm{Ma}$, diminuant les estimations antérieures de la tranche d'âge stratigraphique de 60 $80 \%$. De même, des interprétations récentes des paysages complexes relient le contact nord entre les séquences rocheuses du Kango et de Table Mountain à des failles quaternaires. Nous présentons une nouvelle base de données géologiques, cartographiée à des échelles entre 1:500 et 1:10,000, et douze coupes stratigraphiques avec des directions de superposition liées à des données structurales et isotopiques qui concordent avec les répétitions le long des plis isoclinaux régionaux et des zones de chevauchement des séquences du Kango pendant l'orogenèse permo-triassique du Cap, et des données géomorphiques qui relient l'origine de ses paysages à l'altération et à l'érosion au cours de l'épirogenèse du Kalahari au Crétacé-Cénozoïque. Au cours de son évolution, le bassin du Kango flanquait les systèmes montagneux grenvillien et panafricain. Mais, à un taux de sédimentation moyen d'environ $1 \mathrm{~mm} / 70$ ans $(0,014 \mathrm{~mm} / \mathrm{an})$ et avec les faibles taux d'érosion actuels $(0,005 \mathrm{~mm} / \mathrm{an})$, il manque probablement plus d'enregistrements de la tectonique et érosion de ces différentes régions de Rodinia et Gondwana avant l'émergence de l'Afrique que ce qui est actuellement préservé. Pour évaluer la signification géodynamique de ces intervalles de temps manquant, il faut d'avantage de cartographie de terrain associée à de nouvelles géosciences transdisciplinaires.

Traduit par la Traductrice

\section{INTRODUCTION}

Geographically, the topography of the Kango (in Afrikaans) or Cango (in English) across the Klein Karoo and Cape Mountains of southern South Africa comprises a paleo-plateau about 1200-1000 $\mathrm{m}$ above sea level (asl), incised by dendritic drainage valleys up to $400 \mathrm{~m}$ deep that originate along the southern flanks of the ca. $2000 \mathrm{~m}$ asl Swartberg Mountains (Fig. 1A), and from which tributaries, such as the Grobbelaars River, meander along the present east-west Cango Valley at ca. $600 \mathrm{~m}$ asl. In a few places along the Cango Valley, rivers diverge south in steep canyons that cut through this paleoCango plateau and in more open valleys across the lower Oudtshoorn Plateau at ca. $500 \mathrm{~m}$ asl, to join the larger Olifants River near Oudtshoorn at ca. $300 \mathrm{~m}$ asl (Figs. 1B and 2).

Lester King (1951; pers. comm. 1980) first suggested that the geomorphology of the Cango Valley, including the famous Cango Caves, represents a 'Tertiary' erosion surface with subsurfaces (caves) excavated along old fault zones linked to Cenozoic uplift of southern Africa. More recently, Geoffrey King (pers. comm. 2005; King and Bailey 2006) suggested that the distinct different elevations and geomorphic features separating the hard quartzites of the Swartberg Mountains and the softer sedimentary rocks of the lower lying Cango sequences are linked to Tertiary normal faulting along this contact.

More recent seismic and magnetic data (Stankiewicz et al. 2007; Lindeque et al. 2007, 2011; Weckmann et al. 2012) and fission track and cosmogenic geochronology (Tinker et al. 2008; Decker et al. 2011, 2013; Scharf et al. 2013; Kounov et al. 2015) across this area have shown that the uplift and erosion of the Cango Valley and adjacent mountain systems were linked to epeirogeny with rapid erosion rates (100-200 $\mathrm{m} / \mathrm{m}$.y.) during relatively wet conditions of the Early Cretaceous to mid-Cenozoic era, and decreased more than ten-fold during drier climate conditions in the late Cenozoic, reaching very low erosion rates of less than $0.4-1.5 \mathrm{~m} / \mathrm{m} . \mathrm{y}$. today and over the last 2 to 5 m.y. Thus, the rugged present-day topography across the Cango Valley and the Swartberg Mountains is inherited predominantly from the Cretaceous and has been only minimally re-sculptured by 200-300 m denudation during the late Cenozoic (Kounov et al. 2015). Lester King's 'Tertiary' surfaces, often covered by large quartzite pebbles and boulders are consequently late Mesozoic in age (Fig. 1C).

The famous Cango Caves formed within limestone and marble are massive sinkholes up to $2000 \mathrm{~m}$ long and 15-20 m high (Luttman-Johnson 1897), with a number of chambers along a subhorizontal shaft about $270 \mathrm{~m}$ below the surface of a well-preserved part of the paleo-Cango plateau ca. $1000 \mathrm{~m}$ asl. The caves are incised by a modern drainage that links to the more recent low-eroding surfaces $(<2 \mathrm{~m} / \mathrm{m}$.y. $)$ and dendritic drainage valleys $(3-6 \mathrm{~m} / \mathrm{m} . \mathrm{y}$; ; see Fig. $2 \mathrm{~b}$ and details below; for general information and images of the caves see https://en.wikipedia.org/wiki/Cango_Caves). Stalagmites within the Cango Caves are abundant and relatively recent in age (<200 ka; de Wit et al. unpublished).

Geologically, the Kango rocks across the Cango Valley were originally reported to be older than the Malmesbury Series (Ediacaran; Nama System) and thus linked to parts of the Namaqualand Schist (Dunn 1887), and named the 'Cango Beds' by Corstorphine (1886). Thereafter these rock sequences were mapped as 'a series of slates, grits and sheared conglomerates, among which bands of dolomite of very varying thickness occur', with 'quartz-feldspar-grit or porphyroids, and diabase in the form of numerous dykes, often much altered by 


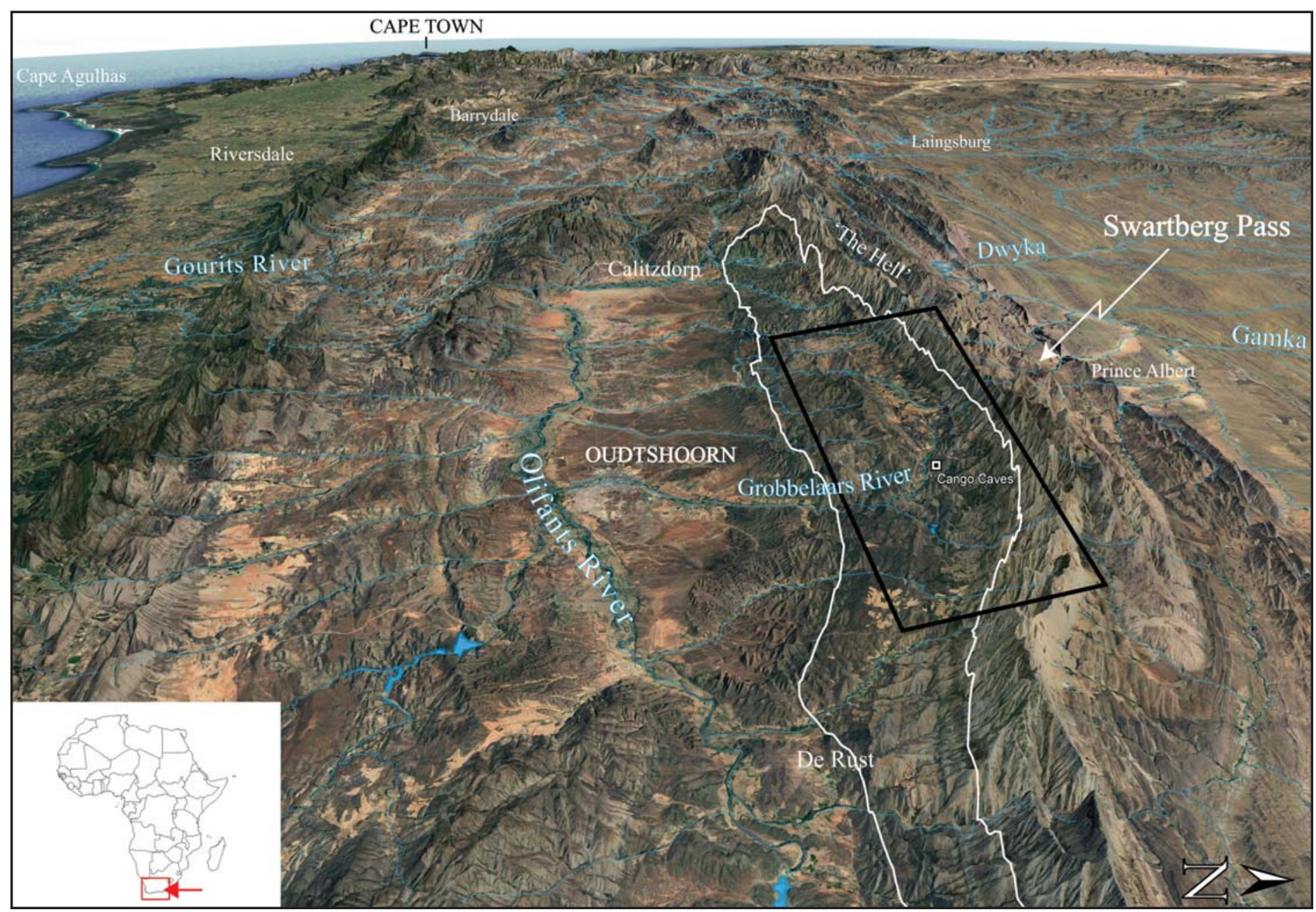

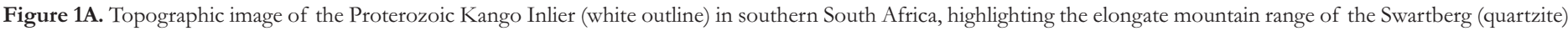

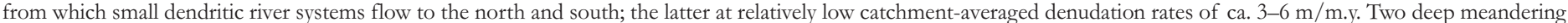

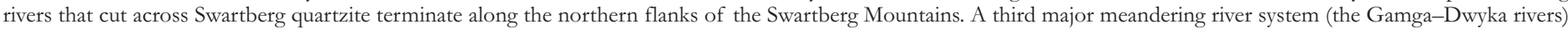

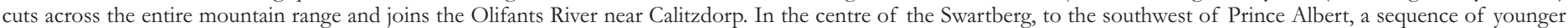

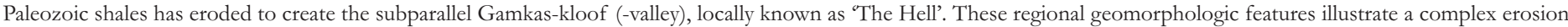

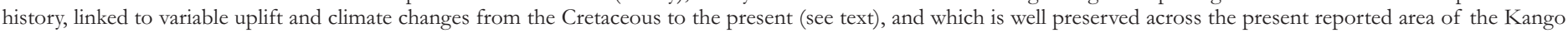
Complex (black rectangle).

shearing', and recorded as the 'Cango Series' (Corstorphine and Rogers 1897; Rogers and Schwartz 1900; McIntyre 1932).

Tectono-stratigraphically, the Kango sequences comprise folded and cleaved meta-sedimentary rocks interpreted to underlie unconformably the near-vertical conglomerates and quartzites of the Table Mountain Group (TMG) across the narrow Swartberg Range. A similar south-dipping tectonic sequence of TMG (with conglomerates) flanks the southern margin of the Kango rocks. The latter, in turn, is tectonically overlain by Upper Mesozoic 'Enon' red sandstones and conglomerates of the Uitenhage Group, exposed at the contact with the TMG quartzites by a listric fault that today is still seismically active (Fig. 2c; Söhne and Hälbich 1983; Gresse et al. 1993; Goedhart and Booth 2016; Linol and de Wit 2016).

The first detailed geological map $(1: 50,000)$ with sections across the central Cango region was produced by Stocken (1954). This is an exceptional map in that, for the first time, the lower sequences were recognised as a series of structurally repeated, subvertical limestone and shale units along east-west regional isoclinal folds and refolds, separated from younger sequences by large-scale thrusts. In particular, a major isoclinal antiform, with an axial strike length of ca. $7 \mathrm{~km}$, was shown to duplicate the lowermost stratigraphy of the Cango Group, then named the Hilda Series. However, no dips of the fold limbs or fold axis, nor their plunges are shown on Stocken's map.

Subsequently, the structural complexity of these tectonic features was mapped in greater detail across the entire Cango region (Le Roux 1977, 1983; Le Roux and Gresse 1983), as recorded in a special publication of South Africa's National Geodynamics Programme (Söhne and Hälbich 1983; Nicolaysen 1983). This field work established a more detailed stratigraphy of seven formations (Fig. 3), in which, for example, the Hilda Series was renamed the Matjies River Formation, as part of a Goegamma Subgroup that, together with an overlying Kansa Subgroup, were referred to as the Kango Group and 


\section{Swartberg Pass Panorama}

\section{Cango Valley Panorama}
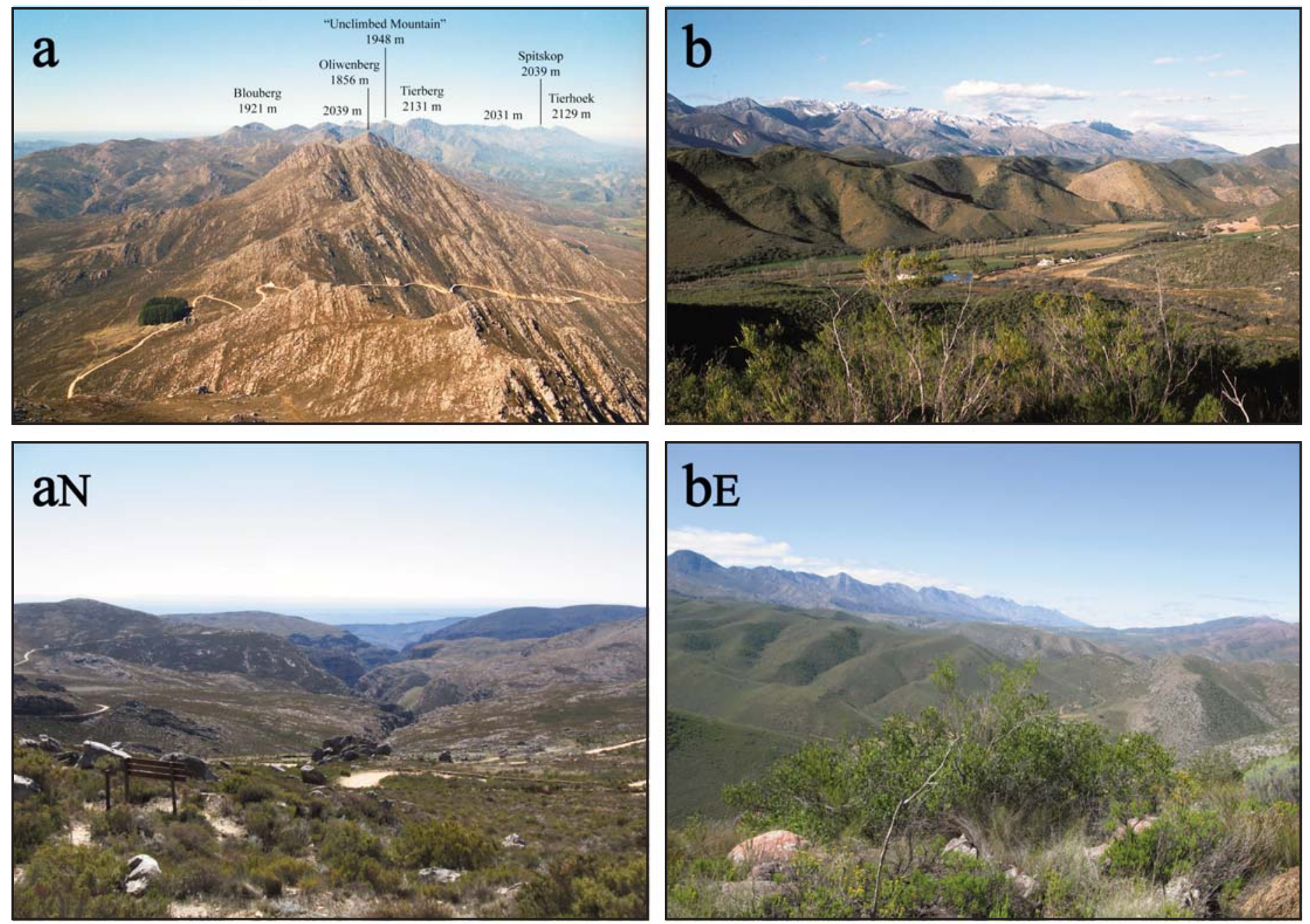

\section{bE}
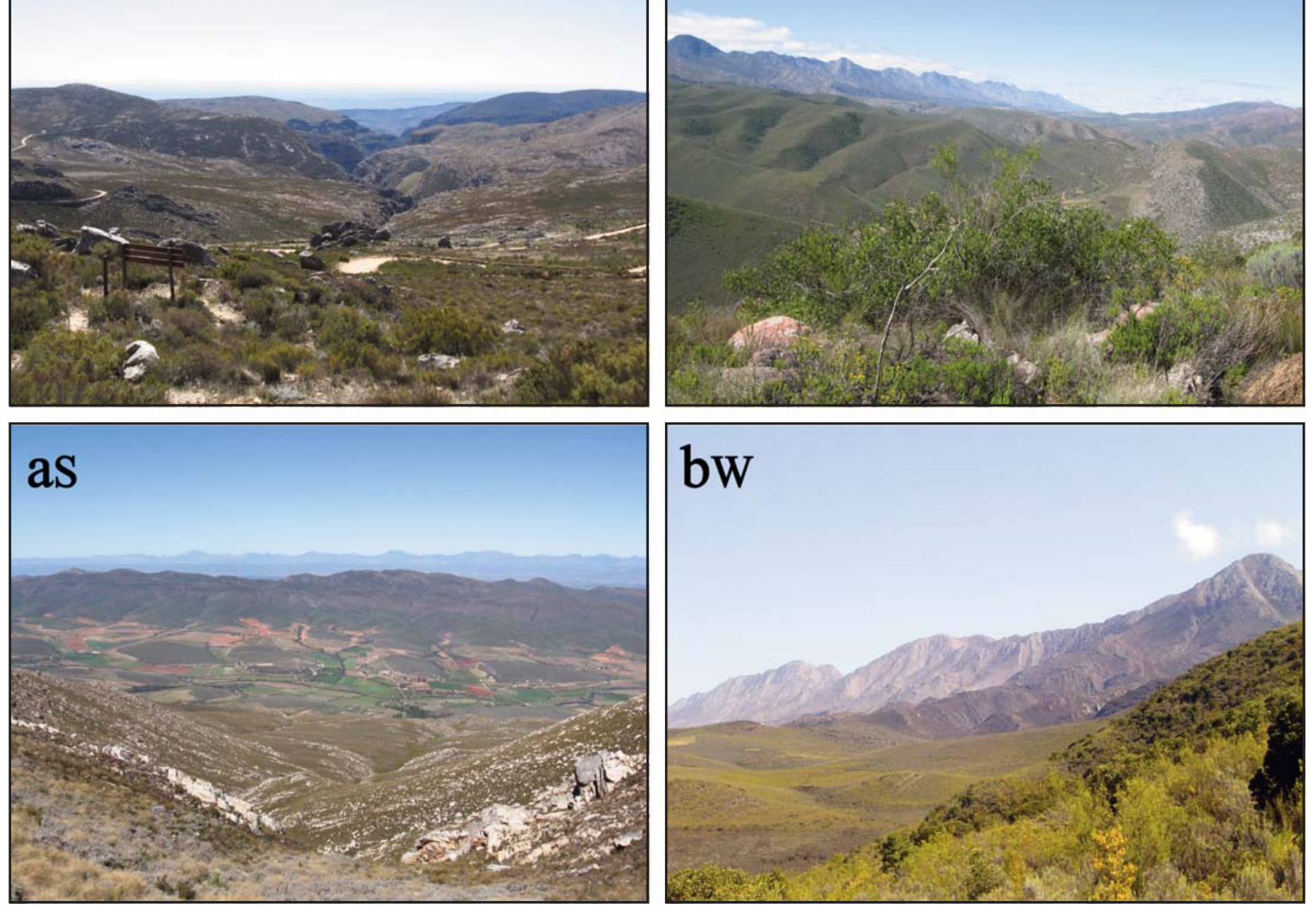

Figure 1B. Landscape photographs flanking the Cango Valley. (a) Northeast-focused view across the Swartberg Mountains near the road crossing the Swartberg Pass at 1583 $\mathrm{m}$ asl along the road towards Prince Albert and the Karoo Basin (to the north; $\mathrm{a}_{\mathrm{N}}$ ) and the Kango Basin (to the south; $\mathrm{a}_{\mathrm{S}}$ ). Beds of Table Mountain Group (TMG) rocks (quartzites of the Lower Paleozoic Cape Supergroup) are overturned, dipping steeply south and younging north. (b) Views across the Cango Valley taken $15 \mathrm{~km}$ to the south of the Swartberg Pass, highlighting remnants of a wide open, relatively flat erosion surface near $1000 \mathrm{~m}$ asl across the Kango rocks and presently cut by the Grobbelaars River meandering across another flat surface, with farmland, at ca. $750 \mathrm{~m}$ asl ( $\mathrm{b}_{\mathrm{E}}$, view to east and $\mathrm{b}_{\mathrm{W}}$, view to west). 

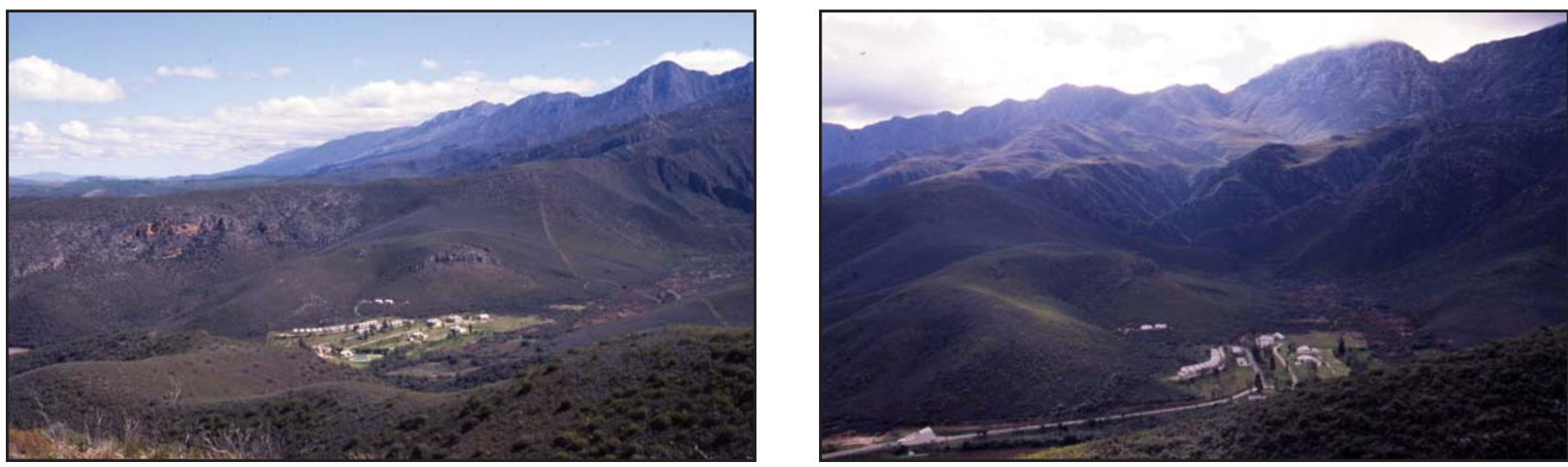

Figure 1C. West-facing views, taken from slightly different angles, across the $1200 \mathrm{~m}$ asl paleo-Cango Valley (ca. $200 \mathrm{~m}$ above De Hoek Camping Resort - pale green grass) linked to the Swartberg Mountains (top right) along gentle to open paleoslopes. These remnant flat surfaces of Late Mesozoic age are incised by steep dendritic drainage valleys linked to wider sections like near the resort. There is no field evidence of faults that might have initiated these younger geomorphologic valleys. The changes in valley systems are linked to precipitation and tectonic changes during the Kalahari epeirogeny from around 140 to $60 \mathrm{Ma}$ (see text).
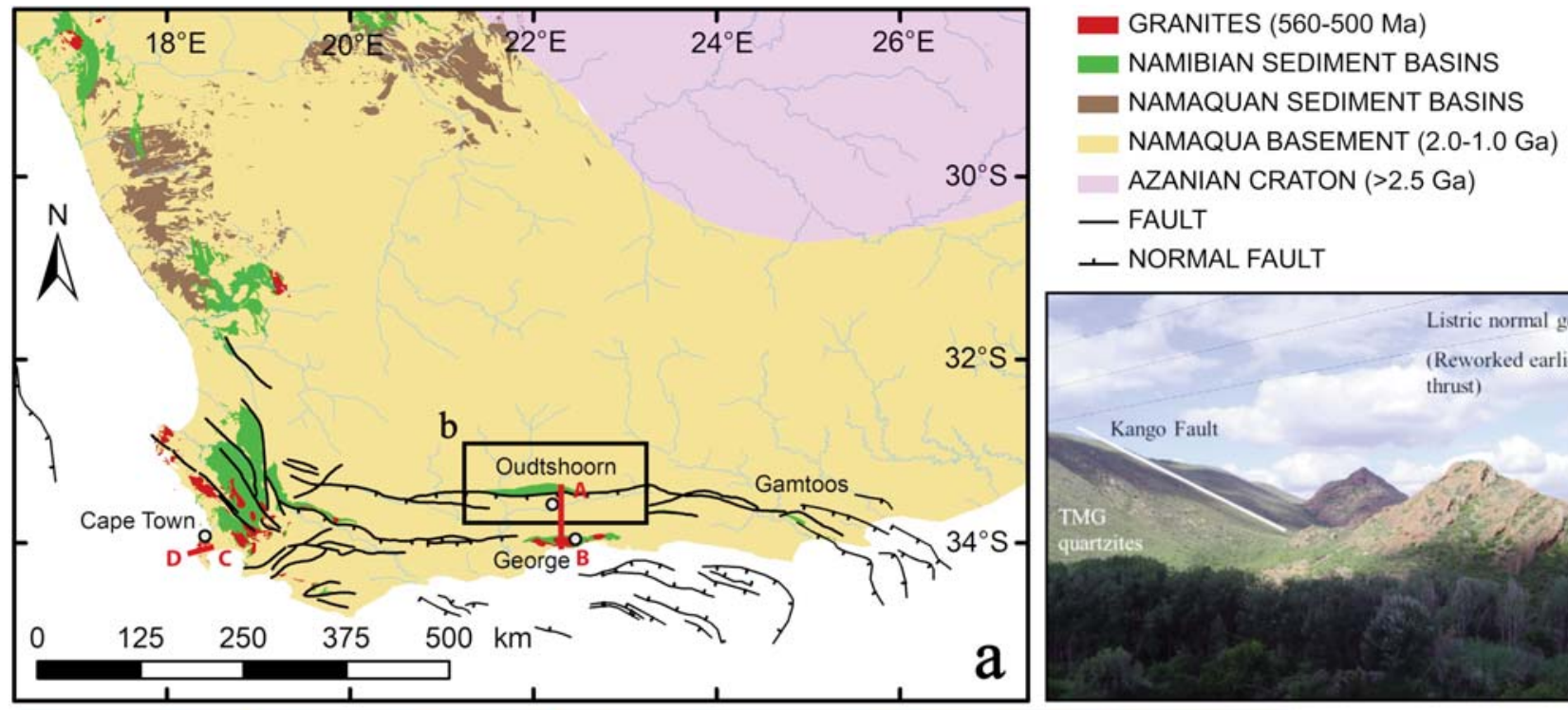

- GRANITES (560-500 Ma)

- NAMIBIAN SEDIMENT BASINS

- NAMAQUAN SEDIMENT BASINS

NAMAQUA BASEMENT (2.0-1.0 Ga)

AZANIAN CRATON (>2.5 Ga)

- FAULT

- NORMAL FAULT

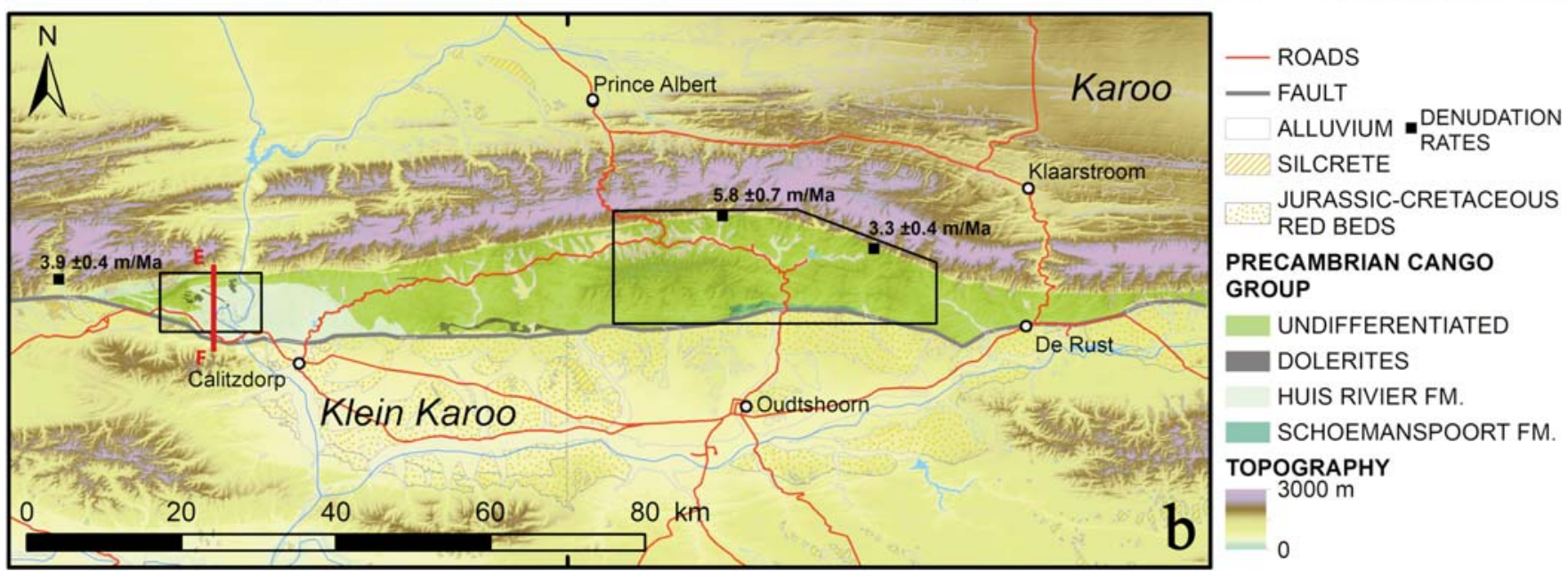

Figure 2. (a) Simplified geological map of the Cango/Kango region across Paleo- to Neoproterozoic crust of the Namaqua Natal Belt bordering the southern margin of the Archean Azanian craton; cross-sections A-B and C-D are shown in Figure 37. (b) The Proterozoic to Paleozoic Cango Group forms the southern flank of the Swartberg Range of the Cape Mountains, bounded to the south by a major Mesozoic-Cenozoic fault system (c). Black polygons delineate the study areas; cross-section E-F is shown in Figure 30. The low denudation rates across a number of variable river systems are from Scharf et al. (2013). 


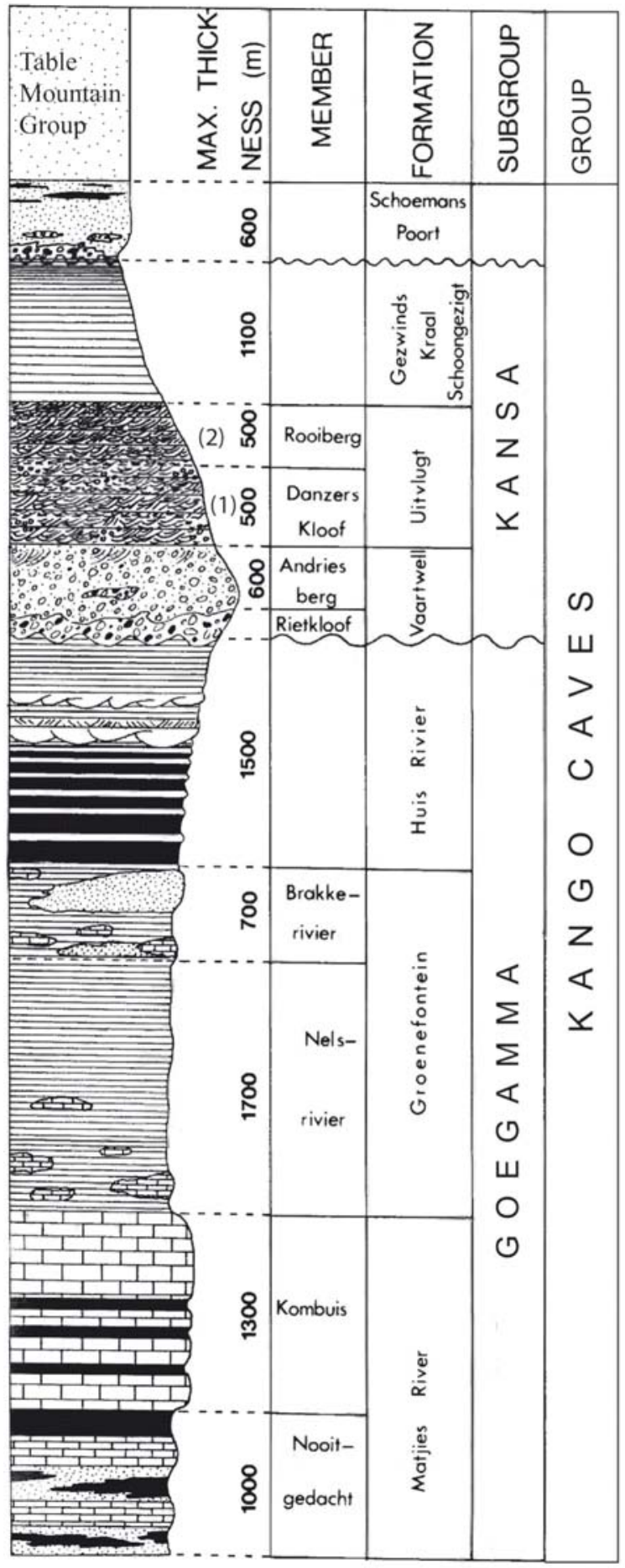

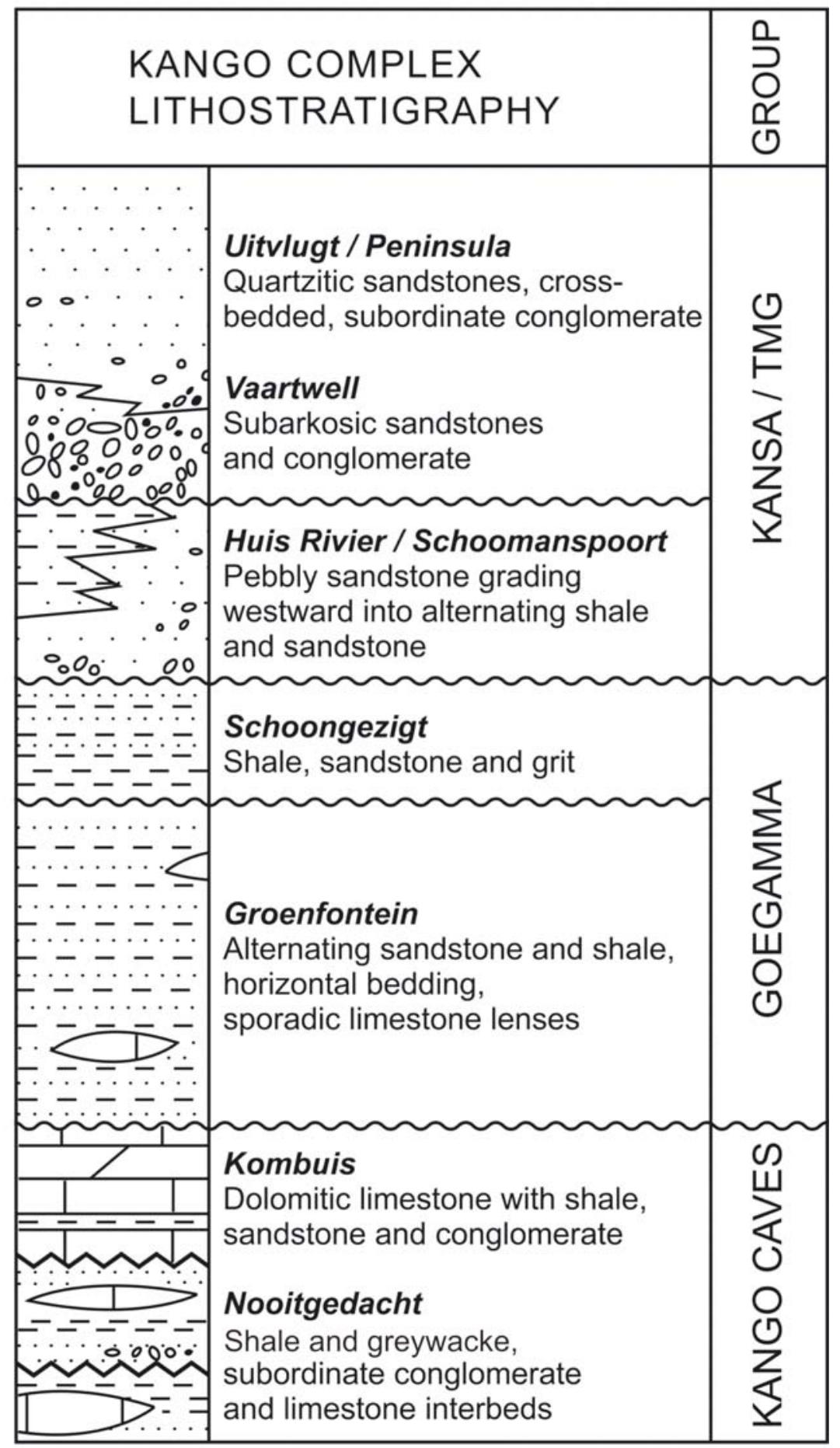

Figure 3. Stratigraphy of the Kango Complex. (Left) Modified from Le Roux and Gresse (1983), with subgroup (Goegamma and Kansa) renamed, and with members Danzerkloof (1) and Rooiberg (2) as inverted by Naidoo et al. (2013). (Right) Simplified lithostratigraphy redivided here into three groups as described in detail across twelve field sections in this study. In this new framework the Schoongezigt Formation is part of the Goegamma Group; the Schoemanspoort Formation links to the base of the Kansa Group; and the Uitvlugt Formation of the upper Kansa Group is of equivalent age to the lower TMG (Table Mountain Group). Major unconformities: wavy lines = previous work; angular lines $=$ this work.

separated by a major unconformity (Le Roux and Gresse 1983; Gresse et al. 1993). Both the subgroups were shown to be unconformably overlain at different localities and stratigraphic levels by the TMG.
This previous work also yielded a map with eight detailed sections that cover the exposed stratigraphy of the Kango inlier west of $23^{\circ} \mathrm{E}$ (from east to west, ca. $150 \mathrm{~km}$ long and $14 \mathrm{~km}$ wide across the central Cango region; Le Roux et al. 1983). 
The sections highlight the regional south-dipping folds and fault systems, but on which the major fold closure recognised by Stocken is poorly displayed. This fold, and many sub-folds along its limbs, was later remapped and measured in detail as a steep $\left(>70^{\circ}\right)$ west-plunging anticline by numerous groups of students at UCT and NMU.

The Kango stratigraphy has since been subdivided further through more local mapping and petrology, often linked to new metamorphic analyses, geochemistry, and dating techniques that confirmed a Neoproterozoic-Early Paleozoic age range of the upper sequences using detrital zircons (e.g. Le Roux and Smit 1995; Barnett et al. 1997; Fölling 2000; Frimmel et al. 2001; Frimmel 2009; Van Staden 2011; Naidoo et al. 2013).

Sedimentary structures preserved in many field sections across the Kango sequences are commonly overprinted and replaced by macroscopic regional schistosity/cleavage, linked to microscopic minerals such as sericite, chlorite and carbonate flakes of low-grade metamorphism (Stocken 1954; Le Roux 1983; Hälbich 1983a, b; Barnett et al. 1997; Frimmel et al. 2001), at about $350^{\circ} \mathrm{C}$ (Halbich 1983a, b), consistent with isochore data from oxygen isotopes in quartz-calcite veins that yield trapping temperatures up to $410^{\circ} \mathrm{C}$ (Egle et al. 1995, 1998; Egle 1996).

All Kango rocks reveal moderate paleo-weathering based on CIA (Chemical Index of Alteration) with arenite showing slightly higher CIA than carbonate rocks. Overall, the alteration values are relatively homogeneous with slightly increased alteration stratigraphically upward across the siliciclastic sequences of the Kansa Subgroup (Naidoo 2008; Naidoo et al. 2013).

\section{$\mathrm{U} / \mathrm{Pb}$ Geochronology}

\section{Detrital Zircon Dates from the Kango Sequences}

Stocken (1954) was the first to describe in detail zircons in both sedimentary rocks and intrusions across the Cango region. Typically sandstone (arenite) is rich in zircon (30-60\% of all non-opaque heavy minerals), apatite (up to $50 \%$ ), and rutile (minor), and there is a marked similarity in heavy minerals from different formations that range from well-rounded to angular, all commonly coated with iron oxide (e.g. Stoken 1954; Barnett 1995; Naidoo 2008).

$\mathrm{U}-\mathrm{Pb}$ analysis of detrital zircons to test an age difference between the lowermost sandstone of the Kansa Subgroup (Rietkloof Unit of the Vaartwell Formation; Fig. 3, left) and subvertical shales of the underlying Groenfontein Formation of the Goegamma Subgroup yielded a maximum Late Cambrian age in the former, with ${ }^{206} \mathrm{~Pb} /{ }^{238} \mathrm{U}$ date of ca. $518 \pm 9 \mathrm{Ma}$ found directly above the unconformity separating these two sequences (Barnett et al. 1997). The samples also revealed a subset of well-rounded zircon grains with Mesoproterozoic dates around $1100 \mathrm{Ma}$.

By contrast, near euhedral zircon grains from a coarse feldspathic grit near the bottom of the Kango Caves Group (Nooitgedacht Member; Fig. 3, left) only yielded ${ }^{206} \mathrm{~Pb} /{ }^{238} \mathrm{U}$ dates between 1200 and $1050 \mathrm{Ma}$; and a number of detrital zircons from carbonate conglomerate (diamictite) of the Matjies
River Formation along the road to the Cango Caves yielded dates between 1360 and $1060 \mathrm{Ma}$ (Barnett 1995; Barnett et al. 1997; de Wit et al. unpublished).

$\mathrm{U}-\mathrm{Pb}$ detrital zircon dates from a much larger number of sampled sequences across the Cango region confirm the Cambro-Ordovician age of the Kansa Subgroup, with a predominance of Early to Middle Cambrian zircons, and with older Mesoproterozoic grains ranging from ca. $1034 \pm 2$ to $1377 \pm$ $14 \mathrm{Ma}$ and 1800-1900 Ma. In addition, a number of Neoproterozoic zircons in the Kansa and the lower TMG sequences were recorded with dates ranging from 620 to $911 \mathrm{Ma}$ (Naidoo et al. 2013) and abundant Mesoproterozoic and Neoproterozoic ages were found in the Huis Rivier Formation of the Goegamma Group to the west of the present study area (ca. $1029 \pm 7$ to $1083 \pm 40 \mathrm{Ma}$, and 571 to $911 \mathrm{Ma}$; Naidoo et al. 2013). A lack of GPS locations for these samples does not allow further detailed analysis and stratigraphic comparison.

\section{Igneous Zircon Dates from Felsic and Mafic Dykes}

In two places across the lowermost Kango Caves Group, felsic dykes cut the Nooitgedacht sequences. These dykes have not been described or reported on before. The best exposed dykes are found along the southern section of the Raubenheimer Dam (see Map 1 and Section 5), where they cut across thick bedded sandstone. Zircons from two of these felsic dykes, both of which are cleaved and partially weathered, yield a concordant $\mathrm{U}-\mathrm{Pb}$ date of ca. $1072 \pm 5 \mathrm{Ma}$. At a second locality, along the road section $700 \mathrm{~m}$ before the turn-off to the Cango Caves (see Map 1 and Section 6), at least five thin subvertical felsic dykes cut across thinly bedded, folded (vertical axis) sandstone and carbonate rocks. Zircons from three of these dykes yielded a concordant $\mathrm{U}-\mathrm{Pb}$ date of ca. $1078 \pm 5 \mathrm{Ma}$. Thus, the lower sequences of the Kango Complex are Mesoproterozoic in age.

A number of mafic dykes across the Kansa rocks in the eastern section of the Kango Complex (see Fig. 2b) yielded younger ages: the first, a dolerite-gabbro with a $\mathrm{U}-\mathrm{Pb}$ zircon date of ca. $512 \pm 10 \mathrm{Ma}$ (Haas 1998); and the second, a schistose dyke with a U-Pb zircon date of ca. $460 \pm 5 \mathrm{Ma}$ (de Wit et al. unpublished). Thus, these mafic dykes are Early Paleozoic in age, although the date of the second dyke may have been partially reset during the formation of its schistosity at $252 \mathrm{Ma}$ (Booth 2011; Blewett and Phillips 2016; and see below).

While the precise ages of the stratigraphic sequences between the upper and lower Kango Complex remain unknown, our mapping confirms a relatively thin, but complex tectono-stratigraphy over a period of more than 700 million years. In contrast, more recent work questions the fold and fault systems, and recognises only unconformities mapped previously. This results in a simplified stratigraphy, confining the age of the lower Cango sequences between ca. 700 and 500 $\mathrm{Ma}$ (Nel et al. 2018). Previous $\mathrm{Pb}-\mathrm{Pb}$ double spike isochron data from the Kombuis carbonate units yielded an age of ca. $553 \pm 30 \mathrm{Ma}$, and $\mathrm{C}$ and $\mathrm{Sr}$ isotope signatures similar to those found in sequences separating a pre-Ediacaran from a Vendian (Ediacaran) age (Fölling 2000; Frimmel et al. 2001; Frimmel 2009). However, the clastic nature of the carbonate rocks 


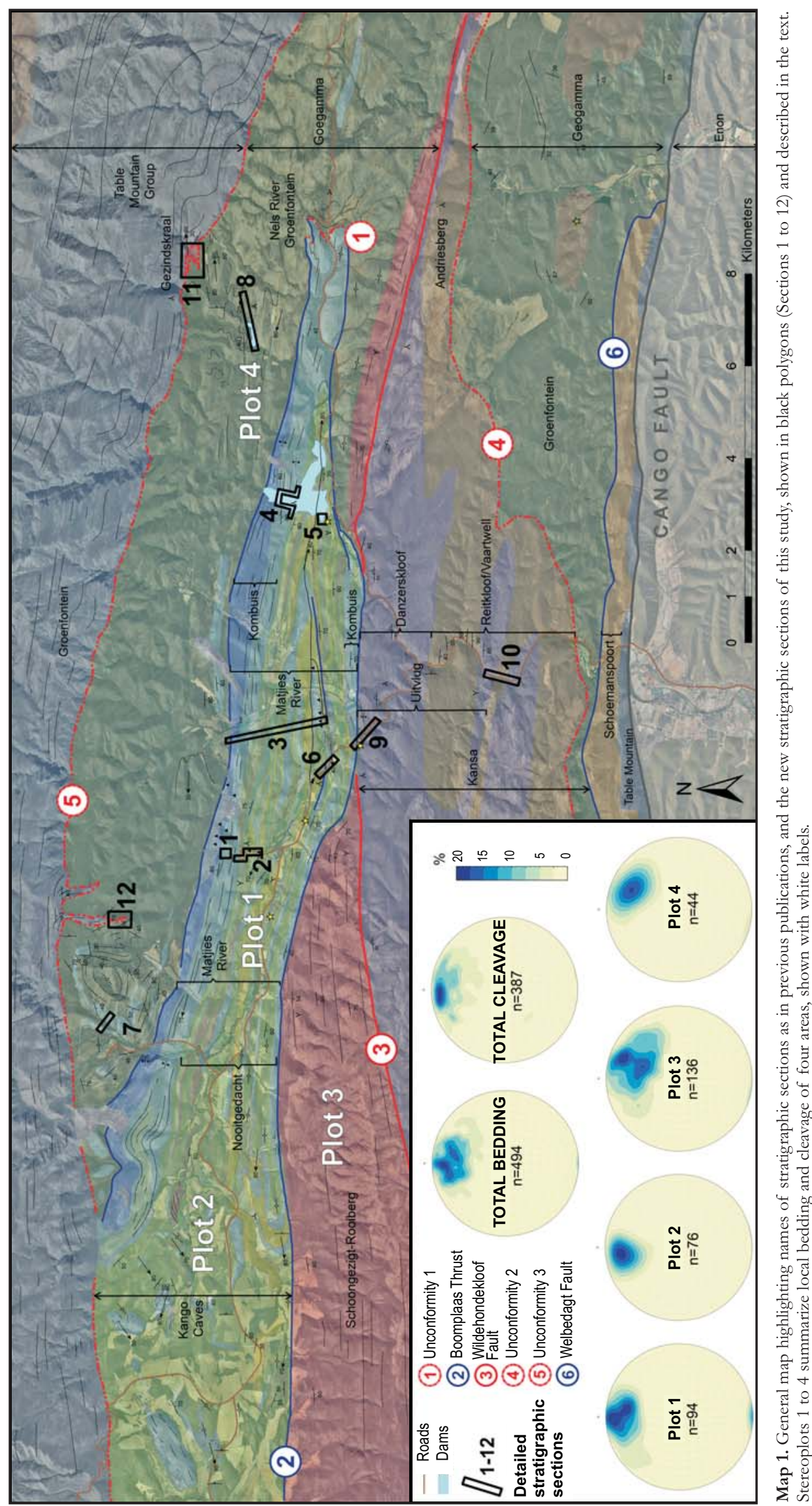




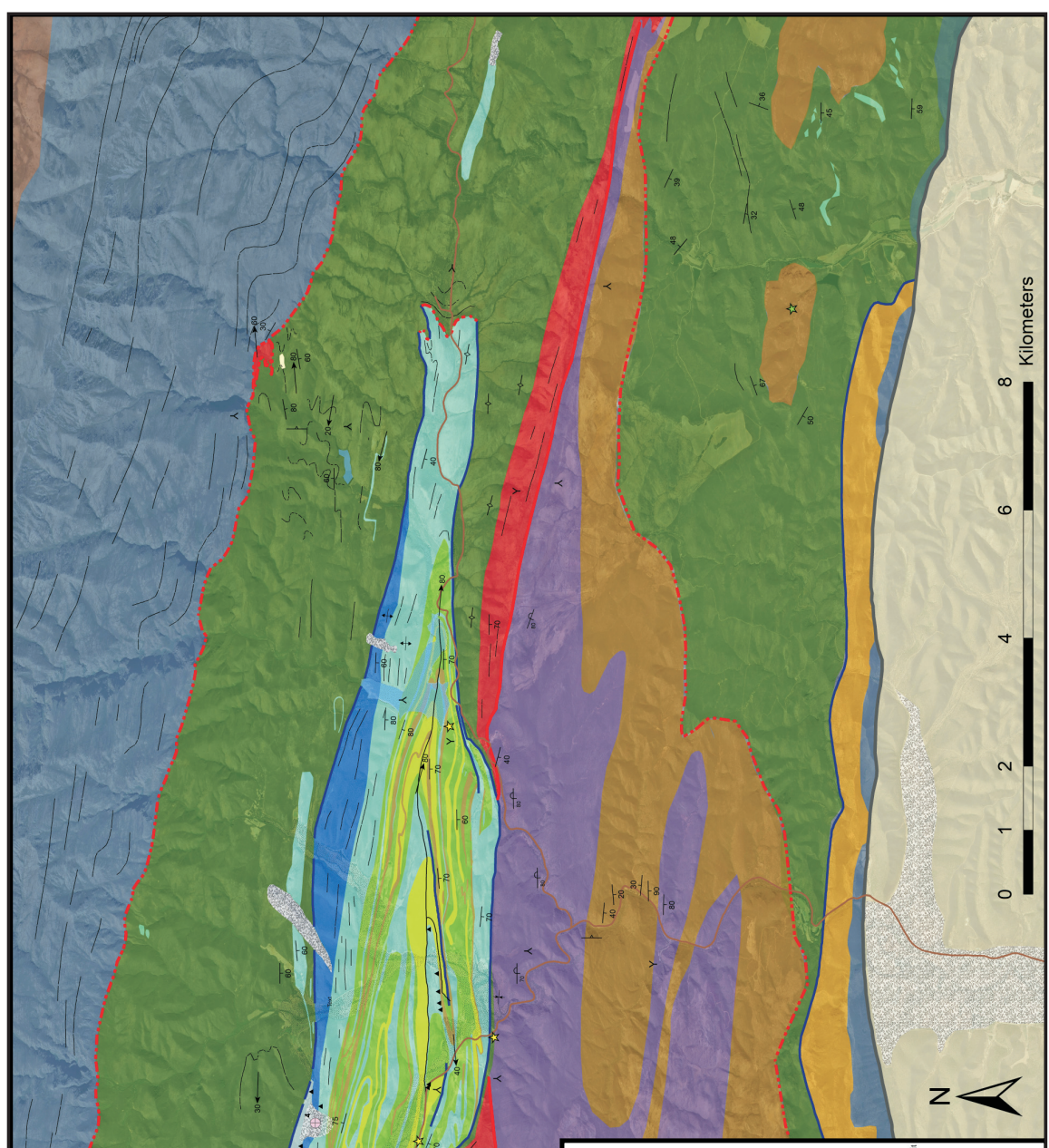

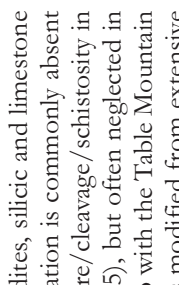

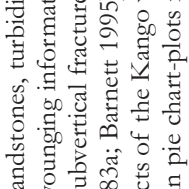

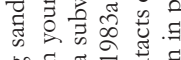

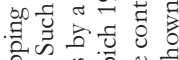

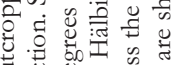

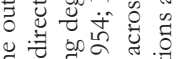

하을

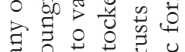

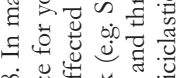

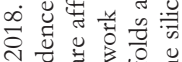

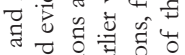

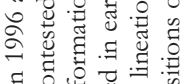

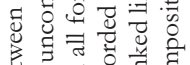

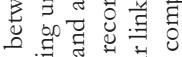

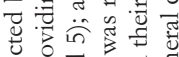

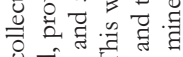

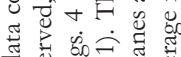

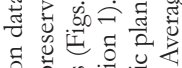

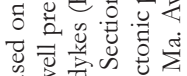

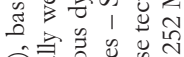

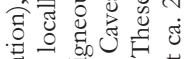

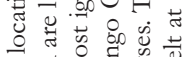

常. 둥

ㄴ.

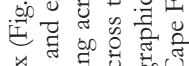

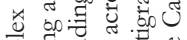

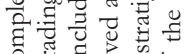

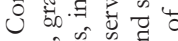

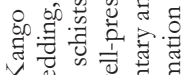

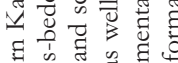

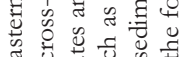

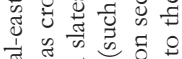

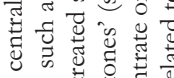

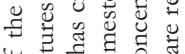

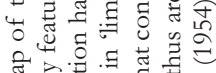

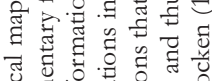

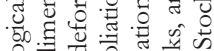

政

on

茫药

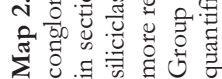


(detailed below and in Section 2) questions the primary nature of these different data.

These major disagreements justify stratigraphic testing which we present here based on long-term field mapping across the central-eastern Cango region and geochemical analyses in RSA, Australia, USA, Canada, and Europe over the last 22 years. We provide a detailed geological map (Map 2) and twelve sections, two of which are linked to new U-Pb zircon dates on felsic igneous intrusions, and we re-examine the stratigraphy and tectonic history of this unique inlier within the Cape Mountains.

\section{REVISED GEOLOGICAL MAP}

Mapping was conducted using various sets of aerial photographs, enlarged at scales between 1:500 and 1:10,000 over 22 years (1997-2019) and consolidated at a scale of 1:25,000 (GIS available online: www.aeon.org.za/cangomap). The results, including measured planar fabric, dip and fold axis, are summarized here on condensed maps with linked stereoplots (Maps 1 and 2). This work reveals four major stratigraphic sequences with strikingly different ages, separated by three regional unconformities and two major tectono-sedimentary boundaries, one of which links to a major molasse-type sequence (simplified on Fig. 3; and see below).

Tectonic structures complicate reconstruction of precise stratigraphy, locally and regionally (Fig. 4). The two oldest sequences (formerly the Matjies River and Groenfontein formations) are isoclinally folded with major fold axes plunging steeply east and west, which makes the measurement of total thicknesses difficult, something that was clearly recognised by Stocken (1954). These are tectonically overlain along the Boomplaas Thrust to the south by a sequence of red beds (the Schoongezigt and Gezwinds Kraal formations, in total about $1000 \mathrm{~m}$ thick), and in turn unconformably overlain across the Wildehondekloof Fault by more than 1500 m thick conglomerates and greywackes, referred to as the Vaartwell and Uitvlugt formations (Le Roux and Gresse 1983). To the north, this 'Kango Complex' underlies north-younging quartzites of the Peninsula Formation, the lowermost unit of the TMG, but which in places is overturned, dipping $40-70^{\circ}$ to the south (Fig. 1B). A sliver of hard quartzites, also from the TMG, bounds the southern edge of this complex along the Cango Fault (Map 1).

Before reporting on twelve detailed new sections, we first summarize below the wide range of ductile-brittle deformational features and structures, especially cleavage and schistosity, that occur throughout most of the study area, but which are generally not reported and/or interpreted as sedimentary structures.

\section{Variable Regional Deformation Structures - Shear Zones, Schists and Faults}

Published geology of the Cango region generally underplays the existence of major deformational features such as folds, shear zones and faults. Here we highlight some of these structures and elaborate on them in the following field sections and on Map 2.
Deformational features in thick limestone and marble are particularly difficult to quantify because of limited preservation of original bedding and low strain recrystallization. Occasional carbonate (dolomite) beds of dark colour reveal internal isoclinal folding (Fig. 4A). Deformed limestone and carbonate conglomerate are well preserved throughout the lower sequences (Fig. 4B). In many places, these foliated carbonate rocks locally reveal mylonitic textures, including in and adjacent to the Cango Caves (Fig. 4C).

\section{General Regional Stratigraphy}

We have changed the stratigraphic successions of the Cango region by recasting the present two subgroups and one group into three groups: the Kansa, Goegamma and Kango Cave Groups, based on the identification of major unconformities and several tectonic boundaries (Fig. 3, right; and detailed below). In addition, our new mapping is consistent with recent detrital zircon data (e.g. Naidoo et al. 2013), which confirm that the upper Kansa Group overlaps in age with the Table Mountain Group (TMG).

The two oldest sequences of the Kansa Group are separated by two major unconformities, commonly tectonically overprinted, the younger sequence of which, with sandstones and conglomerates of the Andriesberg Formation (formerly a member), has detrital zircons dated at $518 \mathrm{Ma}$ (Barnett et al. 1997), and is thus Cambrian (or younger) in age. This age is similar to that of detrital zircons in the lowermost formation (Peninsula Formation) of the TMG along Table Mountain in Cape Town, dated at $520 \mathrm{Ma}$ in the same laboratory (Armstrong et al. 1996; Scheepers and Armstrong 2002), and from the same lowermost TMG quartzite in the Swartberg Mountains flanking the Kango rocks (518 to $504 \mathrm{Ma}$; Naidoo et al. 2013). Stratigraphically younger zircon grains (ca. $471 \mathrm{Ma}$ ) occur in conglomerate and sandstone sequences of the Gezindskraal Formation, the lowermost section of which is unconformably below the TMG, and directly above the Groenfontein Formation (Map 2).

Elsewhere the Huis Rivier and Schoemanspoort formations have detrital zircons dated between 620 and $485 \mathrm{Ma}$ (Naidoo et al. 2013). Thus, the entire Kansa Group is younger than ca. $520 \mathrm{Ma}$ (Cambrian) and possibly ca. $470 \mathrm{Ma}$ (Silurian), predominantly derived from Late Neoproterozoic sources dated between 650 and $620 \mathrm{Ma}$ (Barnett et al. 1997; Naidoo et al. 2013).

The overlying Vaartwell and Uitvlugt sequences comprise thick conglomerates (with various granite clasts) interbedded with and fining upwards into cross-bedded sandstones and siltstones (Section 9). The large-scale ripple cross-laminations with mud drapes and common rip-up clasts suggest a shallow marine, wave-dominated paleo-environment (e.g. Walker and James 1992). This is similar to, albeit deeper than, the coastal marine setting generally proposed for sedimentation of the more mature quartzites of the Peninsula Formation (Shone and Booth 2005).

In general, pre-Goegamma arenites have microscopic textures of quartz-rich tectonites modified by fracturing and recrystallization of a crenulated chlorite-sericite matrix (Fig. 


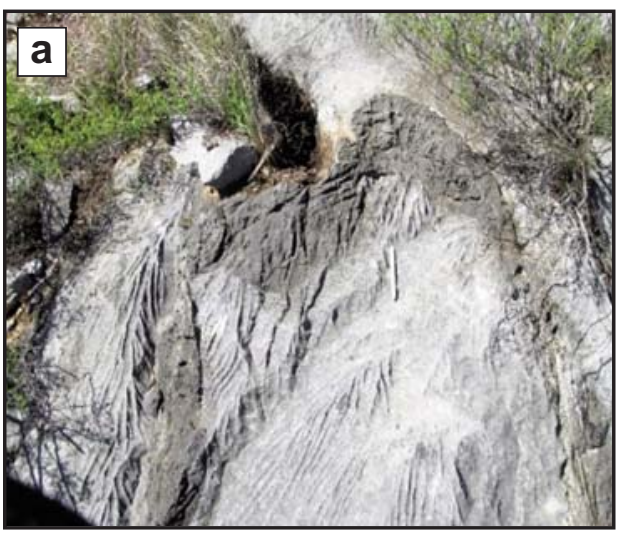

Figure 4A. (a, b) Examples in the Cango Caves limestone and marble of near-isoclinal folds, and (c) folded and boudinaged dolomite layers (pale grey), with white calcite extension fractures in clastic limestone (dark grey). For location a-b see Section 1; location c, Raubenheimer Dam, see Section 4.
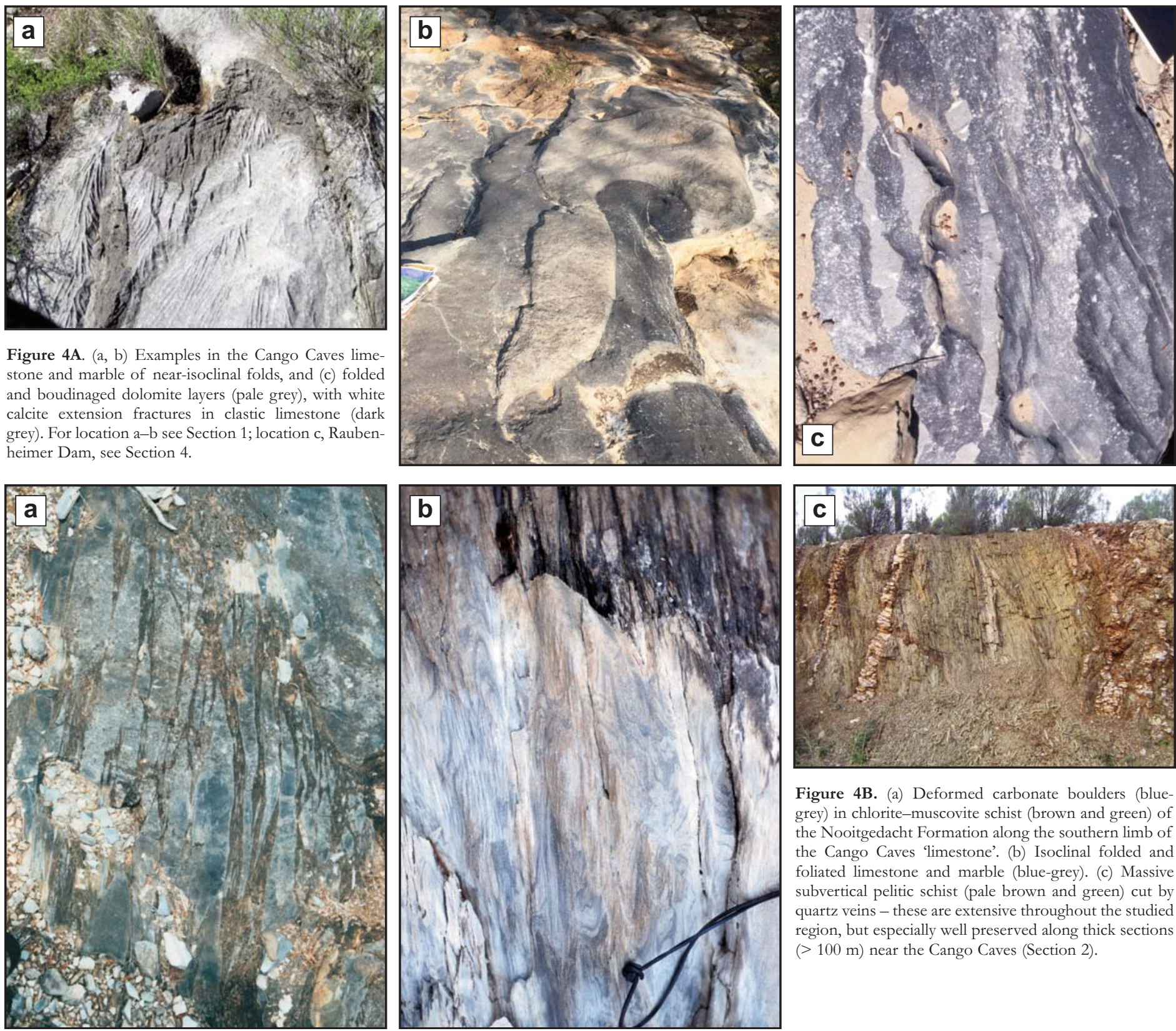

Figure 4B. (a) Deformed carbonate boulders (bluegrey) in chlorite-muscovite schist (brown and green) of the Nooitgedacht Formation along the southern limb of the Cango Caves 'limestone'. (b) Isoclinal folded and foliated limestone and marble (blue-grey). (c) Massive subvertical pelitic schist (pale brown and green) cut by quartz veins - these are extensive throughout the studied region, but especially well preserved along thick sections $(>100 \mathrm{~m}$ ) near the Cango Caves (Section 2).
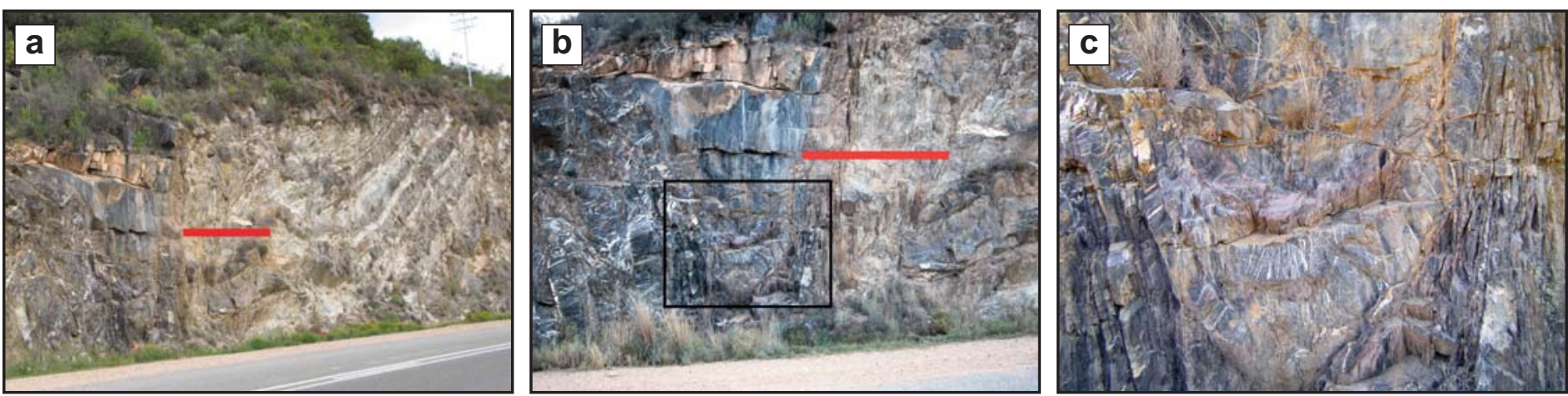

Figure 4C. Typical example of subvertical shear zones separating two different folds styles, both with subvertical axes, in two tectonically separated stratigraphic sequences of the Kango Caves Group. (a, b) Left, grey-blue marble with white calcite veins; and right, shallow dipping pale brown sandstone with minor shale, separated by schist and mylonite (highlighted sections in red) of vertical shear in the lower sequences. (c) Close-up of the subvertical, sub-isoclinal fold of marble in (b) (black outline), with variably angled white calcite veins from axial planar to nearly orthogonal across bedding planes. 

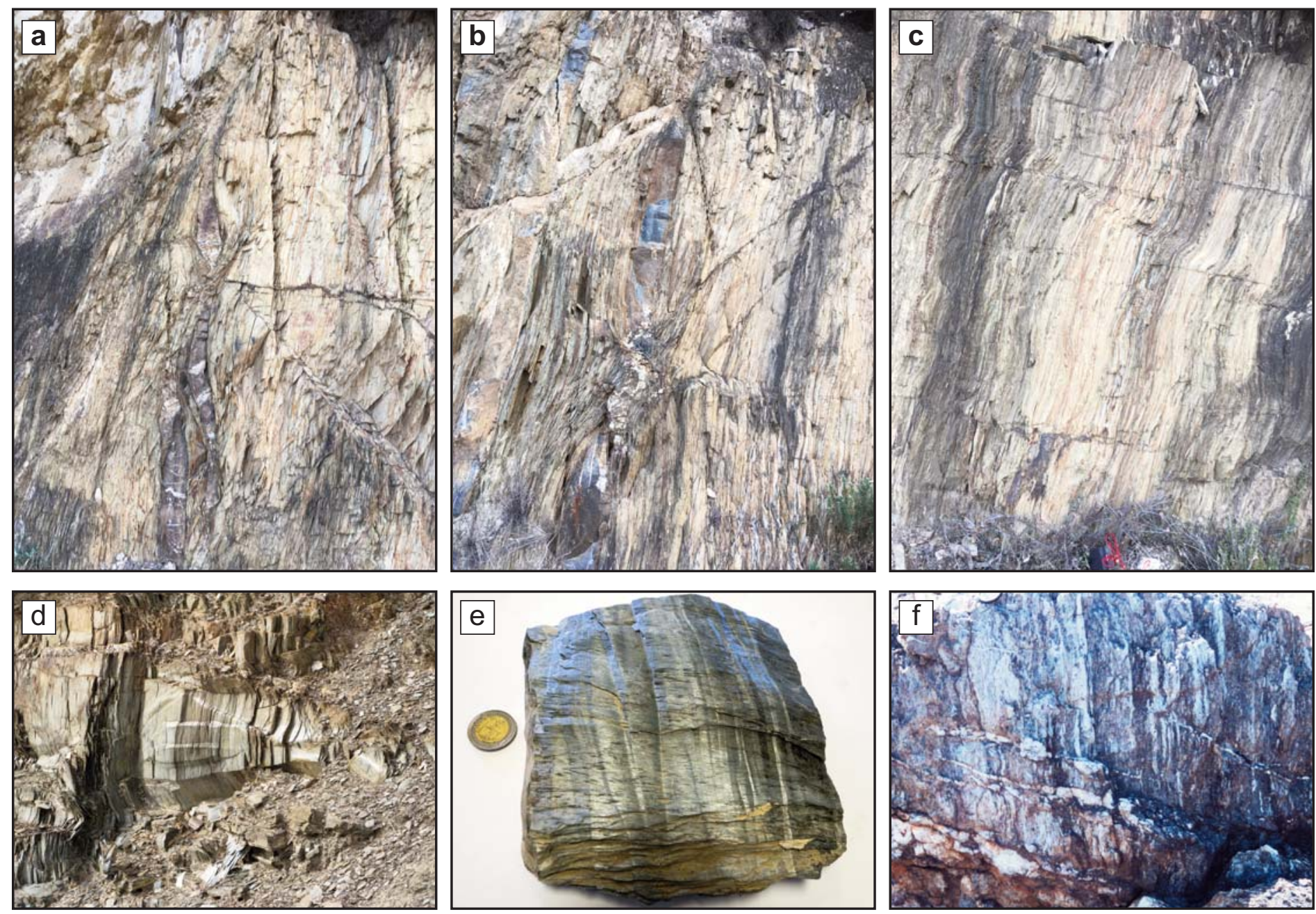

Figure 4D. Typical sections across subvertical mica slate and schist (pale brown) zones (a-c), with folded and boudinaged marble sheets (blue grey with white calcite veins), locally with (d) subhorizontal kinks and vertical tectonic lineations of mica (e) crenulation cleavage (black), and (f) quartz (white). For location a-c see Section 6.
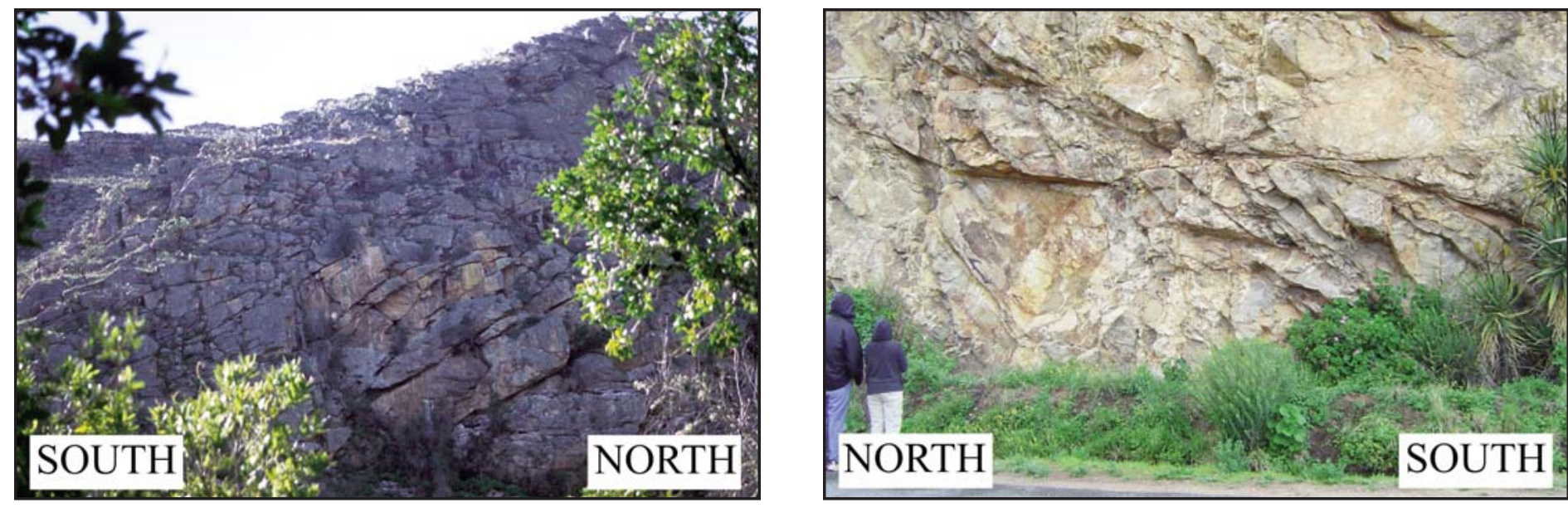

Figure 4E. TMG quartzites flanking the north and south boundaries of the Kango Complex. (Left) North boundary of complex, steep and shallow north-trending thrusts across the contact between the Kango and TMG rocks (Section 11). (Right) South boundary of complex brecciated and brittle thrusts in TMG quartzite at Schoemanspoort near Section 10. 
4D). Thick sequences of K-feldspar-dominated arenite are common, often with large, angular and poorly sorted orthoclase and microcline. Albite-oligoclase plagioclase is less common and always small in grain size. Minor orthopyroxene also has a wide distribution. Zircon, apatite, rutile, epidote and tourmaline make up $95-100 \%$ of the non-opaque heavy minerals, of which zircon is the most abundant. Selected zircon grains from major coarse, poorly sorted feldspar-quartz sandstones in the lowermost sections of the Nooitgedacht Formation, in places directly flanking the Cango Caves to the south (pale brown in Map 1), have been dated between ca. 1377 and $1090 \mathrm{Ma}$ (Barnett et al. 1997; Naidoo et al. 2013).

Between these coarse arenite (and local slate) units of the Nooitgedacht and the Kombuis formations, are the thick sequences of massive Cango Caves carbonate layers and lenses (commonly referred to as limestone - e.g. Stocken 1954; Naidoo et al. 2013; Nel et al. 2018). These are dark grey, with numerous folded and boudinaged calcite-quartz veins (Section 1). The clastic nature of the limestone is evident from the ubiquitous presence of detrital limestone fragments and clasts, calcite grains, ooids and variable concentrations of quartz and feldspar grains in the more arenaceous carbonate rocks. In many places, carbonate sandstones and conglomerates, grading to large boulders, represent complex deposition processes (Sections 2-4 and 7).

The oldest preserved Cango strata comprise variable conglomerates and sandstones that contain poorly sorted pebbles of granitoid gneiss and pegmatite interlayered with unsorted carbonate and quartzite clasts that range from centimetres to several metres in size, commonly with local unconformities and disconformities (Section 3; see also Nel et al. 2018). The characteristic mineralogy and clast lithologies attest to limited transport from the eroded sources and conditions favourable to the preservation of the feldspar. This suggests erosion of a granitic terrane adjacent to a sea or lake with limited reworking, and/or cold, possibly subglacial conditions.

Thus, while the uppermost conglomerate beds across the Kango Complex (Kansa Group) are predominantly well-sorted quartzite with well-rounded granite boulders interbedded with cross-bedded sandstone, the top and bottom of the Cango carbonate sequences are characterized by poorly sorted carbonate conglomerate commonly with limestone boulders in excess of $1 \mathrm{~m}$ in diameter.

Mafic dykes are common across the entire Kango Complex, and in most cases are strongly cleaved or schistose (Fig. $5 \mathrm{a})$. The geochemistry of the basaltic andesite has been reported elsewhere (e.g. Barnett et al. 1997; Van Staden et al. 2006; Van Staden 2011); in the western Cango region, they have been dated at ca. $512 \pm 10 \mathrm{Ma}$ (Haas 1998). Felsic dykes (Fig. 5b) have only been encountered in the lowermost sections of the Kango Caves Group (the Nooitgedacht Formation). The REE of the felsic dykes are similar to those of the mafic dykes (Fig. 5c), but their dates, presented here for the first time, are very much older (Section 7).

Tectonic contacts between and within the Kango sequences are common (Fig. 4E and Map 2), and it remains unclear how the different sequences are linked stratigraphical- ly. Below, we first provide an example of a general deformed section across the Cango Caves, followed by detailed analyses across eleven other sections, from the oldest to youngest, which, when linked to published data and the structural analyses reveal that a new stratigraphy is required for the studied region. This we attempt at the end. The locations of all geosections described below are shown on Map 1.

\section{Stratigraphy of Twelve Cross Sections Based on Lithology and Structural Data}

\section{Section 1. Foliated Marbles of the Cango Caves}

Highly deformed carbonate rocks are exposed within the Cango Caves (Fig. 6), here referred to as Cango marbles, and along their contacts with 80-200 m thick pelitic schists.

Good exposures of deformed marble flank the entrance of the caves, along strike below the edge of the car park and along the partly exposed roofs within the caves (Fig. 7). Massive 'limestone' marble with calcite veins and boudins is tectonically foliated. Similar tectonic zones are common in parts of the Kango Caves Group across the entire studied region, but are often difficult to quantify, since the carbonate rocks are usually recrystallized, weathered, and poorly exposed. It is therefore not possible to measure accurately the tectonized sections of the Kango Caves Group (see also Stocken 1954); however deformed carbonate layers and conglomerates (Figs. 7 and 8) confirm extensive deformation throughout the Cango carbonate rocks, including those flanking, and interbedded in the Groenfontein Formation (Section 9).

\section{Section 2. Conglomerates and Phyllites Along the Road to the Cango Caves}

To the south, the Cango limestone is flanked by boulder conglomerates and phyllites of the Nooitgedacht Formation, more than $500 \mathrm{~m}$ across (Fig. 8). The contact is a fault zone with $80 \mathrm{~m}$ thick green fine-grained phyllite to schist locally with sandstone interbeds with some preserved crossbedding that indicates younging directions to the south. This road section cuts across thick bedded conglomerate and coarse sandstone, in total $40 \mathrm{~m}$ thick, younging north, in the opposite direction, highlighting a tectonic boundary. The conglomerate is clast-supported, with angular to sub-rounded pebbles of granite pegmatite, granite gneiss, with coarse blue quartz and white feldspar matrix, and rounded, poorly sorted boulders of carbonate between 0.1 and $3 \mathrm{~m}$ in diameter (Fig. 9A). These lithologies reveal the relative proximity of two distinct sources: first from coarse-grained granite and pegmatite intrusions, and second from carbonate platforms from which exotic limestone blocks were derived. The limestone boulders resemble 'megabreccia' beds of the Cow Head Group, western Newfoundland, deposited as talus sediments (e.g. Hiscott and James 1985; James and Stevens 1986). Such a process of rapid, catastrophic deposition indicates a high topography such as along continental slopes and submarine escarpments (Coniglio and Dix 1992; Ager 1992).

Well-exposed outcrops along the road reveal multiple unconformities and anticlinal structures plunging southwest 

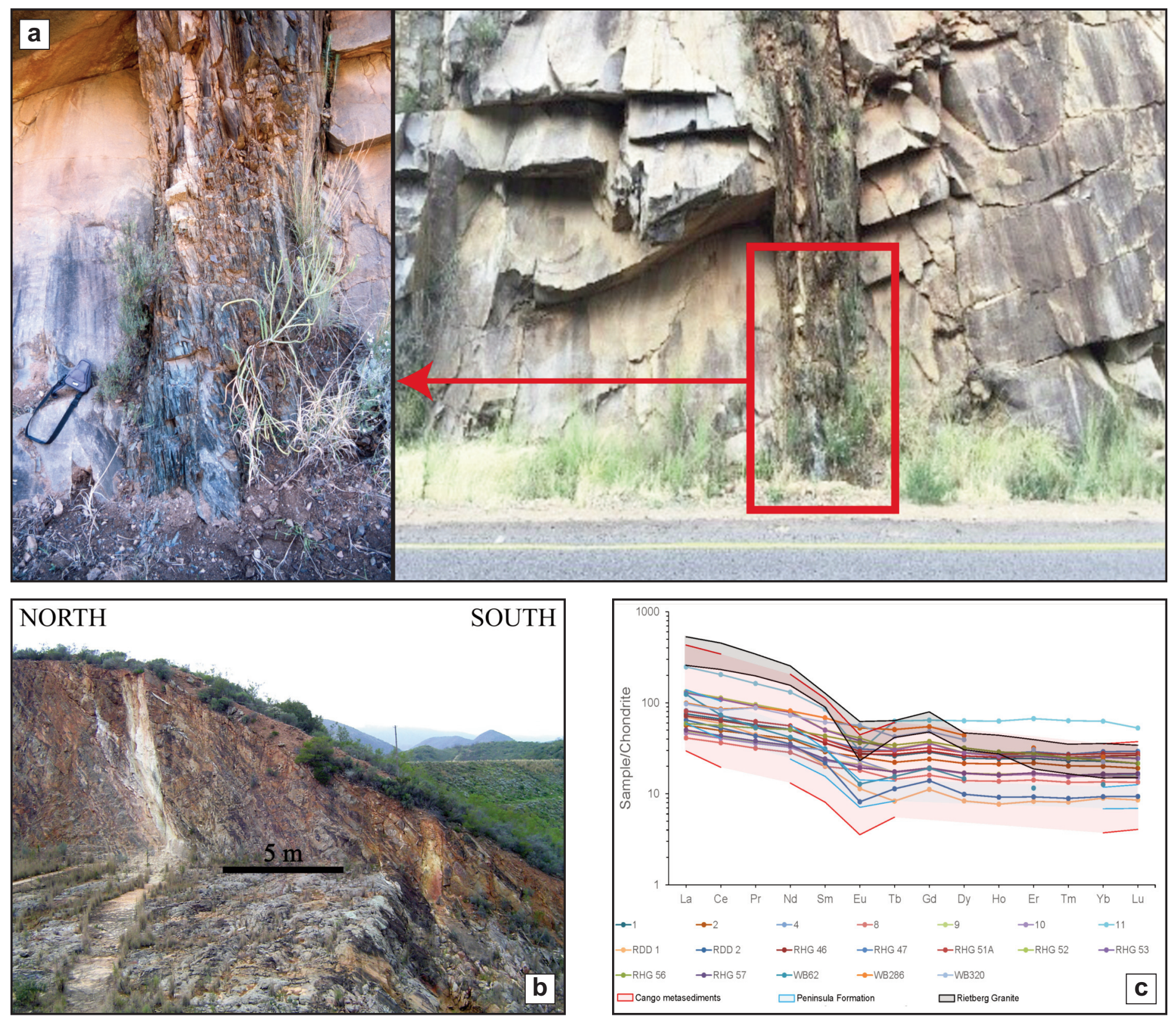

Figure 5. (a) Typical green schistose dolerite dyke (vertical) with extended quartz veins intruding poorly deformed quartz-dominated sandstone (subhorizontally bedded) of the Vaartwell Formation along the Schoemanspoort road (Section 10). Igneous zircon grains from this and similar dykes date between 550 and $450 \mathrm{Ma}$ (see text); the geochemistry of the dykes is typical basaltic-andesitic. (b) White, fine-grained schistose and weathered silicic dykes intruding south-dipping sandstone of the lowest exposed sequence (Nooitgedacht Formation) of the Kango Caves Group. U-Pb-dated zircon grains are older than $1000 \mathrm{Ma}$; the geochemistry of these dykes is andesitic. (c) Normalized rare earth elements for rock samples of the Kango Complex compared to data from Macey et al. (2018; the Rietberg Granite dated at 1033-1086 Ma) and Naidoo et al. (2013; the Cango and Peninsula sedimentary rocks).

(N275). Boulder conglomerate (40 m thick) is clast- to matrixsupported, with angular to sub-rounded pebbles and large blocks of carbonate, feldspar, pegmatite and blue quartz (Figs. 8 and 9B). It is overlain by carbonate schist, phyllite and again boulder conglomerate but with larger blocks (1-3 m), although it is not clear if these beds are repeated.

The good outcrops exposed farther down along the road show several unconformities (Fig. 10). Although grading and cross-lamination of sandstone interbeds within the phyllite indicates younging directions to the south, it is not clear if the succession is repeated more than once. Southward the boulder conglomerate becomes thicker ( $80 \mathrm{~m}$ thick) with larger limestone boulders up to $3 \mathrm{~m}$ in diameter. Large quartz veins cut across this sequence (Fig. 8).

\section{Section 3. Massive Sandstones, Clastic-Carbonate Rocks and Boulder Beds Between Groenfontein and Grootkraal}

A $2 \mathrm{~km}$ long, north-south cross-section is described flanking the valley between Groenfontein and Grootkraal (Figs. 11 and 


\section{SOUTH}

\section{NORTH}

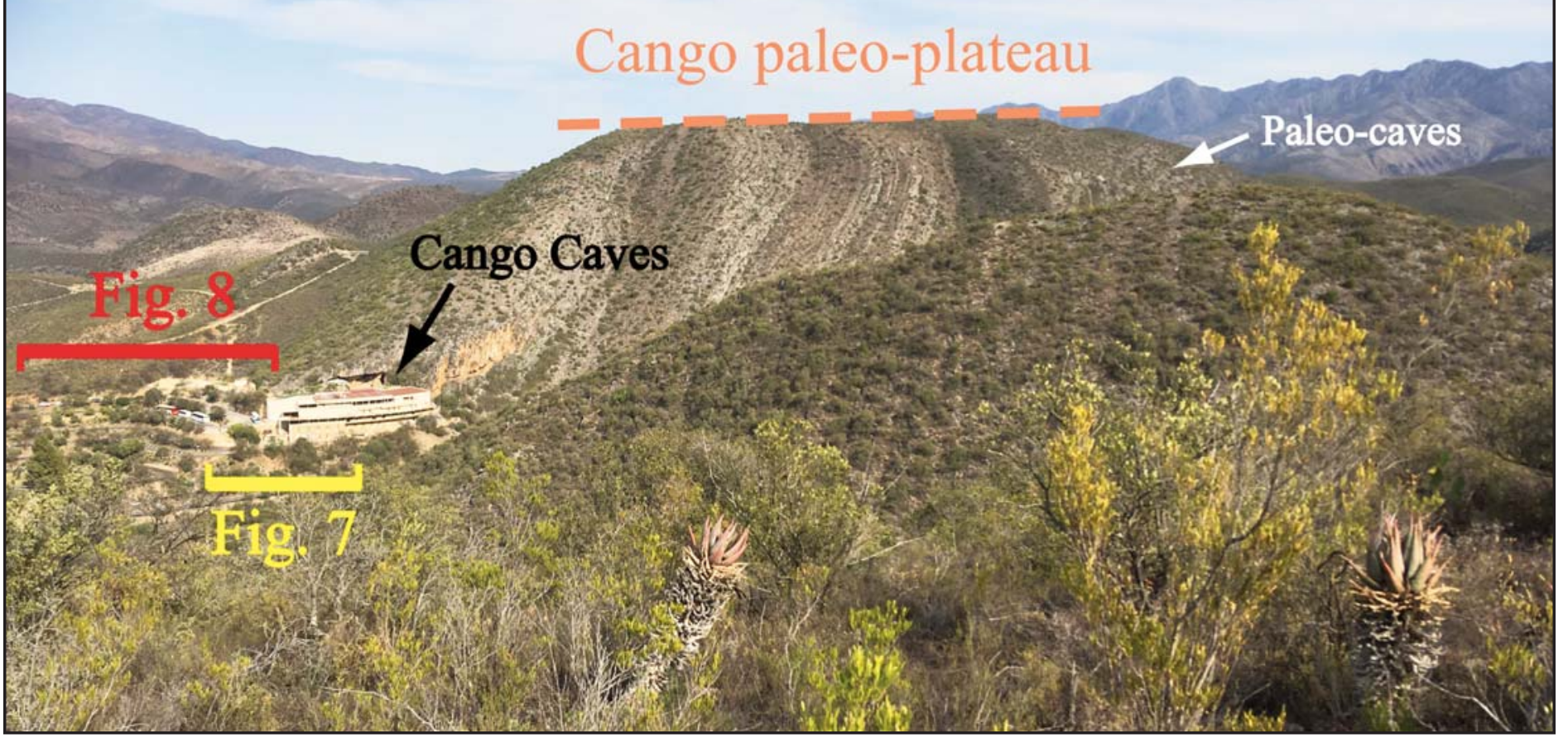

Figure 6. Westward view across the Cango Valley with generally poorly exposed limestone in the foreground, highlighting the well-exposed steep south-dipping (70-80 ${ }^{\circ}$ interlayered sequences of Cango 'limestones' (pale grey carbonate rocks) and shales (green, and generally covered by vegetation) of the Kombuis Formation (Section 1, Map 1). The famous Cango Caves occur close to the contact between the southernmost carbonate lavers and pelitic schist; here the carbonate rocks are highly deformed (see Figs. 7 and 8). Paleocaves and sinkholes are also preserved along the northern boundary of the carbonate with overlying turbidites of the Groenfontein Formation; for all cave locations see Map 2

12). Linked to north-younging Cango massive limestones and carbonate conglomerates of the Kombuis Formation along its tectonic contact with the Groenfontein Formation, is a large syncline-anticline fold pair of coarse feldspathic sandstones, thick sequences of phyllite, and clastic-carbonate rocks with boulder beds (the Nooitgedacht Formation; Fig. 3).

These rocks are deformed along tight, axially subvertical folds (Figs. 13 and 14A), and it is not clear how much stratigraphic thickness is missing along the tectonic zone that separates the phyllites from the feldspathic sandstones, and particularly across the tectonically thinned carbonate layers flanking the southern part of the cross-section (Fig. 12). A change in bedding directions across a subvertical cleavage confirms large $(0.5-1 \mathrm{~km})$ anticlinal and synclinal structures.

To the south, more abundant green phyllites and massive carbonates terminate with $10 \mathrm{~cm}$ to $2 \mathrm{~m}$-thick clastic-carbonate pebble beds that alternate with fine and coarse-grained limestone, with sharp laminations, cross-stratifications and relatively abundant soft-sediment deformation structures, characteristic of turbidites. All reveal younging directions to the south (Fig. 14B). Near Grootkraal Farm, this succession is 125 $\mathrm{m}$ thick, bounded by a subvertical slate shear zone (Fig. 13). Bedding becomes progressively thicker upward to the south and passes up into carbonate conglomerate beds (with subangular to well-rounded boulders), 0.5-5 $\mathrm{m}$ thick, separated by sandstone layers (Fig. 14C). Truncations at the bases of some of the beds (Fig. 14D) suggest that the general southward coarsening and thickening trend of this prograding sequence results from gravity flows. These are interpreted as oligomictic debrites (breccia flows) derived from slope failure, with the large clasts supported by the bulk density of the flow (e.g. Coniglio and Dix 1992).

The outcrop of these carbonate conglomerate sequences has been interpreted previously as a north-younging inverted paleo-valley (Nel et al. 2018; see their figure10). The different sedimentary structures described here are not consistent with this interpretation (Fig. 14B-D). This suggests similar depositional conditions, albeit more distal to the boulder conglomerates described along the road flanking the Cango Caves (compare to Fig. 8).

\section{Section 4. Phyllites and clastic-carbonate rocks of Koos Raubenheimer Dam}

Farther east, along the banks of Koos Raubenheimer Dam (Fig. 15), massive sequences of clastic-carbonate rocks and siltstones to mudstones of the Matjiesrivier Formation are well exposed especially during low rainfall years. The beds young and dip between 50 and $80^{\circ}$ north.

Along the western section (Fig. 16A), subvertical conglomerate and coarse sandstone $\left(115 / 80^{\circ} \mathrm{N}\right.$, overturned; $170 \mathrm{~m}$ thick) are sharply overlain by more than $100 \mathrm{~m}$ thick clastic limestones. The contact between the two sequences is folded 

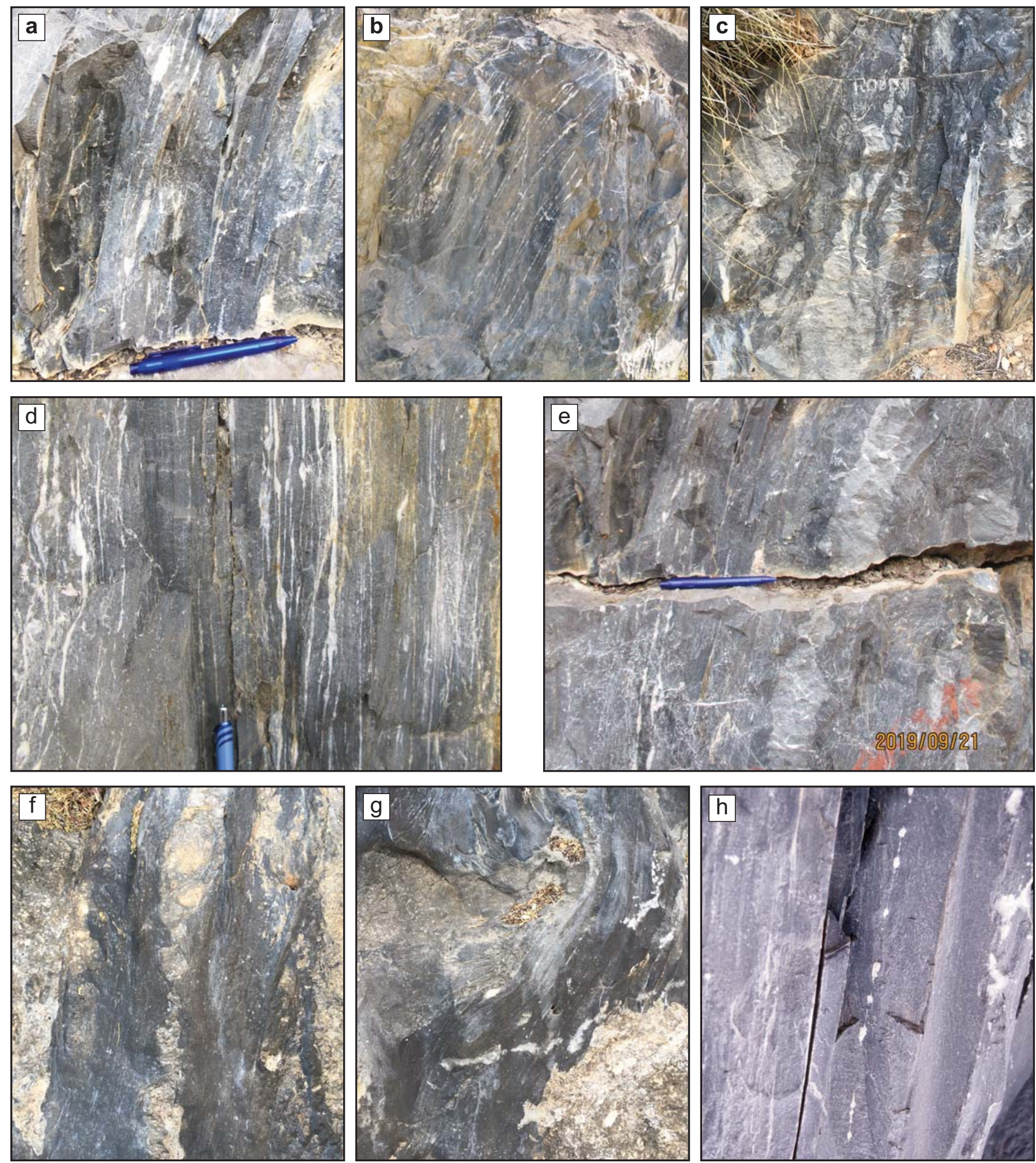

Figure 7. Foliated Cango Caves marbles with quartz-calcite veins and boudins of distinct carbonate members. Many sections like these occur throughout the Cango limestone units, separated by less deformed sequences. The deformed carbonate rocks are difficult to recognise in the Cango sections, but much of the limestone in the caves is part of these intensely deformed sections, and it remains uncertain how to stratigraphically separate the deformed and undeformed limestone/marble sequences. Top photos are from the car park below the entrance to the Cango Caves (Fig. 6); middle photos are from along the road section (Fig. 8); and bottom photos are from along the western Rauberheimer Dam (Section 4).

14. http://www.geosciencecanada.ca 

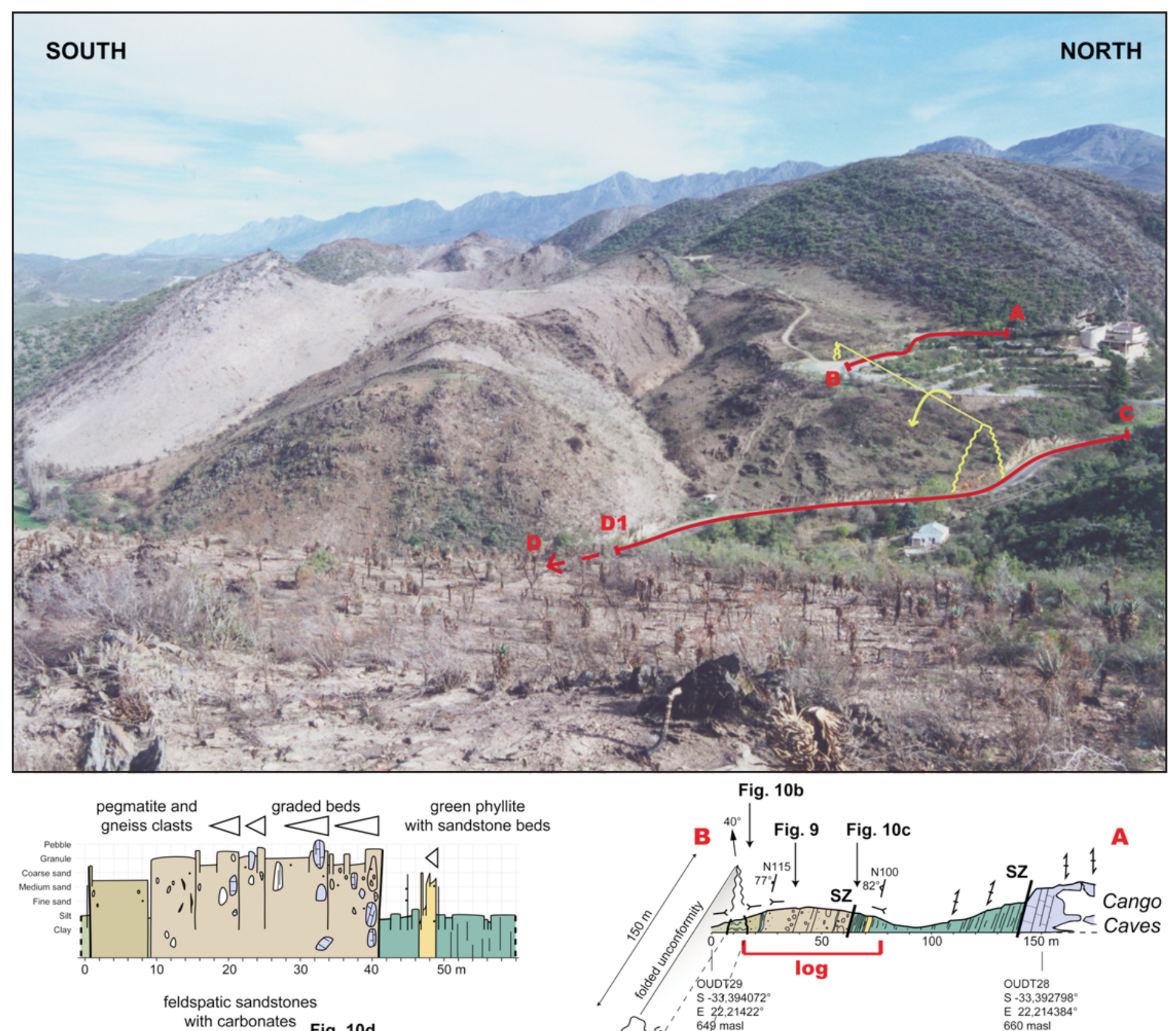

Fig. 10b

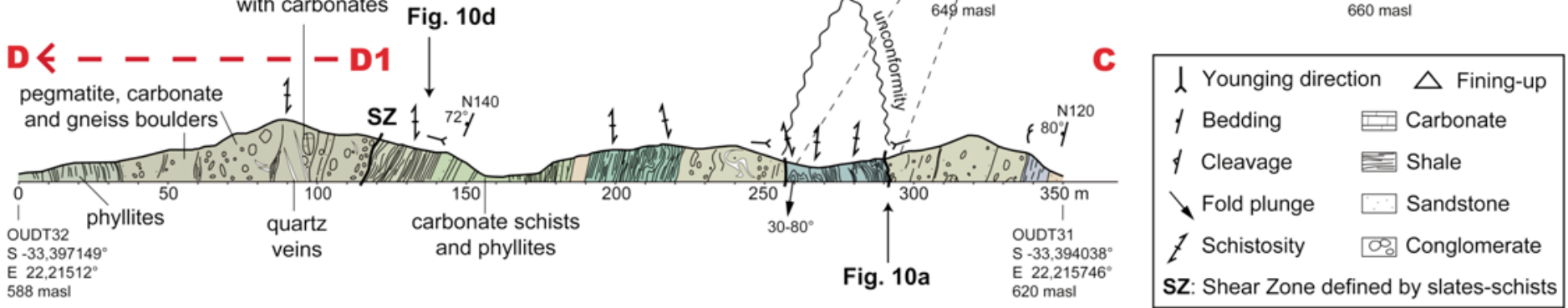

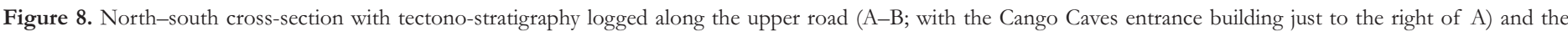

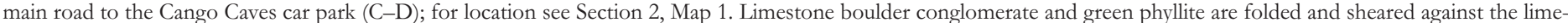
stone-marble of the Cango Caves (the Kombuis Formation). 

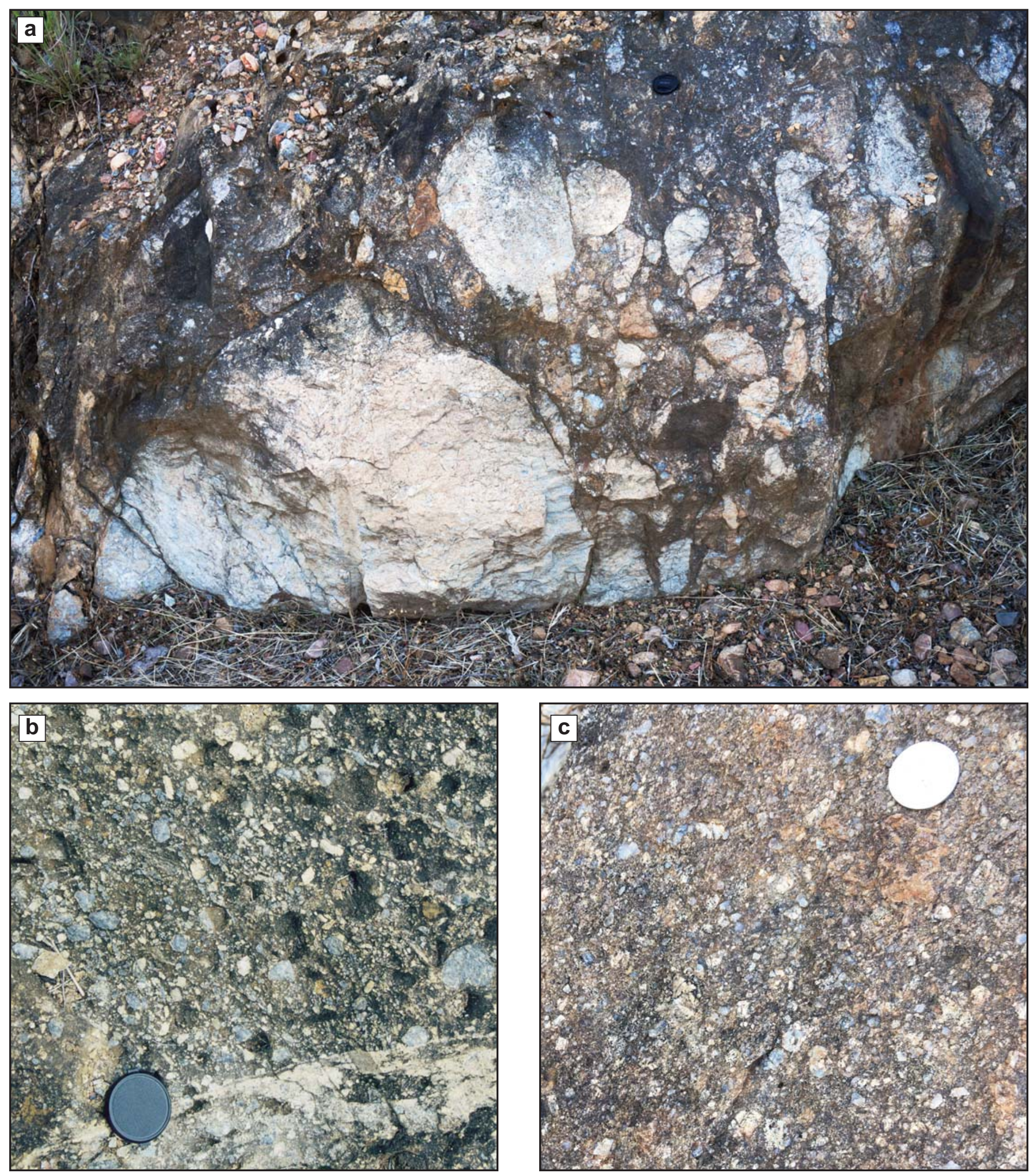

Figure 9A. (a) Graded bed of carbonate pebbles to boulders with angular to well-rounded clast- and matrix-supported pebbles of pegmatite and gneiss in feldspar-quartz matrix (Fig. 8 for location). (b-c) Typical coarse, poorly to well-sorted sandstone to grit with single white crystal K-Na plagioclase feldspars and blue quartz in the Nooitgedacht Formation. U-Pb geochronology of detrital zircons from the sandstone yielded Mesoproterozoic ${ }^{206} \mathrm{~Pb} /{ }^{238} \mathrm{U}$ dates between 1200 and $1050 \mathrm{Ma}(\mathrm{Barnett}$ et al. 1997).

1) http://www.geosciencecanada.ca 

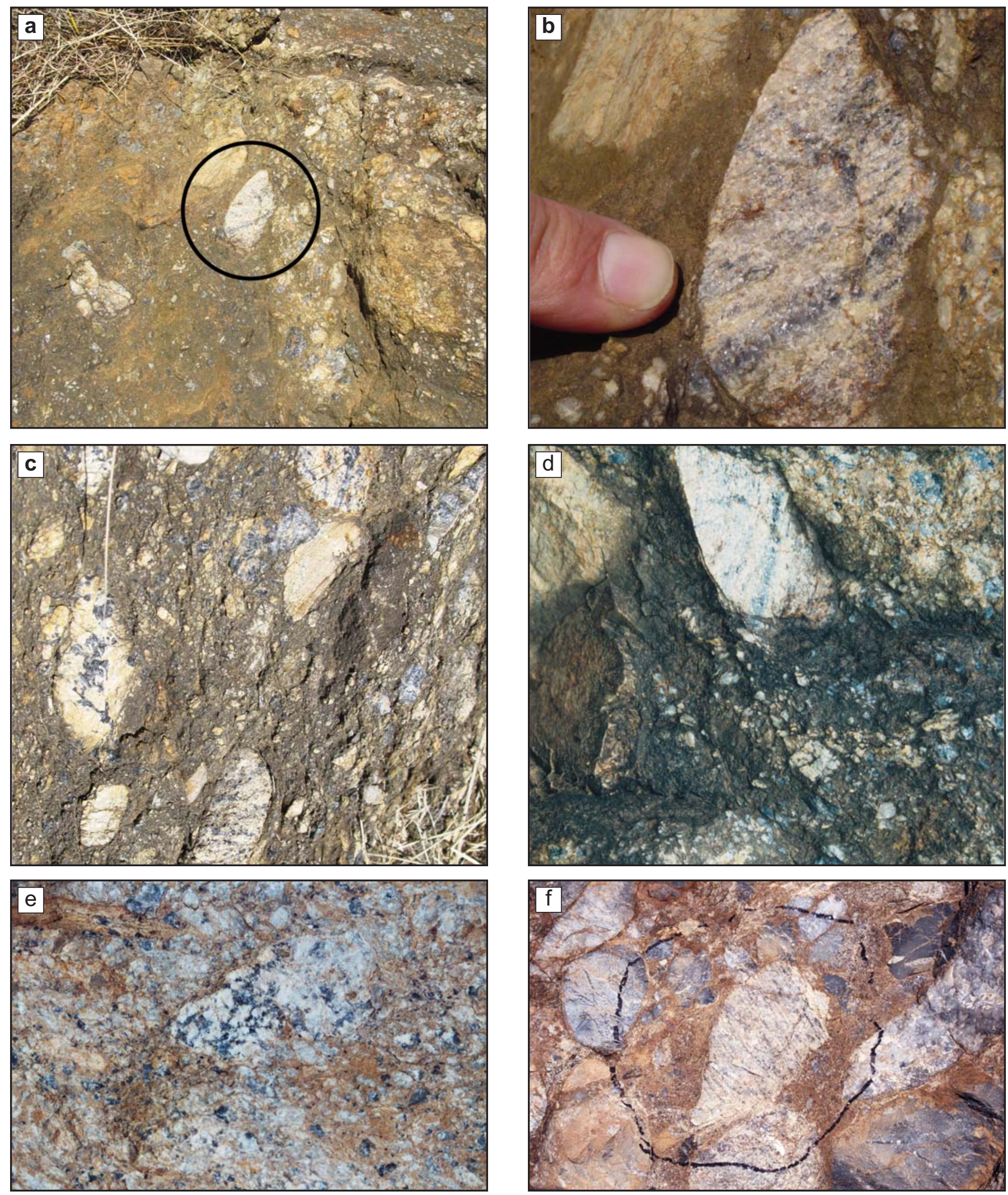

Figure 9B. Angular to well-rounded and matrix-supported small pebbles $(3-7 \mathrm{~cm}$ long) of pegmatite and granite gneiss in feldspar-quartz matrix (Fig. 8 for location). 

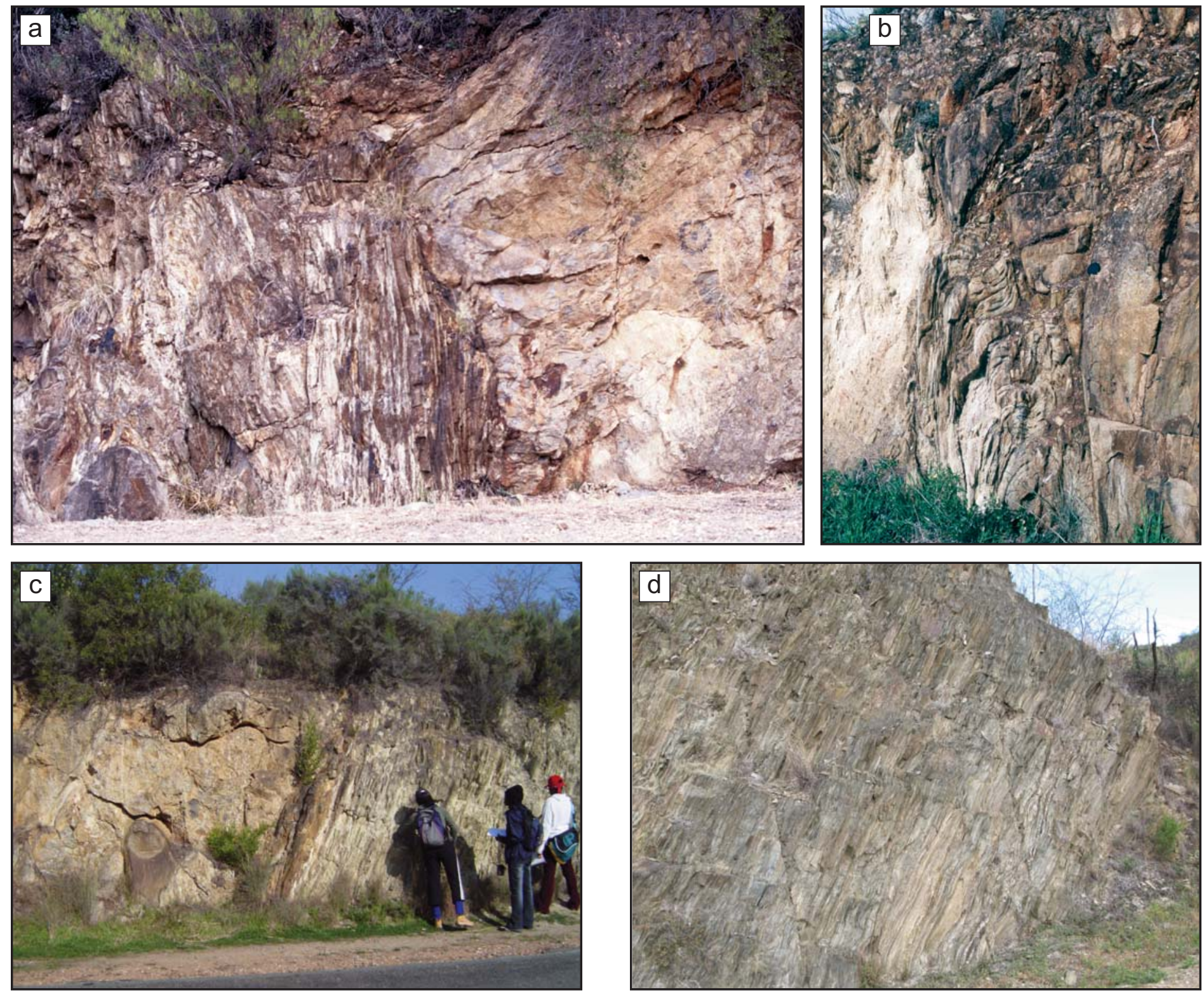

Figure 10. (a, bottom road, and b, top road) Unconformable contacts between thin bedded shale (left) and thick conglomerate-sandstone (right). (c) Tectonic contact between conglomerate-sandstone and phyllite, with (d) close-up of phyllite behind students. For locations a-c, see Figure 8.

and reprecipitated carbonate about $3 \mathrm{~m}$ thick. The lower conglomerate is composed of clast-supported small pebbles of feldspar and black quartz, grading into sandstone and shale, which suggests a younging direction to the north. Overlying sandstone comprises pebbly to very coarse-grained beds with shale interbeds that have a cleavage of direction N275.

The clastic-carbonate rocks are thinly to thickly bedded, between 0.3 and $3 \mathrm{~m}$, with matrix-supported clasts showing normal and reverse grading and passing gradually into fine sandstone and shale to the north (Fig. 16A). The clasts are mostly small sub-angular limestone pebbles and granules of quartz, and occasionally limestone boulders. This characteristic diamictite facies indicates sediment gravity flow.

Along the eastern section the sequences are also near vertical (Fig. 16B). To the south, more than $55 \mathrm{~m}$ of dark grey sandstone is flanked by more deformed clastic-carbonate rocks and shales, in total $420 \mathrm{~m}$ thick. The lower part of this succession comprises $70 \mathrm{~m}$ of bedded limestone with matrixsupported clasts covered by $130 \mathrm{~m}$ of shale with intercalations of coarse sandstone and limestone. Shales show folding and a cleavage direction of N120. The upper part has alternating thin and thick beds of massive limestone with clasts and granules, characteristic of gravity flow and suspension deposits.

Correlations of the Kombuis carbonates across Sections 1, 2 and 3 illustrate a facies changes across ca. $10 \mathrm{~km}$, with more distal slope deposits to the east-southeast (Fig. 17). These are characteristic carbonate slopes, which include different environments from shallow platform margins to the deep ocean basins, with a relatively steep continental slope (Coniglio and Dix 1992). Sediment transport by suspension settling, gravity 


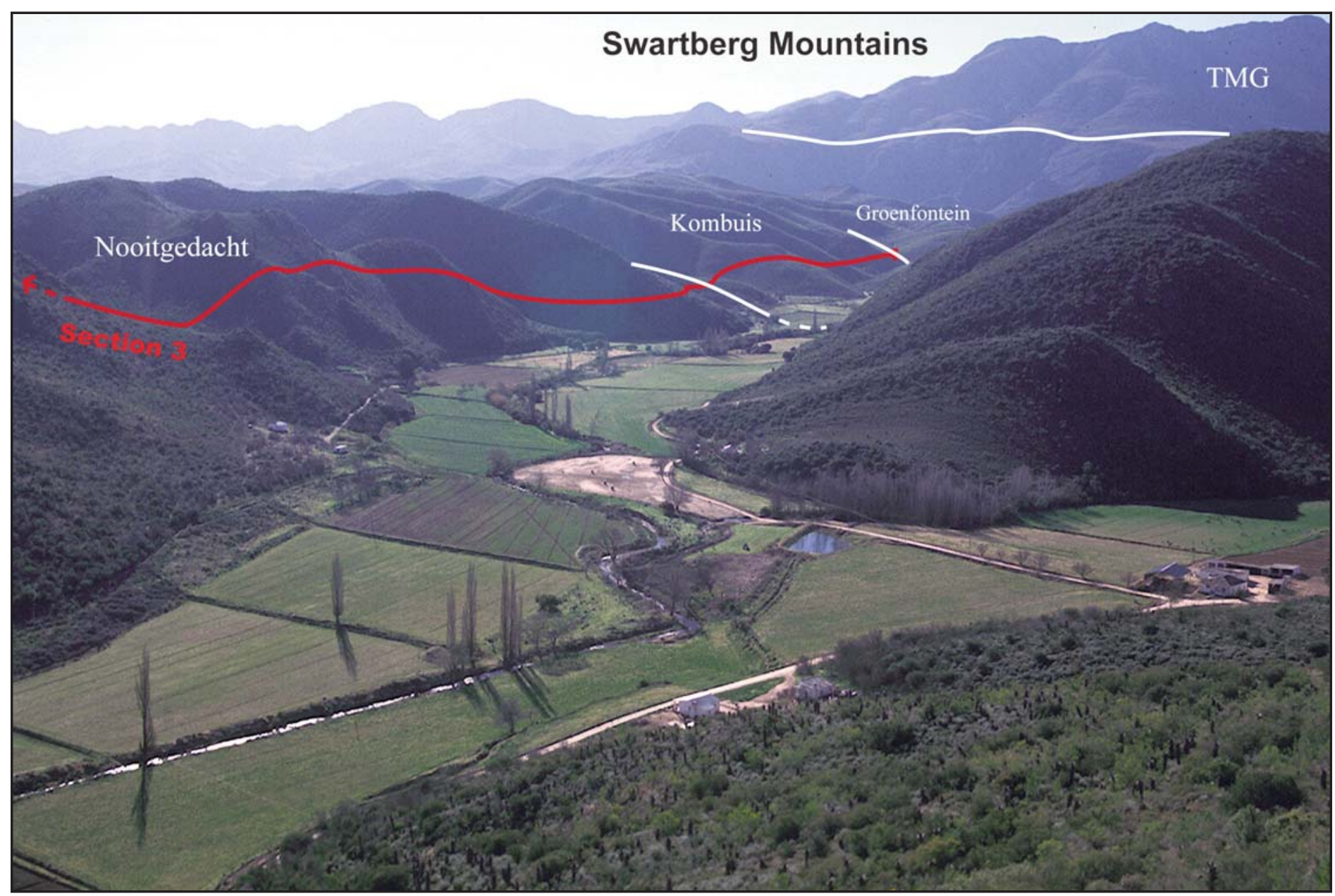

Figure 11. View north towards the Swartberg Mountains along the Tier Berg River showing mapped contacts (white lines) between the Nooitgedacht, Kombuis, Groenfontein and Peninsula formations. Stratigraphic section 3 is described in Figure 12 (Map 1 for location).

(resedimented) flow and submarine sliding often result in interbedded suspension deposits, shale and limestone, turbidites, debrites and contourites. Examples of such preserved stratigraphic records with carbonate boulder beds have been described in detail across the Cow Head Group in the Long Range Peninsula of Newfoundland (e.g. Hiscott and James 1985; James and Stevens 1986).

\section{Section 5. Thrust Fault and Felsic Dykes Along Rauben- heimer Dam Wall}

Along the cut-off wall of the Raubenheimer Dam, south-dipping carbonate rocks and phyllites of the lower Nooitgedacht Formation are tectonically overlain by grey to orange, thickly bedded coarse quartzitic sandstone (grit) intruded by finegrained felsic dykes (Fig. 18). The footwall comprises foliated carbonate rocks with extensional veins and interbedded very fine sandstone and shale. Locally preserved ripple cross-laminations show a younging direction to the south. The tectonic contact is filled with ca. 10-20 cm of schist with folded and duplicated calcite veins that reveal a north-trending thrust zone subparallel to the bedding (Fig. 19).

The new dates of two felsic dykes (Fig. 20) that cut the sandstone (and Cango limestones; see Section 6 below) of the lower Nooitgedacht Formation are similar in age to the ca. 1070 Ma Noritoid Suite in the Nababeep district, the Kopperberg Suite and the Little Namaqualand Suite of the Khoisanland (Bushmanland) subprovince, and in general the Spektakel Suite (ca. $1100 \mathrm{Ma}$ ) and high-grade Namaqualand basement (e.g. Joubert 1986; see also Clifford et al. 1975, 1981; Waters 1990; Eglington 2006). These ages confirm for the first time a much older age for the lower sequences of the Kango Complex.

\section{Section 6. Schists, Thrusts and Felsic Dykes Along the Main Road Near Grootkraal}

Well-exposed subvertical sections (Fig. 21; separated by poor exposures) of phyllite (schist) and psammite with highly deformed limestone lenses ( $\mathrm{A}-\mathrm{ca} .250 \mathrm{~m}$; and separated to the south by $500 \mathrm{~m}$ from schist of Section 9), are separated by about $100 \mathrm{~m}$ from (B) $50 \mathrm{~m}$ of foliated limestone thrusted across phyllite and psammite. Farther inland, the poorly exposed carbonate rocks reveal in places deformed but wellpreserved carbonate conglomerates (Fig. 4B) that confirm their link to the Kango Caves Group, and together with abundant silicic schists likely the Nooitgedacht Formation (Fig. 3). Between outcrops B and C (Fig. 21), the carbonate rocks are 


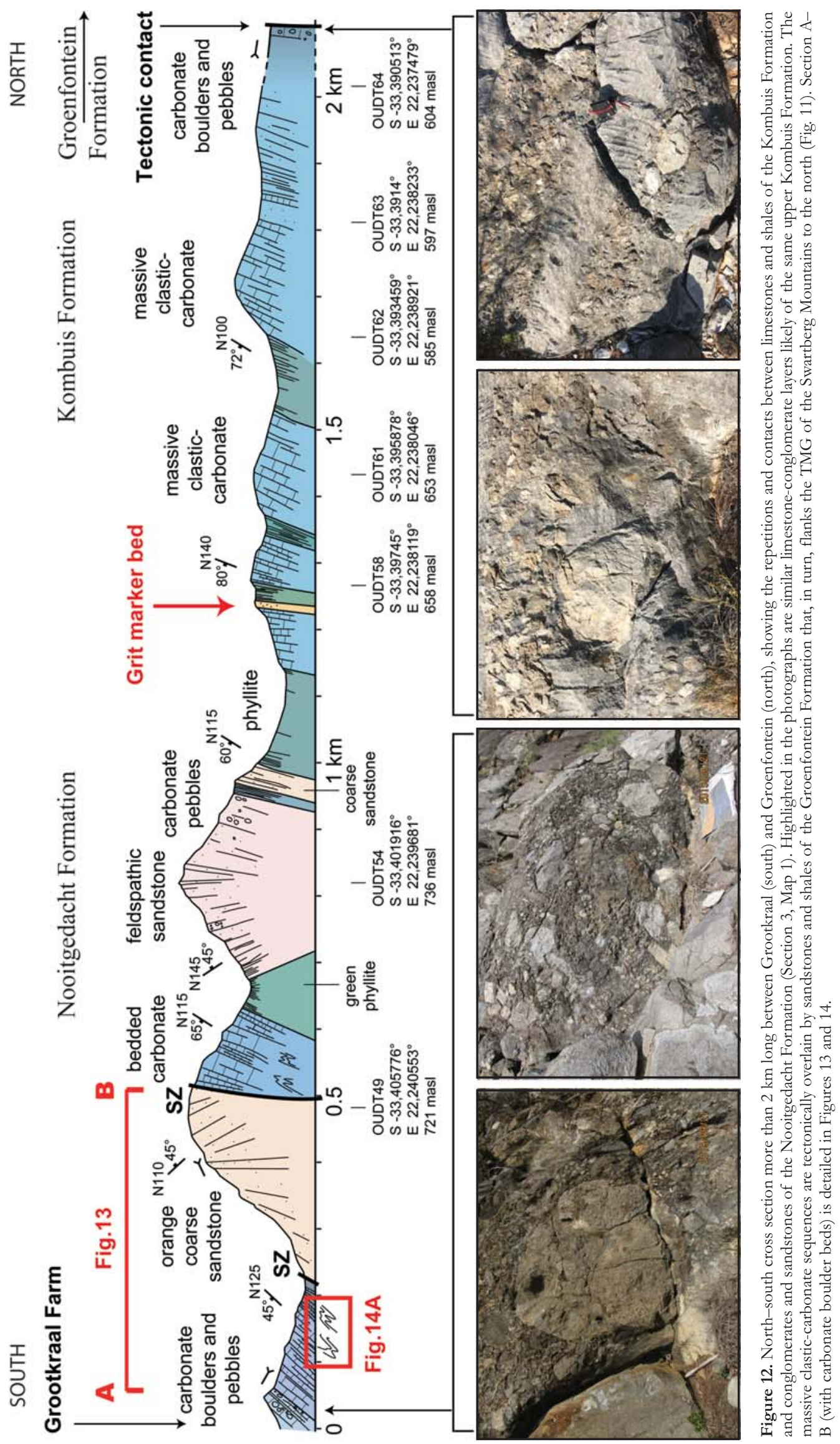



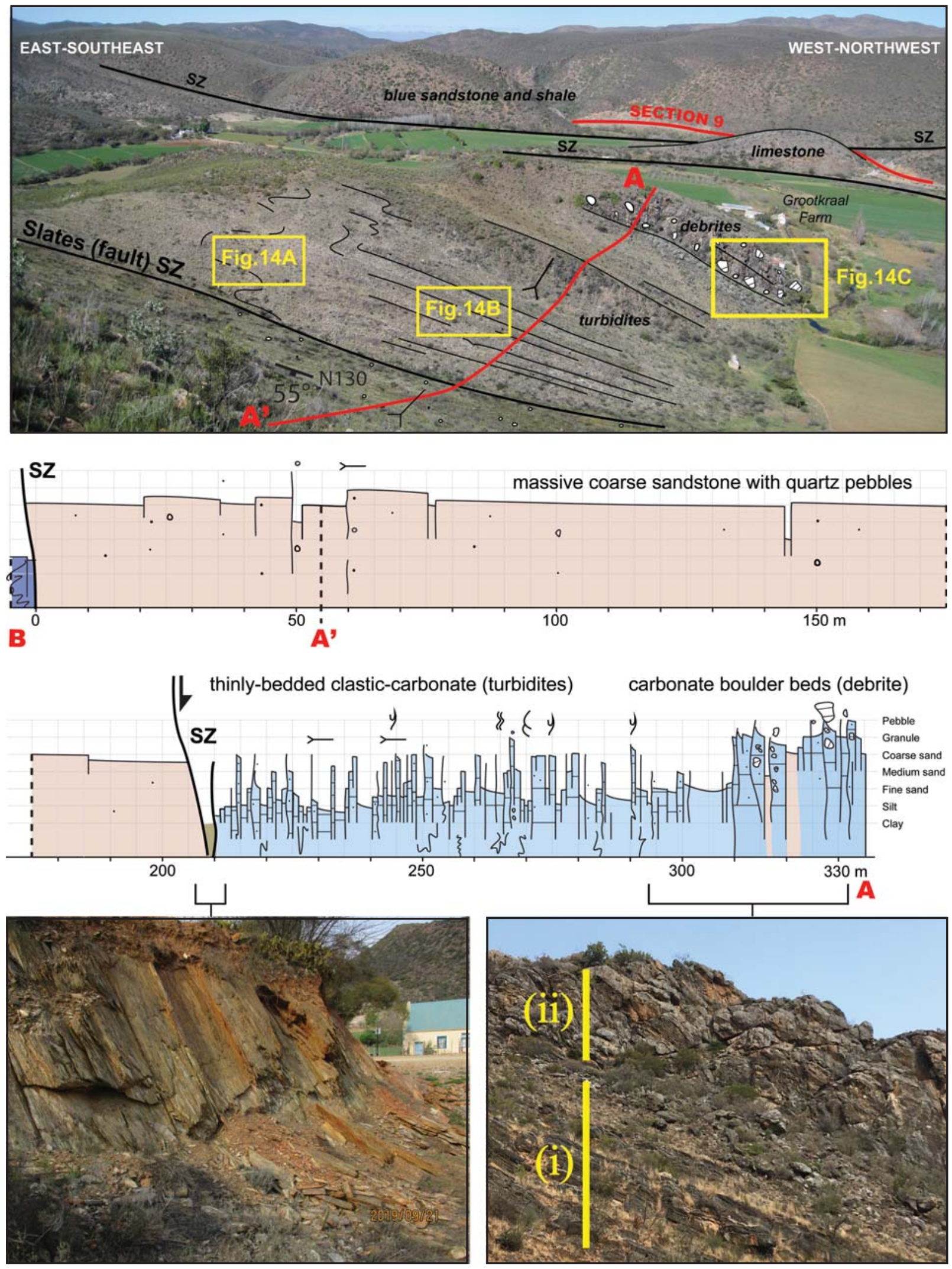

Figure 13. Section across Grootkraal Farm, $125 \mathrm{~m}$ thick clastic-carbonate rocks with sedimentary structures that indicate younging directions to the south, becoming thicker bedded upward and passing into carbonate boulder beds interpreted as turbidites and debrites (Fig. 12 for location). A $50 \mathrm{~m}$ thick schist zone (SZ, bottom left) marks the lower tectonic contact, and in turn is overlain by (bottom right) younging-upward sequences of carbonate turbidites (i) and carbonate boulder and sandstone beds (ii); for detailed outcrops see Figure 14A-D. 

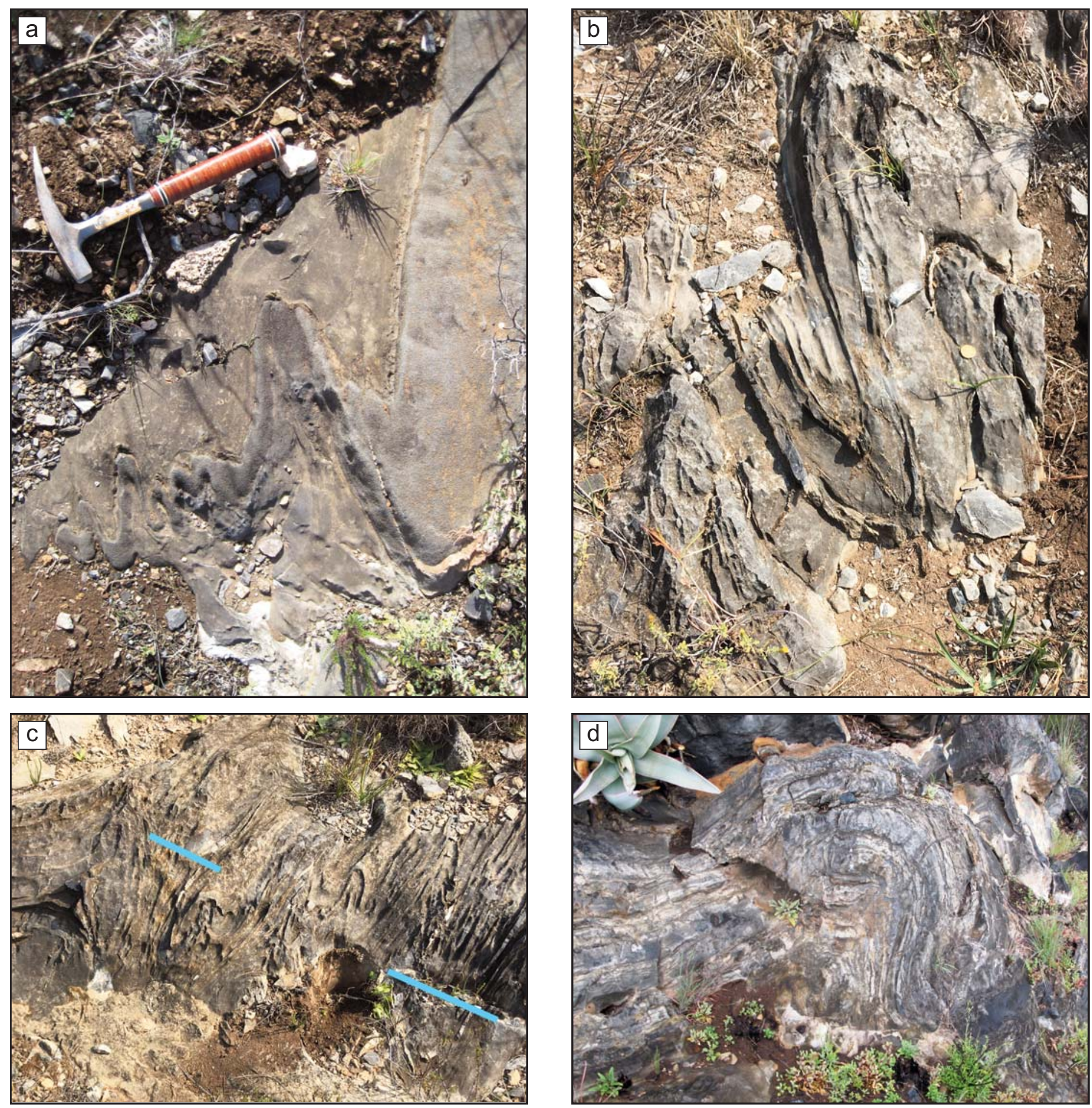

Figure 14A. Examples of steeply plunging folds within the layered clastic-carbonate rocks in the southern part of Section 3 (Fig. 12 for location). (a-b) Open folds without axial planar cleavage; (c) tight folds with variable axial planar shear zones (blue lines); and (d) open fold with folded tectonic calcite zones parallel to bedding that likely represent pre-fold shear zones (compare to Fig. 4A). 

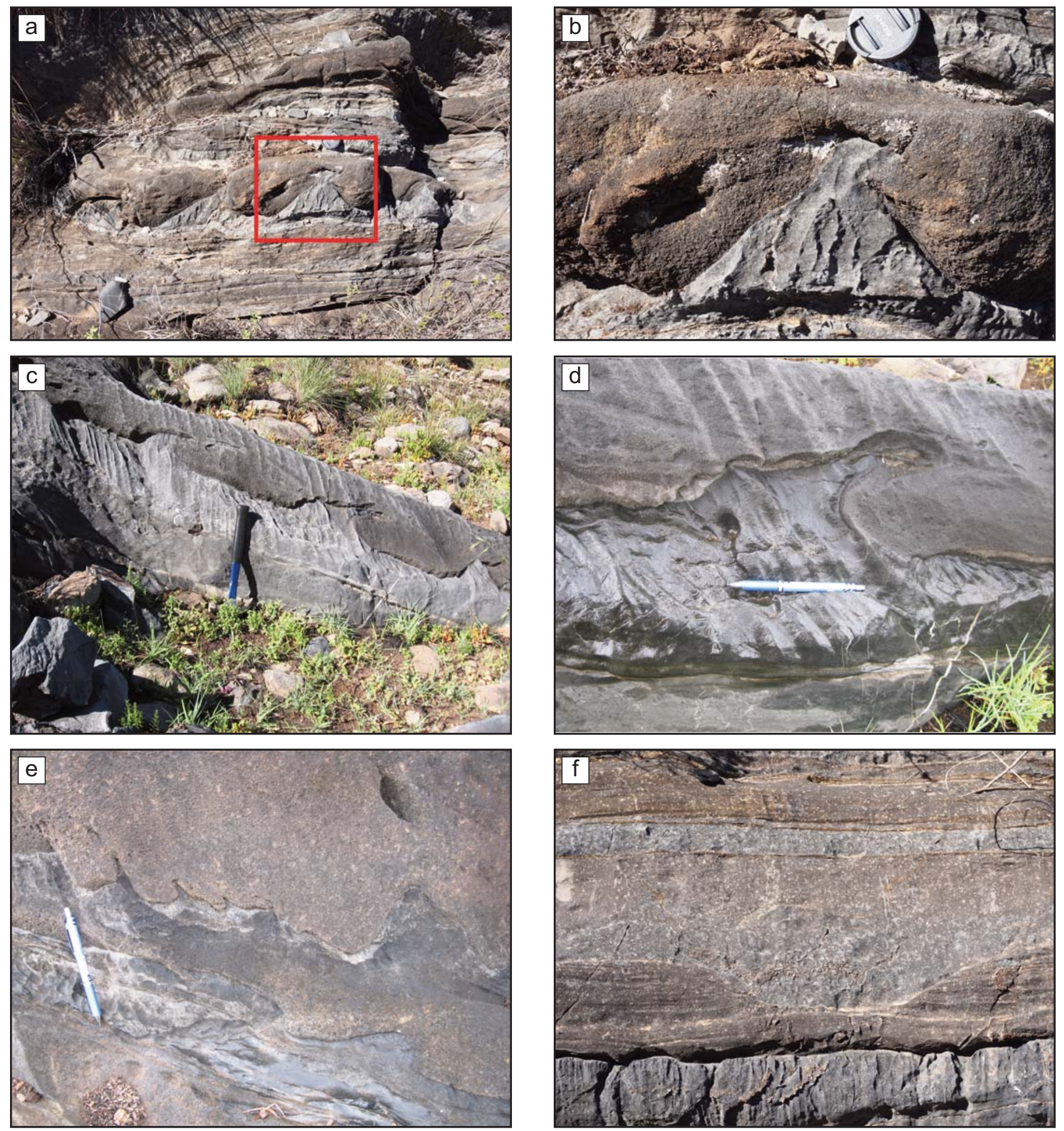

Figure 14B. (a-e) Soft sediment deformation (flame) structures within the limestone turbidites (brown = coarse-grained; grey $=$ fine-grained); and $(\mathrm{f})$ erosion channels $($ contourites). All structures confirm younging directions to the south (Fig. 13 for location). 

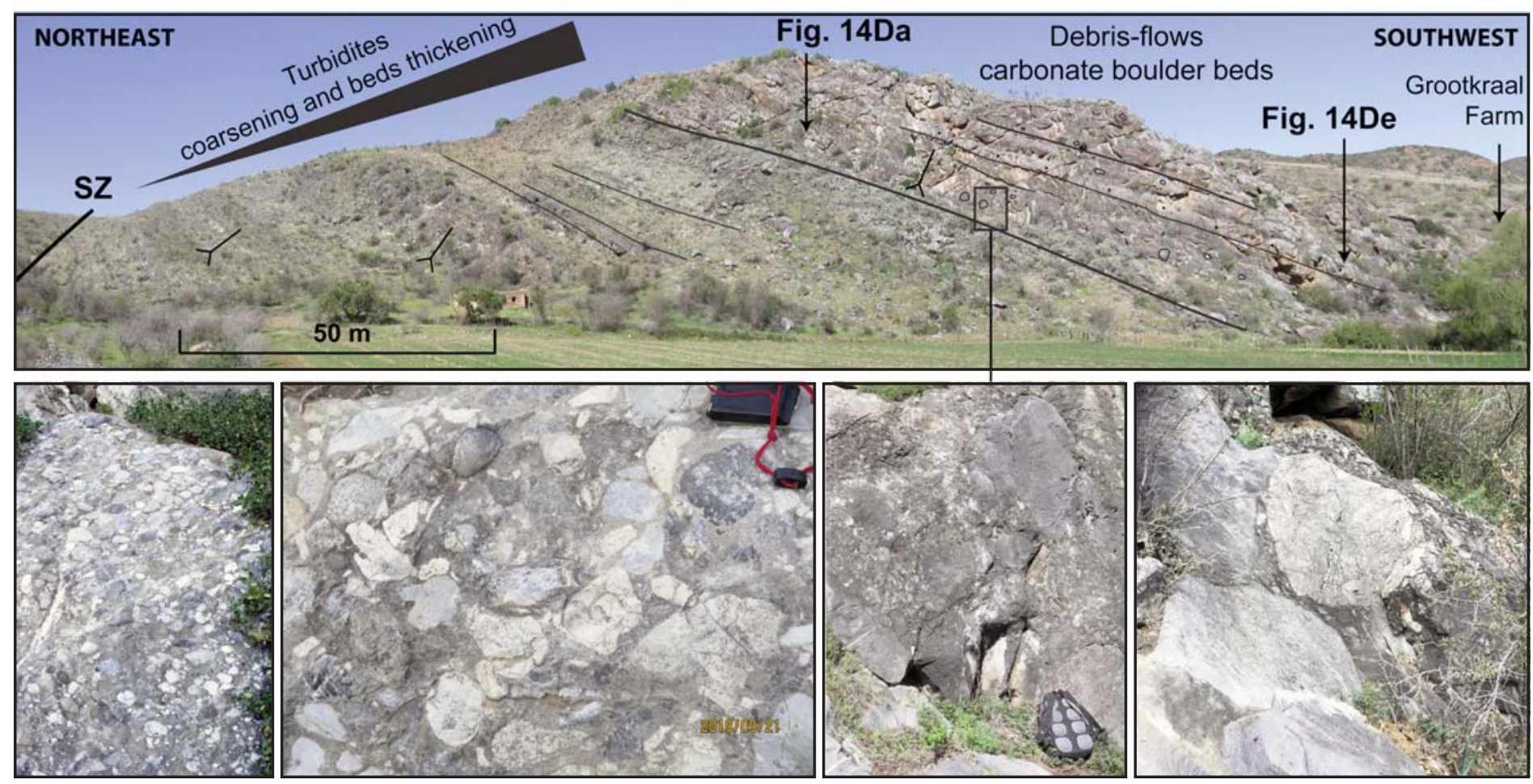

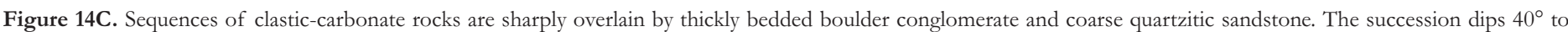
the north and contains erosion surfaces and large rounded to angular limestone boulders interpreted as debris flows.

less foliated and reveal open folding with psammitic layers. At outcrop $\mathrm{C}$, these rocks are intruded by subvertical felsic dykes (Fig. 22A). Zircons from two of these dykes (d1 and $\mathrm{d} 2$ ) yielded a U-Pb date of ca. $1084 \mathrm{Ma}$ (Fig. 22B).

Farther west along the road, this section is structurally overlain by a thick isoclinally folded carbonate-marble sequence (highlighted in Fig. 4C). In detail, this entire section represents part of a highly deformed fold limb of the Kango Caves Group (shortened by at least 60\%; see Map 2), which makes it difficult to separate the Kombuis from the Nooitgedacht formations with confidence.

\section{Section 7. Clastic-Carbonate Rocks at De Hoek Cave}

Thick-bedded limestones within the Groenfontein Formation outcrop at De Hoek Cave (Fig. 23A). These are bluish grey, mud-supported carbonate rocks containing quartz granules and clasts that show both fining and coarsening-upward sequences (Fig. 23B). Rare erosion surfaces indicate a younging direction to the south. The logged section is on the northern limb of an anticlinal structure, unconformably overlying green shale with orange sandstone beds. It comprises $70 \mathrm{~m}$ thick fine-grained limestone overlain by $40 \mathrm{~m}$ thick clastic limestone that become thicker bedded and coarser upward. This succession suggests deposition by filling large channels and progradation.

\section{Section 8. Interbedded Sandstones, Siltstones and Shales of Melville Dam}

At Melville Dam (Fig. 24), interbedded sandstones, siltstones and shales more than $1 \mathrm{~km}$ across are repeated along east-west relatively tight folds plunging south. The sedimentary facies are green to orange, fine to very coarse-grained sandstone beds, $10 \mathrm{~cm}$ to $1 \mathrm{~m}$ in thickness, alternating with siltstone and shale. The fining upward successions of coarse sandstone with erosional bases, passing upward into ripple cross-laminated siltstone and shale are characteristic of turbidites. Preserved groove marks indicate a northwest-southeast transport direction.

\section{Section 9. Thrust Fault and Cross-bedded Sandstones Along the Main Road Near Kombuis}

Flanking the main road near Kombuis (Fig. 25), a major shear zone (Boomplaas Thrust) linked to $70 \mathrm{~m}$ of highly schistose phyllite of the Groenfontein Formation and $70 \mathrm{~m}$ of interlayered limestone/marble and phyllite of the Kombuis Formation, dips $65-80^{\circ}$ south along this fully exposed section. To the north, this schist zone, unexposed for $30 \mathrm{~m}$, links to zones of highly deformed marble boudins in schistose phyllite (described in Section 6). Southward, the shear zone is tectonically overlain by $260 \mathrm{~m}$ thick grey to blue cleaved sandstone, siltstone and greywacke of the Uitvlugt Formation (Fig. 26a) where, across the upper $50 \mathrm{~m}$, the cleavage cuts across bedding of a well-preserved anticline linked southward for $200 \mathrm{~m}$ to separated parts of a highly fragmented synform along schistose phyllite (Fig. 26c).

The sandstone beds are overturned, comprising relatively abundant syn-depositional erosional features that indicate younging directions to the north (Fig. 25). The sedimentary facies include undular and large-scale cross-stratifications, 2$10 \mathrm{~m}$ in width, with mud drapes and rip-up clasts, which indi- 

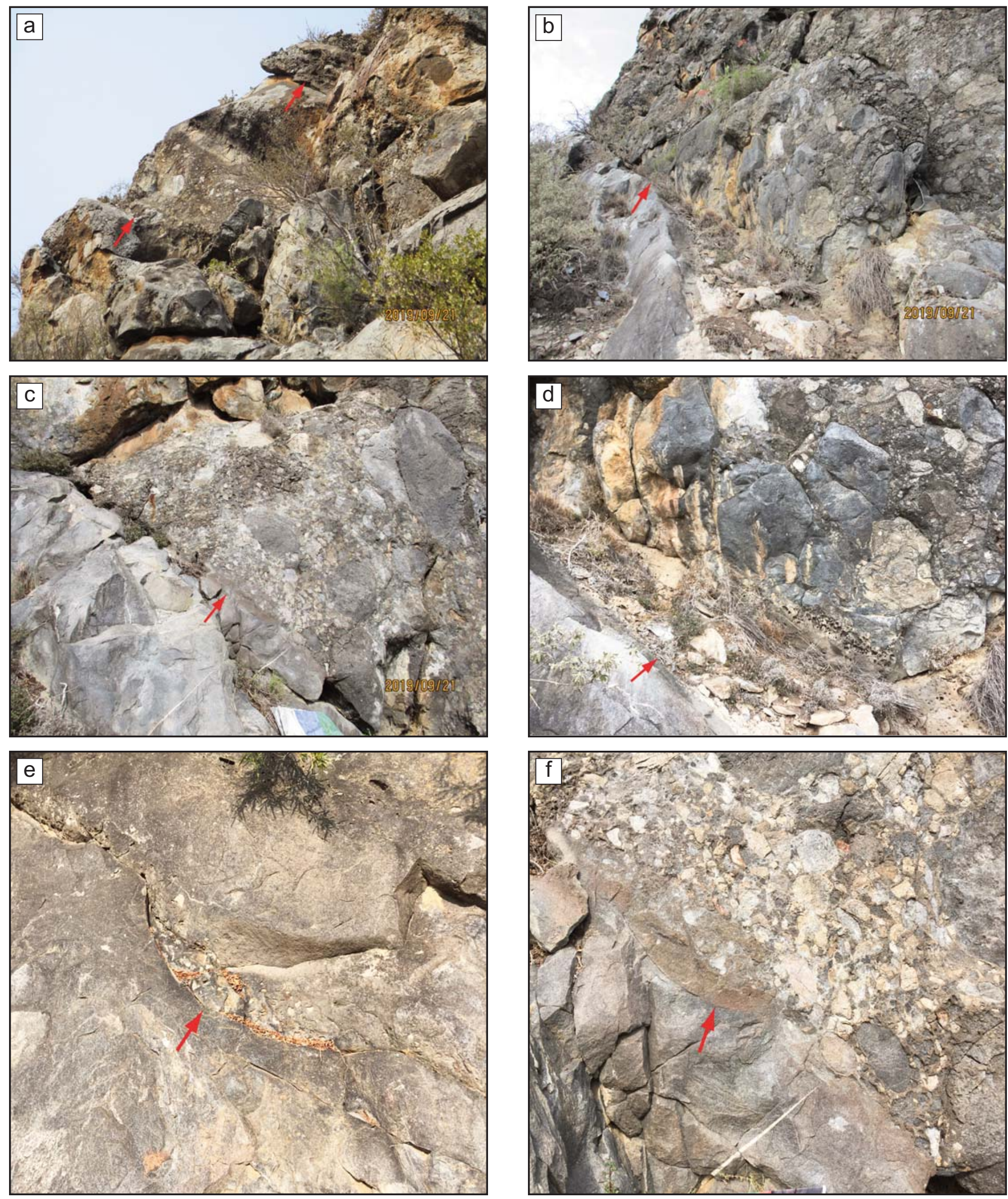

Figure 14D. Erosive contacts (red arrows pointing up) within the carbonate boulder beds indicating younging directions to the south (Fig. 14C for location) 


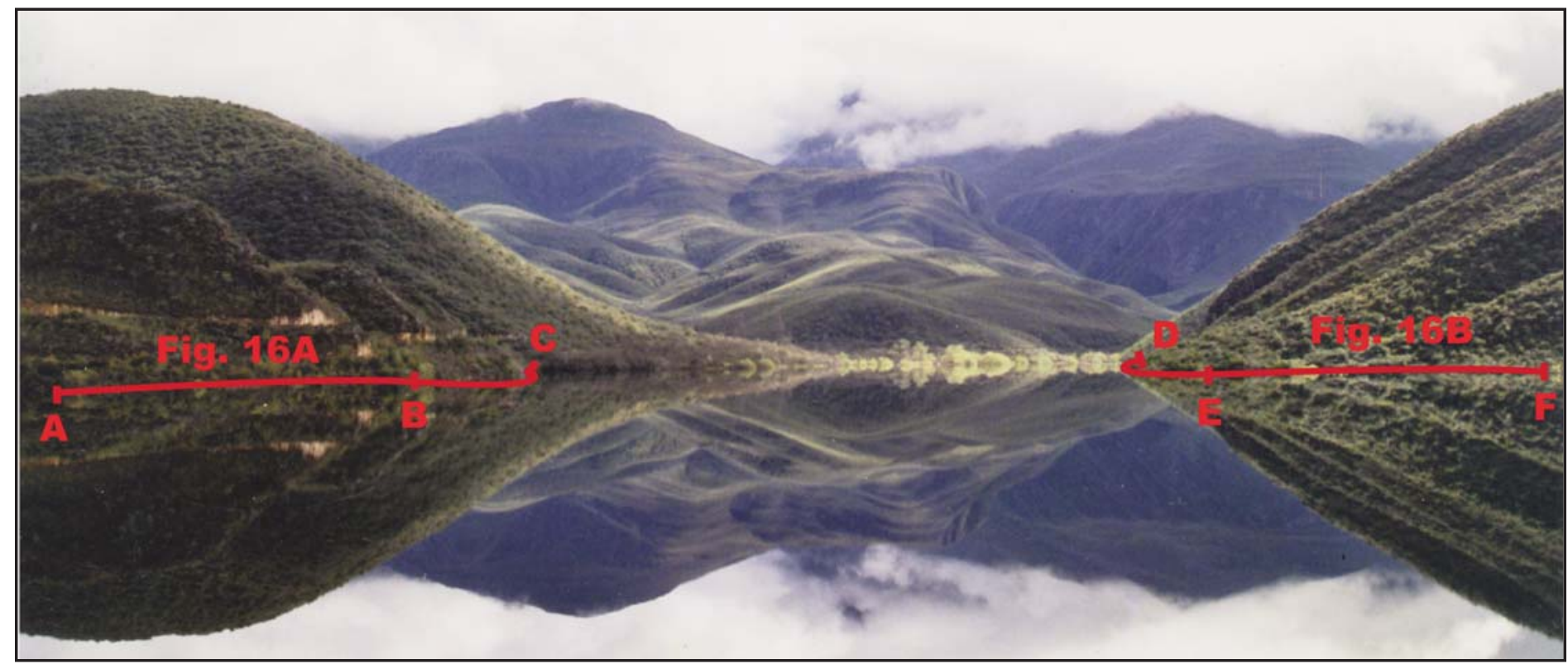

Figure 15. General north-facing view across the lake of Koos Raubenheimer Dam (Section 4, Map 1), showing the location of detailed cross-sections along the western and eastern banks in Figures 16A and 16B, respectively.
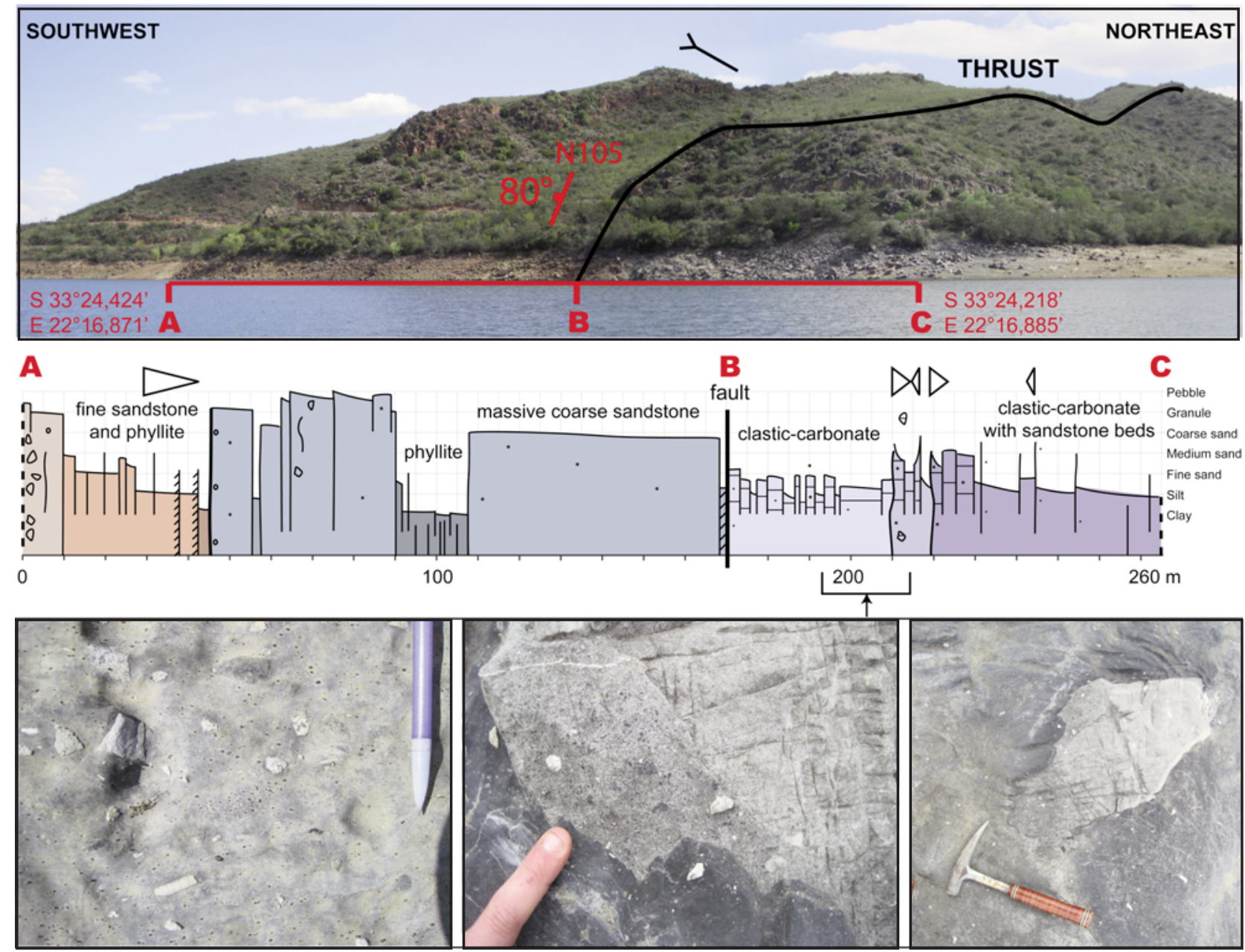

Figure 16A. Northwest-southeast cross-section and sedimentological log along the western bank of Koos Raubenheimer Dam (Fig. 15 for location). Conglomerate, sandstone and shale of the Nooitgedacht Formation are covered by clastic-carbonate rocks and shales of the Kombuis Formation. 


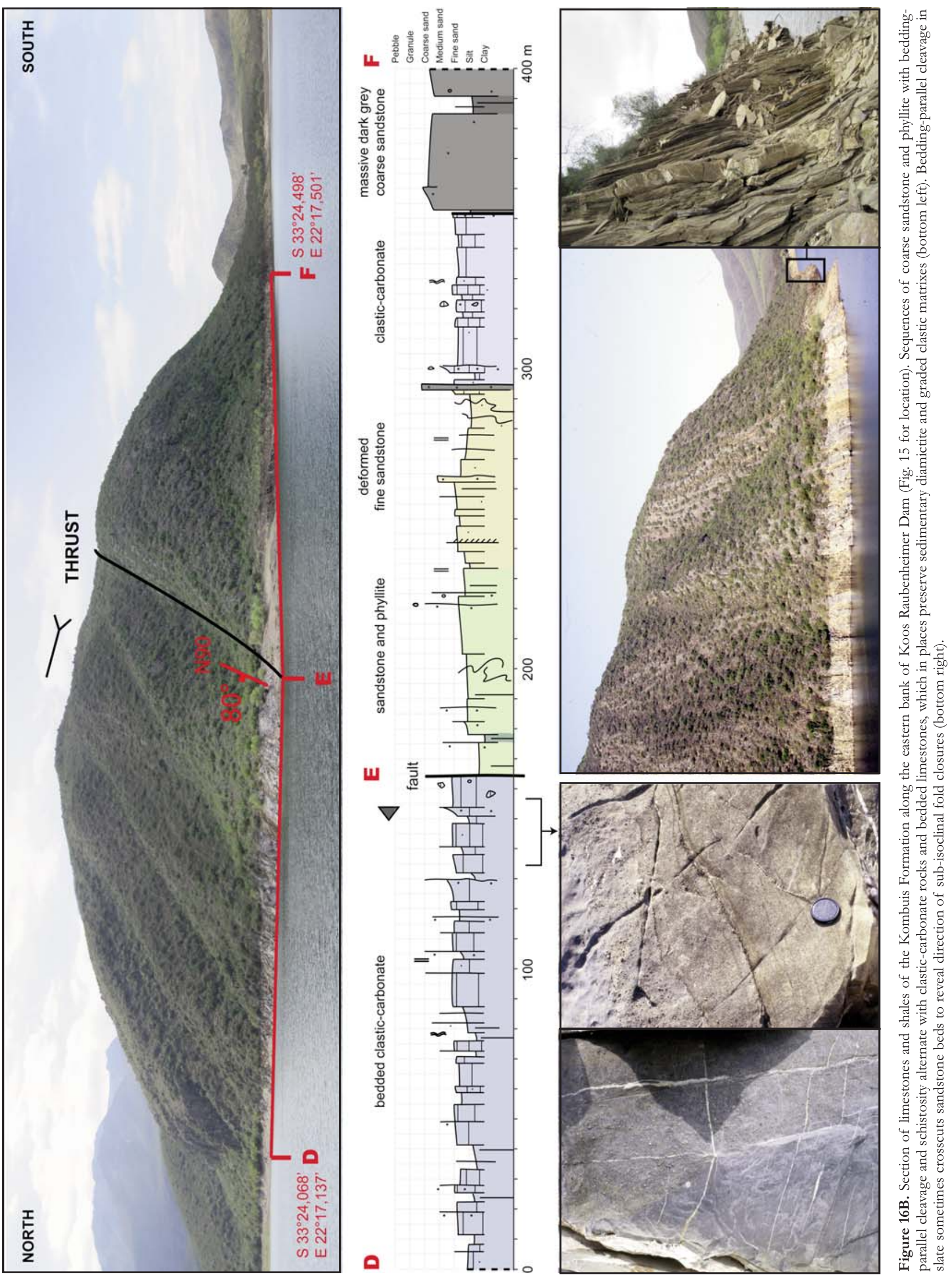




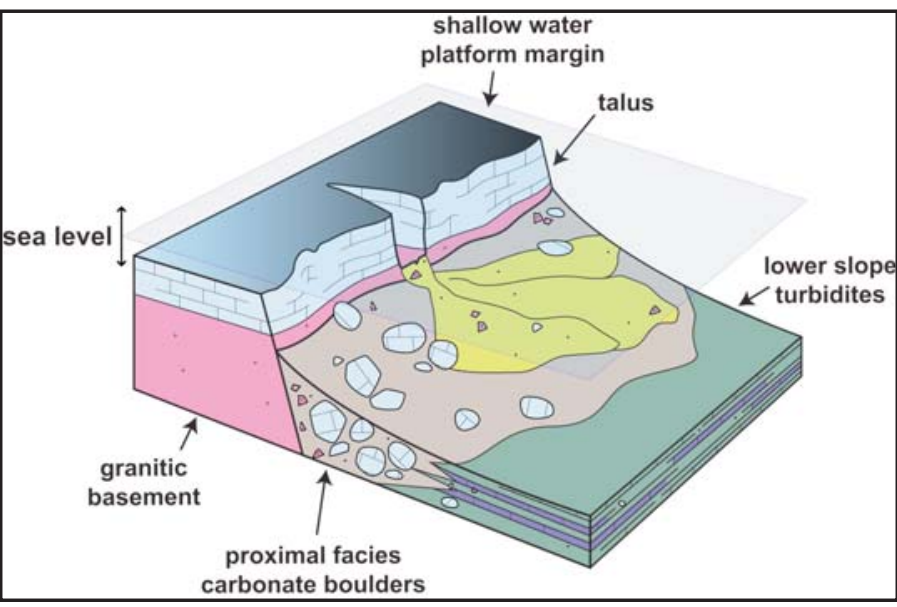

Figure 17. Schematic facies model of a submarine escarpment cut by a river section that deposited granite pegmatite and feldspathic sandstone/grit, limestone boulders and diamictite of the Kango Caves Group linked to variable sea-level changes. These carbonate sequences resemble the Lower Paleozoic marine sequences in Newfoundland, deposited across the Grenvillian basement of the Long Range Peninsula and from there eastward as far as Fleur de Lys (e.g. Figures 32-34 in James and Stevens 1986).

cate shallow marine deposition (Fig. 26b). These are underlain over ca. $2 \mathrm{~km}$ by similar, but less well-exposed subvertical sandstones and shales, cut by numerous internal shear zones and subvertical thrusts with fragmented phyllites (e.g. Fig. 26e).

The abundant bidirectional cross-bedding and flaser beds with laminated mud in the quartzite indicate rapidly changing low- and high-energy currents in an intertidal paleo-environment, such as for example sand flats in estuaries. Notably, no fossils or bioturbations have been observed anywhere in this section.

\section{Section 10. Conglomerates and Sandstones Along Schoemanspoort}

This north-south section ( $>500 \mathrm{~m}$ across), previously called
Reitkloof (Map 1), is best exposed along the main road to Oudtshoorn flanking the Grobbelaars River near Ou Tol (Old Toll House). Southward from the Toll House entrance, the section comprises well-cleaved cross-bedded arkoses and blue quartzitic sandstones with pebbles and cobbles of the Vaartwell Formation (Fig. 27). The clasts are mainly of sandstone (intraclasts) and well-rounded granite pebbles between 5 and $30 \mathrm{~cm}$ in diameter. The shale/sandstone pebbles and cobbles are mostly flattened along the cleavage, while the granite boulders generally preserve their original shapes. The subhorizontal bedding shows open folds cut by a strong east-west striking subvertical cleavage that makes the identification of bedding planes challenging in many places. In coarse-grained sandstone, younging directions from cross-stratifications are to the north.

The section is intruded by several mafic dykes, now amphibolite, with vertical schistosity, commonly with deformed quartz veins (Fig. 5a), and similar to those dated at ca. $512 \mathrm{Ma}$ in the eastern region of the Kango Complex (Haas 1998; Fig. $2 b)$.

This quartzitic sequence is equivalent to the Kansa Group conglomerate that unconformably overlies the Groenfontein Formation of the Goegamma Group, and it is here interpreted as a molasse deposit (Fig. 3). The basal contact is well exposed in the mountain section about $200 \mathrm{~m}$ higher (Barnett et al. 1997) where U-Pb detrital zircon dates reveal a Cambrian age for the conglomerate $(<518 \mathrm{Ma})$, consistent with another detrital zircon date of ca. $485 \mathrm{Ma}$ obtained from the Uitvlugt Formation (Naidoo et al. 2013). The age of the granite boulders is consistent with the age of the Saldinian (including Table Mountain) granite bodies (e.g. Scheepers and Armstrong 2002; Kirsters 2016; Miller et al. 2016).

\section{Section 11. Subvertical Unconformity Between the Kango and TMG Rocks}

TMG quartzite is coarse to fine-grained with quartz pebble

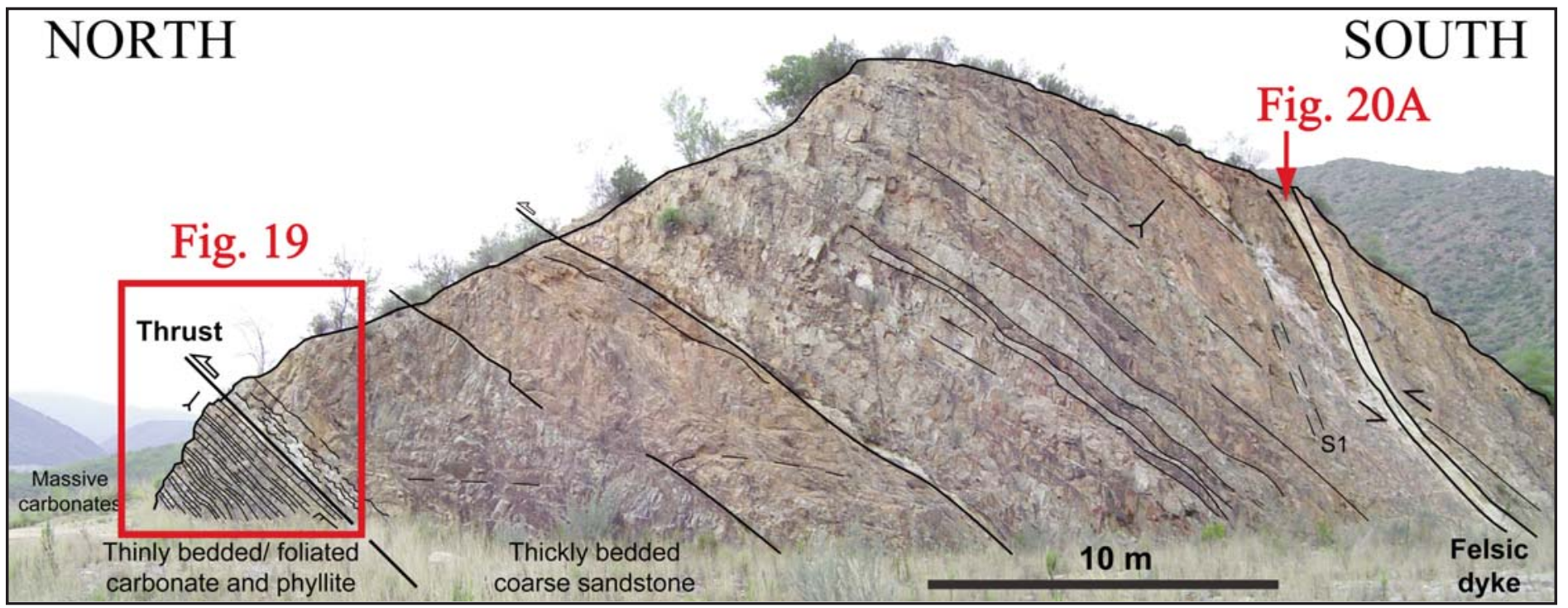

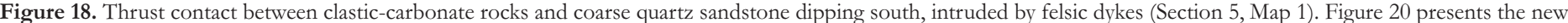
geochronology. 

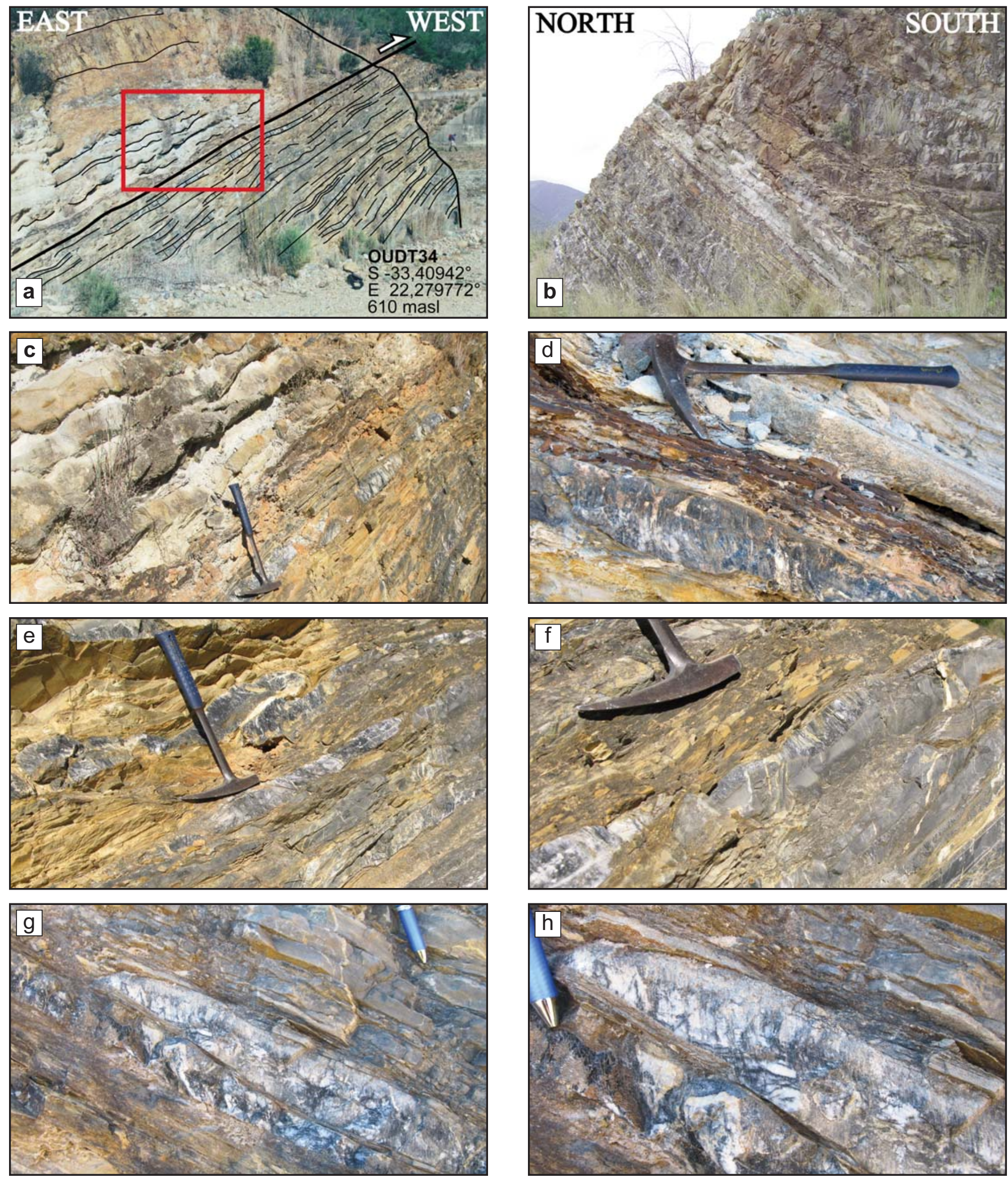

Figure 19. Along the thrust fault, thin limestone beds preserve extension veins that are duplicated - this is a complex thrust zone with episodic extensional carbonate veins (Fig. 18 for location) 

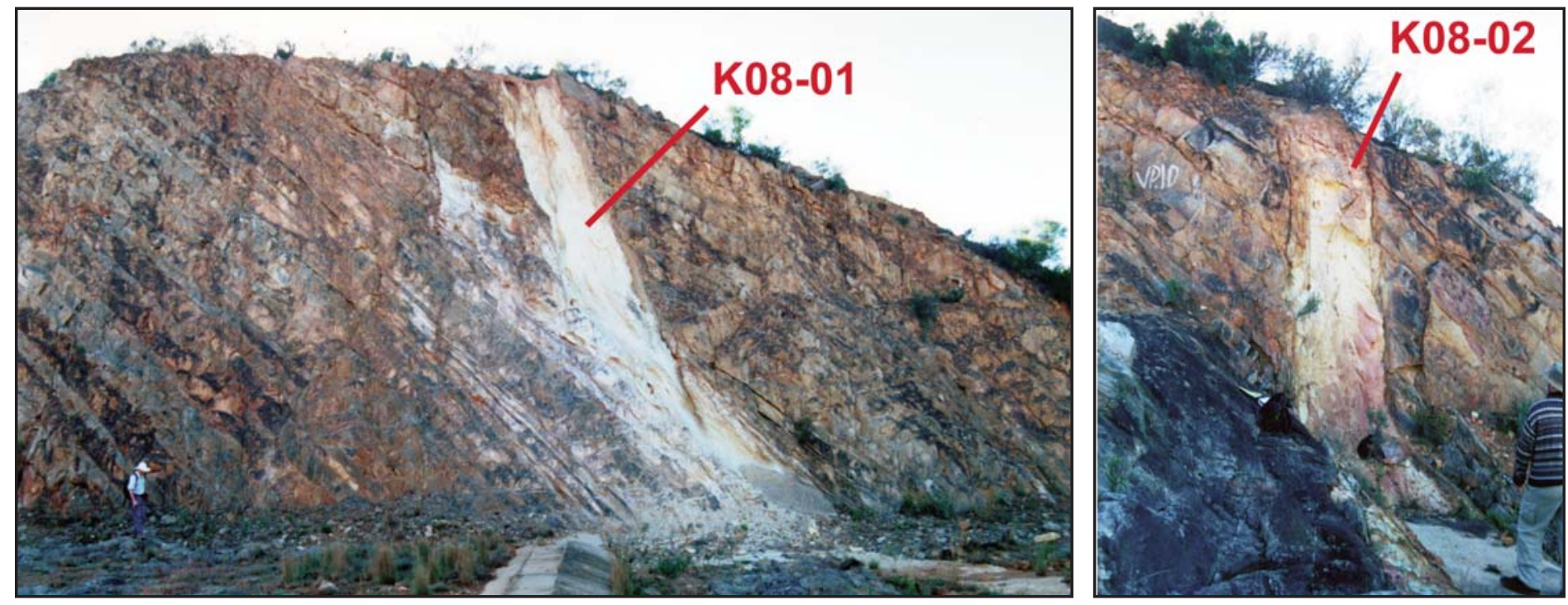

Figure 20A. South-dipping quartz sandstone (grey-red) of the Nooitgedacht Formation intruded by two steep dipping felsic dykes (white to pale brown) along the cut-off wall of the Koos Raubenheimer Dam (Fig. 18 for location).
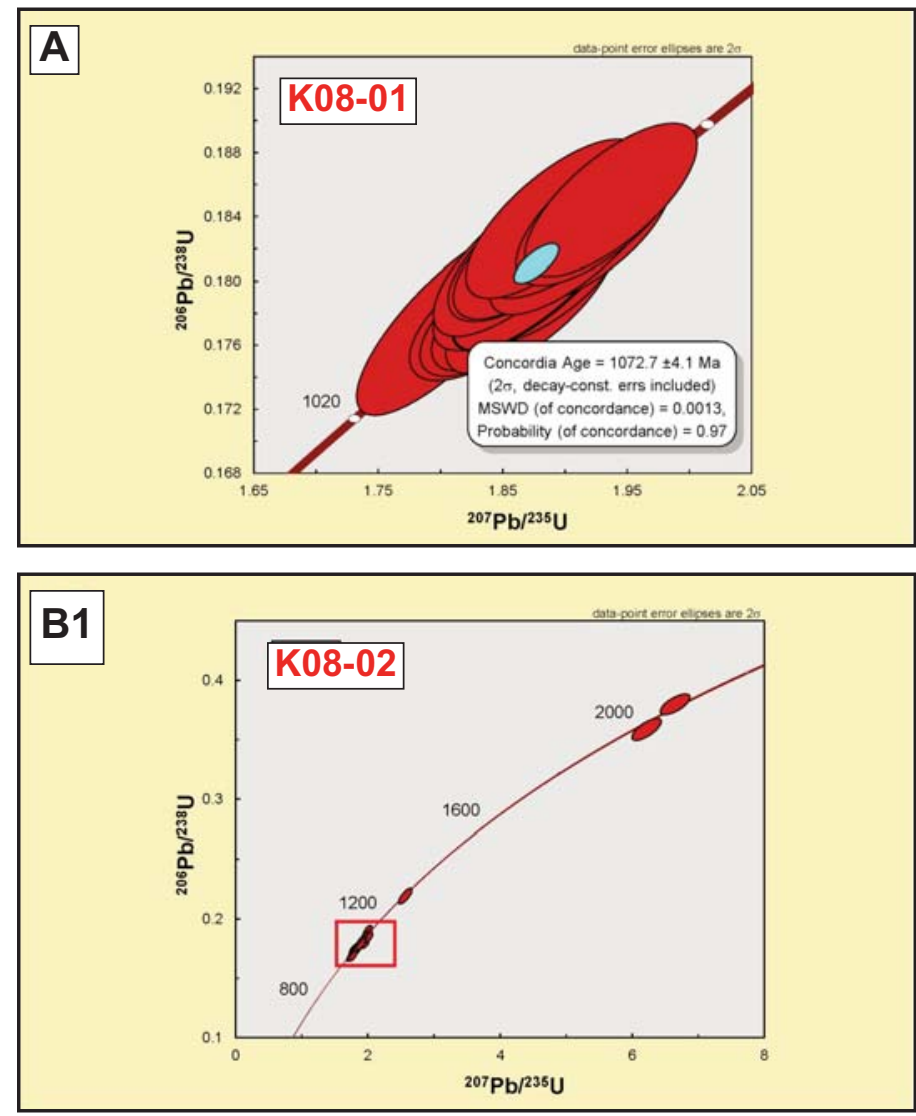

conglomerates and dips from subhorizontal to steeply north (overturned) above the Kango sequences. Deformed unconformities are well preserved in local exposures (Map 2). In most sections, the TMG directly overlies schistose greywackes and shales of the Groenfontein Formation. However, in a small folded section of the studied area (Fig. 28a), Groenfontein greywacke is unconformably overlain by schistose con-

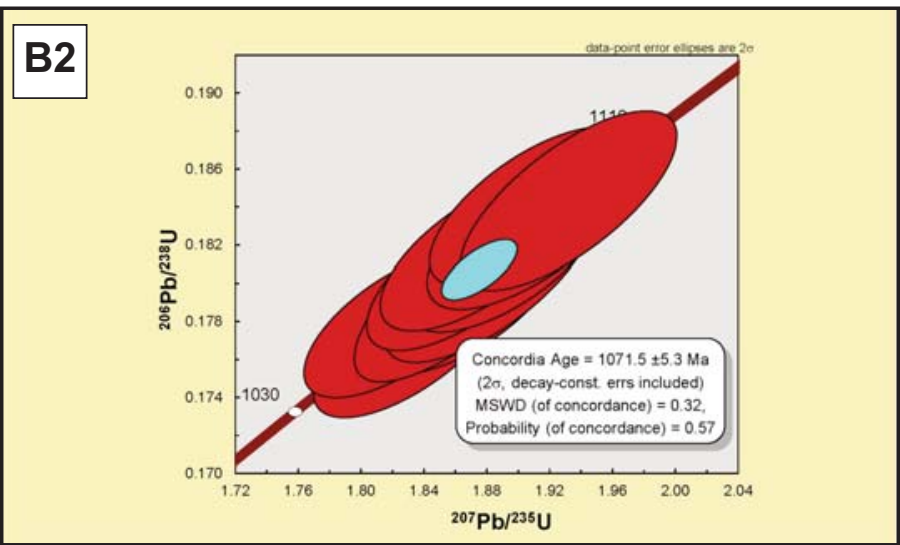

Figure 20B. U-Pb dates of igneous zircon grains from the two felsic dykes (K0801 and 02 ; Fig. 20A) at ca. $1072 \mathrm{Ma}$ are interpreted to represents the age of intrusion, and with ca. $2000 \mathrm{Ma}$ inherited zircons (B1). Data are provided in Appendix ( 2 s, decay-constant errors included).

glomerates, sandstones and shales of the Schoongezigt (Gezindskraal) Formation, which in turn are unconformably overlain by quartzites and conglomerates of the TMG. This feature outcrops best in an open to close fold exposure, confirming that the main deformation across the Kango Complex is of post-TMG age, and thus likely linked to the Cape Fold Belt orogeny at ca. $252 \mathrm{Ma}$. 

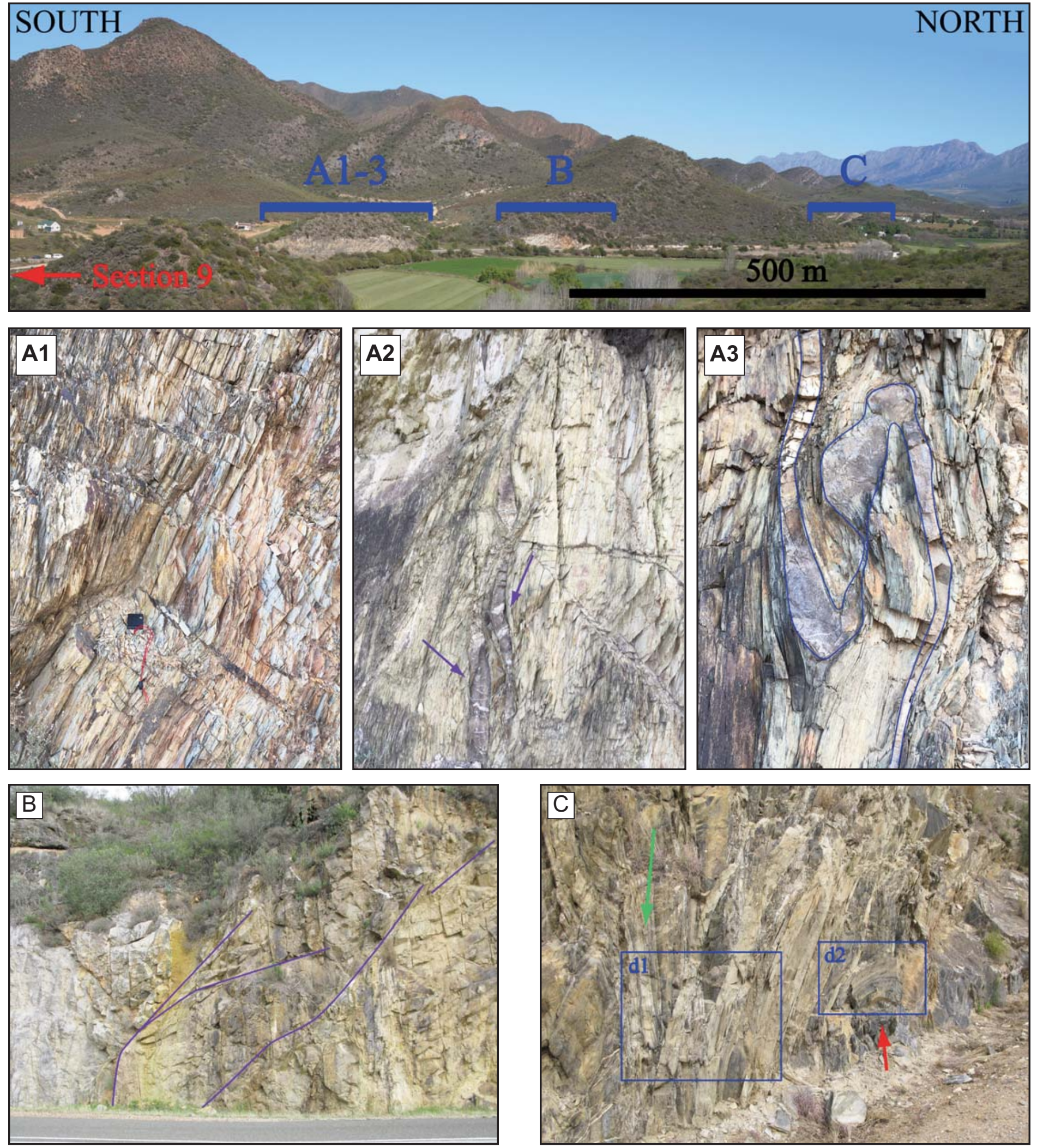

Figure 21. Section 6 of phyllites-psammites and foliated carbonate rocks of the Kango Caves Group; for location see Map 1. (A1) Phyllitic schist (pale yellow) with thin dismembered marble lenses, (A2) with limestone marble boudins and with isoclinally folded limestone lenses (blue-grey with white carbonate veins), and (A3) typical thin slate unit (dark grey with white quartz veins) duplicated within a thrust zone separating massive sandstone beds (pale grey). (B) Thrust between carbonate section (left) and phyllites-sandstones with thin grey carbonate limestone units (right and small thrusts within this unit). (C) Open fold of limestone (dark grey, red arrow) and subvertical limb of sandstone (green arrow), cut by steep dipping felsic dykes (d1 and d2 = highlighted in Fig. 22A). 

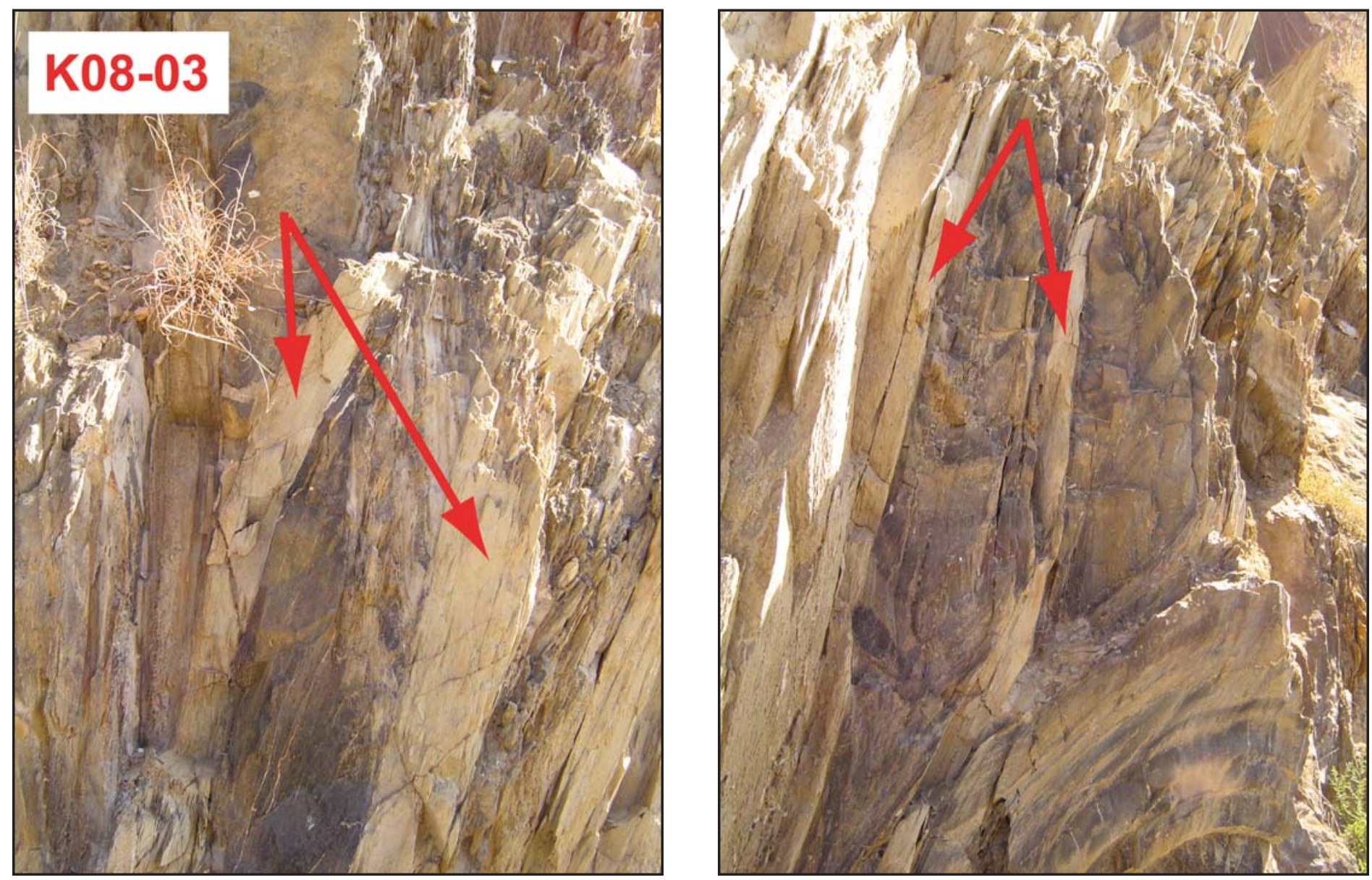

Figure 22A. Thin subvertical felsic dykes (red arrows) with parallel cleavage that is also axial planar to intruded subhorizontal open folded limestone (dark grey) and subvertical psammite beds (pale yellow), exposed $30 \mathrm{~m}$ below a major subvertical thrust zone (Fig. 4C).
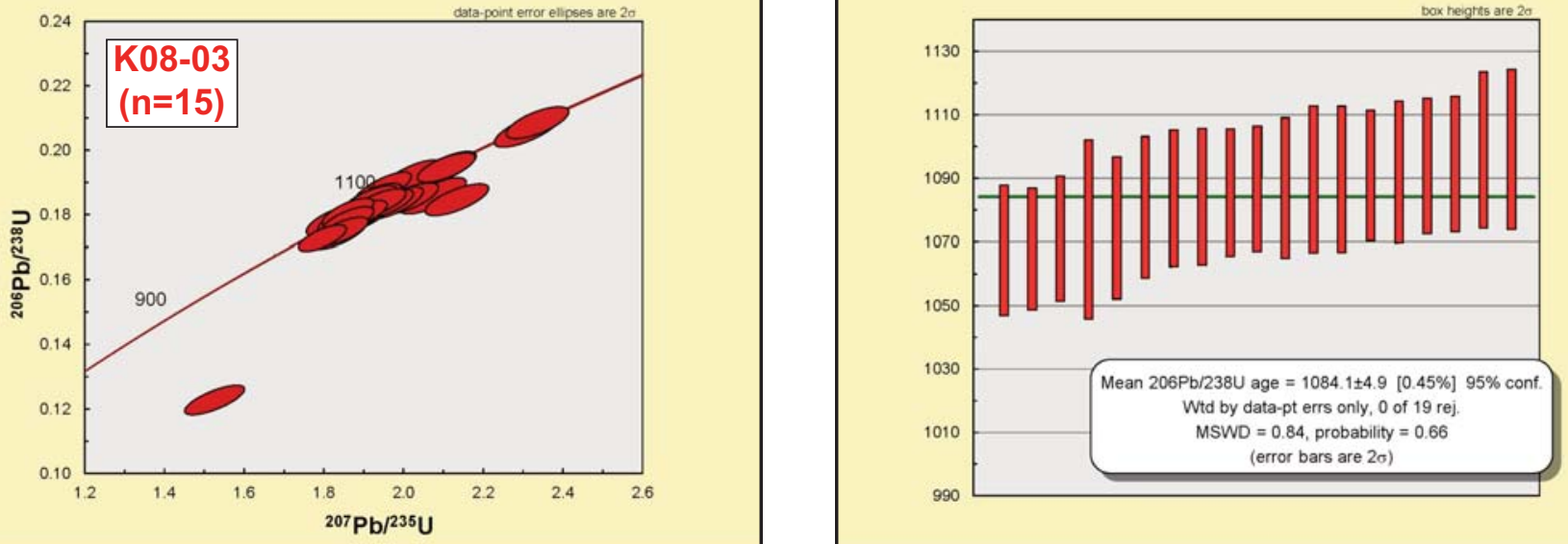

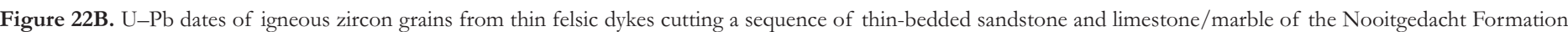

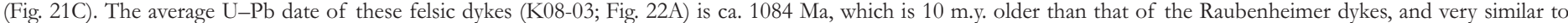

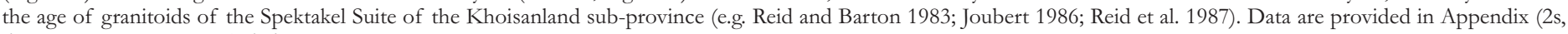
decay constant errors included). 


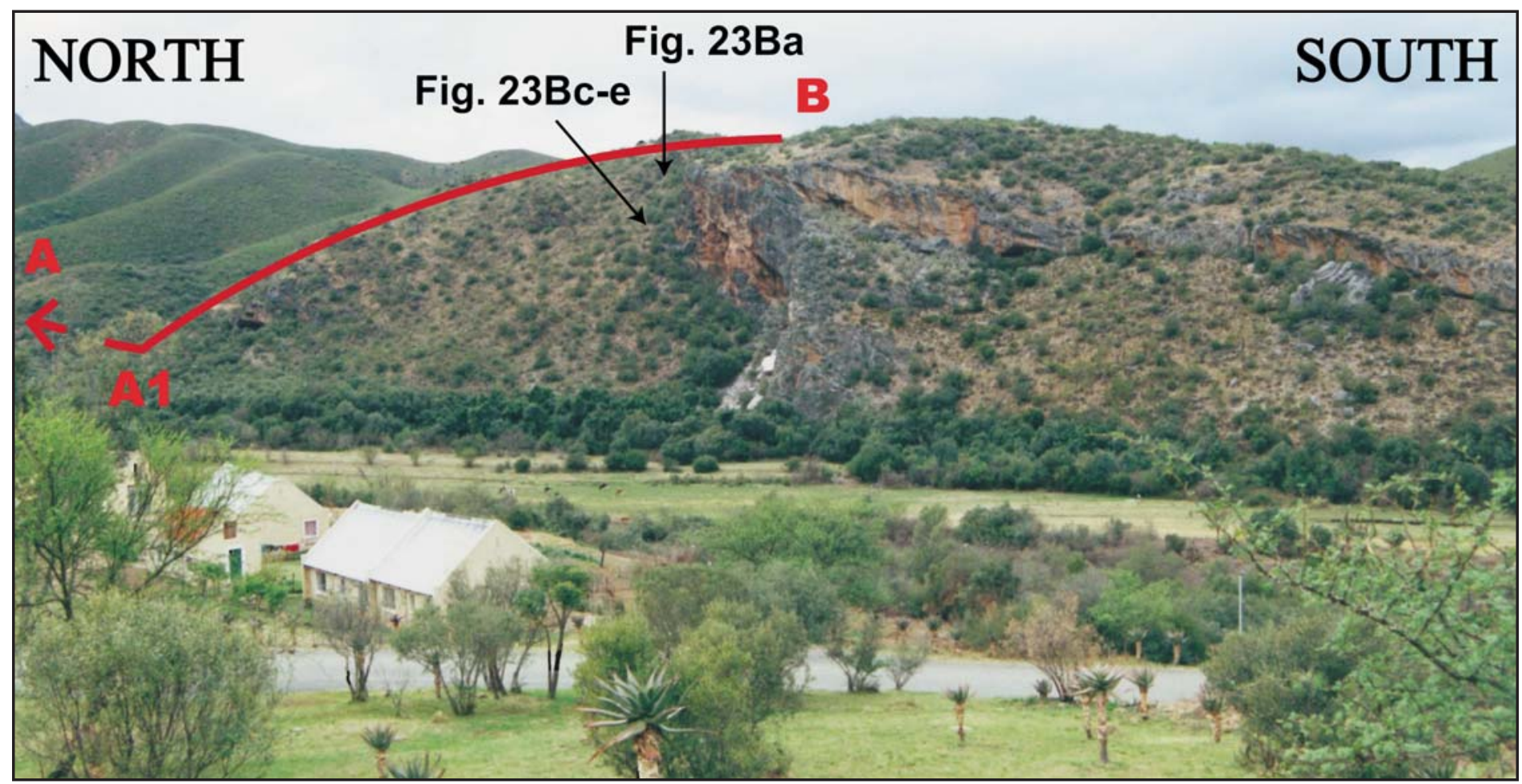

Figure 23A. Clastic limestone (orange weathering) about $100 \mathrm{~m}$ thick, exposed at De Hoek Cave near the Resort (Section 7, Map 1).

Frequently, highly schistose zones within the TMG, parallel to its bedding, are well exposed close to the contact with the Kango rocks (Fig. 28c-h), and shallow north-facing and folded thrusts are well exposed within the TMG well above the contact (Fig. 4E, and see below). Steeply dipping, axial planar cleavage is well developed in open folded shale of the Goegamma Group, and reveals a near parallel bedding between the two groups (Fig. 28b).

\section{Section 12. Subhorizontal Unconformity Between the Kango and TMG Rocks}

Stretching some $2 \mathrm{~km}$ south from the subvertical dipping contact between the Kango and TMG rocks along the Swartberg Range, two sections of subhorizontal bedded quartzite of the TMG outcrop unconformably across the Groenfontein shales and sandstones (Fig. 29). The Groenfontein Formation has a subvertical cleavage or schistosity linked to open well-spaced subvertical fractures in the overlying quartzite. The bedding orientations of shales across these outcrops are part of open folded subhorizontal sequences.

This subhorizontal section of TMG covering the Kango Complex is only very locally preserved, but the TMG outcrops across the entire study area in the west (Fig. 30). Here, the shallow dipping contact across the southern margin is overlain by a thrust duplex of TMG quartzite, with a total early subhorizontal shortening of about $75 \%$. This is similar to thrust zones across the subvertical, but poorly outcropping TMG quartzite flanking the southern margin of the eastern Kango Complex (Map 2).

\section{GEOMORPHOLOGY}

\section{Cretaceous to Present Erosion Rates}

Rounded boulders of TMG quartzite cover remnants of the old flat regional topography preserved at ca. 1000-700 m asl, above the Kango sequences (Fig. 31). The onset of subsequent deeper river erosion implies that climate variation created an opportunity to open caves from the top of these flat surfaces along the subvertical contacts of limestone-marble with pelitic schist and sandstone of the Nooitgedacht Formation, linked to small rivers that eroded down to about $600 \mathrm{~m}$ asl (Decker et al. 2013). Similar caves occur along the contact of the Kango Caves Group conglomerate with the Groenfontein pelitepsammite units (for all caves location see Map 2).

Erosion rates changed considerably from ca. 100-200 $\mathrm{m} / \mathrm{m}$.y. during the Cretaceous $(140-80 \mathrm{Ma})$, based on apatite fission track analyses (AFTA) on deep borehole samples just north of the Swartberg Mountains, to less than ca. 10-20 $\mathrm{m} / \mathrm{m} . \mathrm{y}$. in the Cenozoic around 60-30 Ma; and, less than ca. 3-6 m/m.y. over the last 5 m.y., based on measurements of three river systems in the study area (Fig. 2b). Thus, the deep valleys across the Kango rocks are not due to the slow erosion during the relatively dry recent climate (e.g. Flowers and Schoene 2010; Scharf et al. 2013; Kounov et al. 2015; Evans 2015 and references therein). The origin of the Cango Caves may therefore link to high precipitation times before $60 \mathrm{Ma}$, and the formation of stalagmites during significantly reduced precipitation periods, as confirmed by their oldest known age of about $200 \mathrm{ka}$ (de Wit et al. unpublished). 

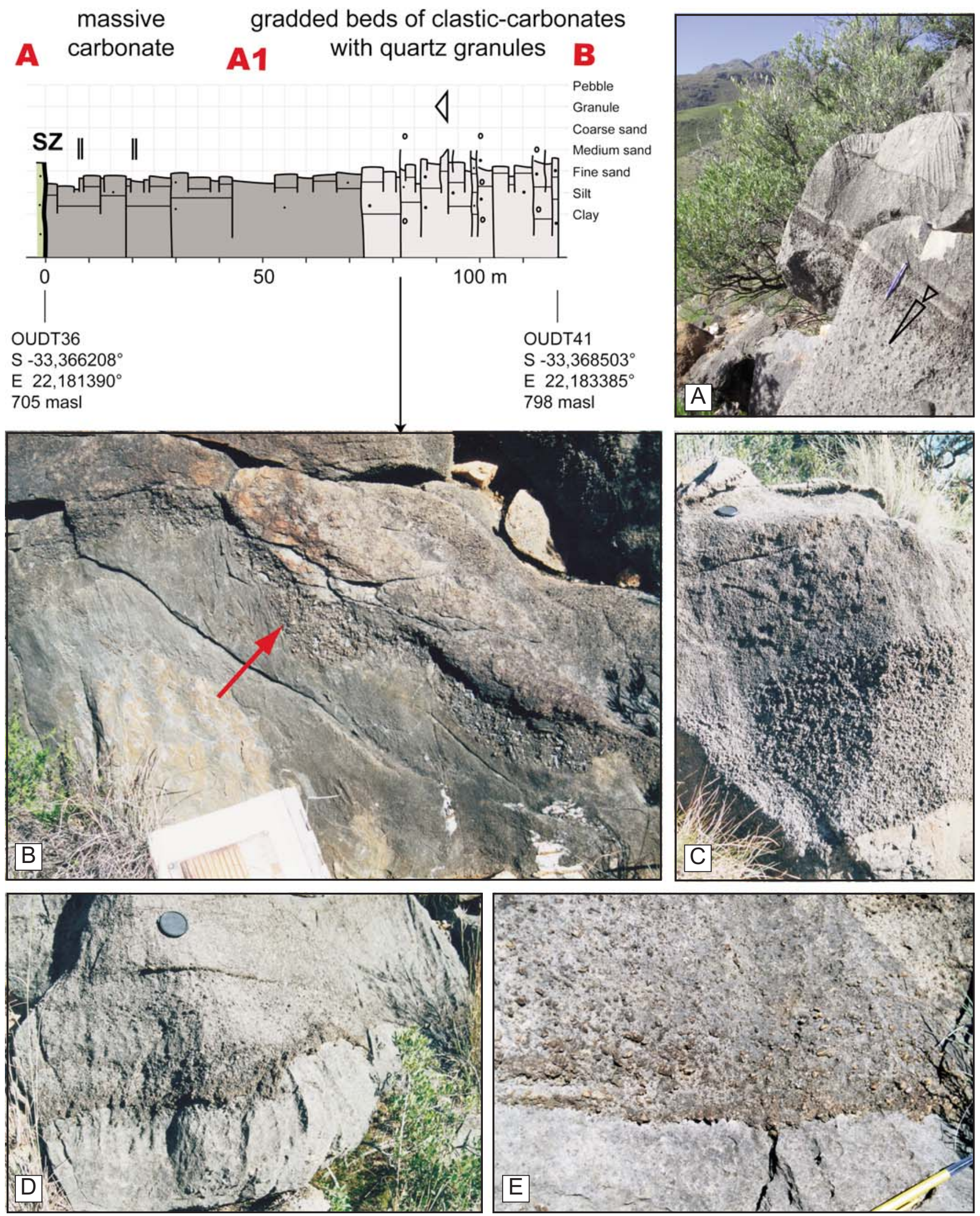

Figure 23B. The sedimentary log highlights a $120 \mathrm{~m}$ thick succession (Fig. 23A) that preserves both fining-up and coarsening-up graded beds of limestone (grey) with granule to gravel-sized quartz (brown). Erosion surfaces (red arrow pointing up) indicate younging to the south. 

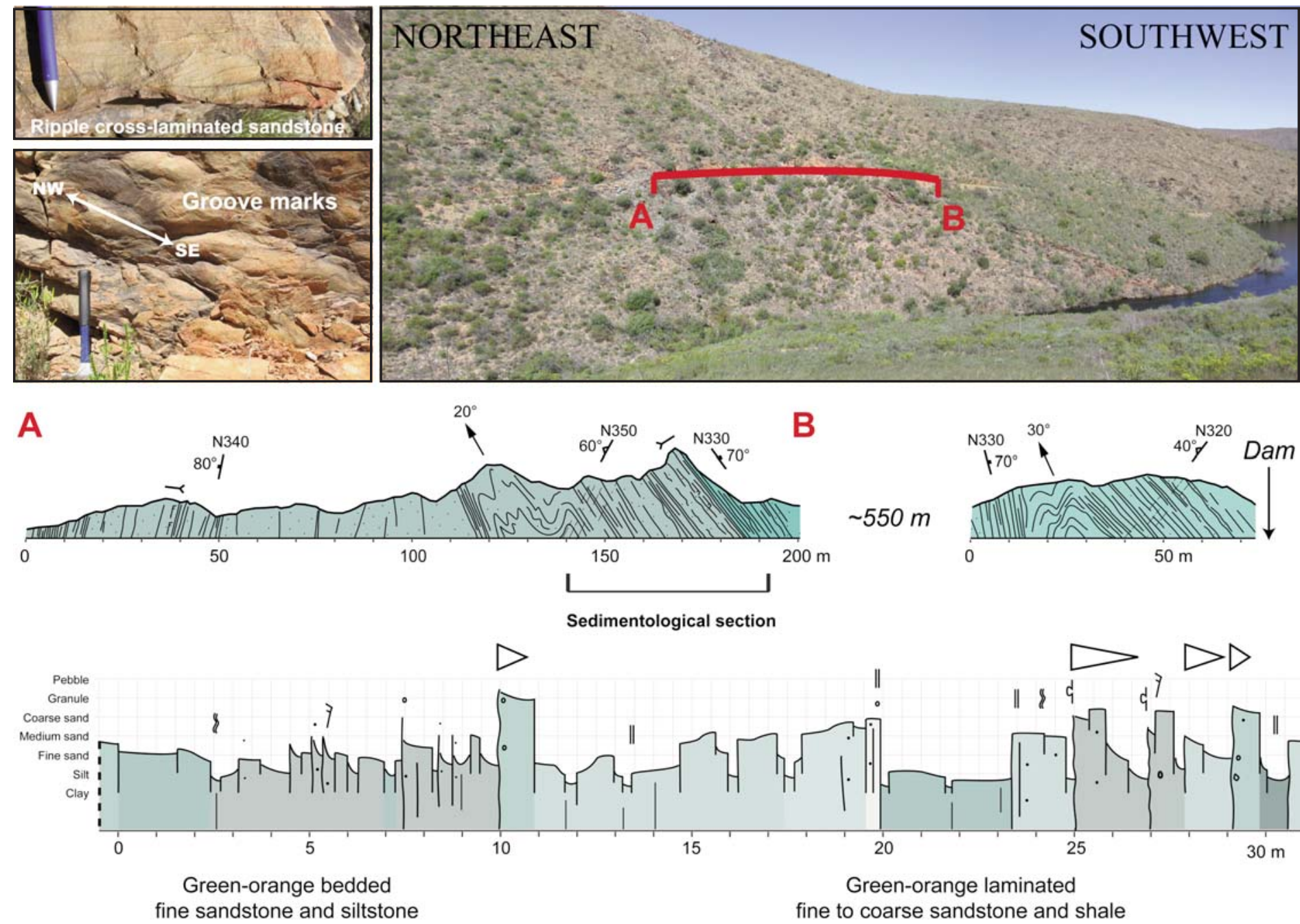

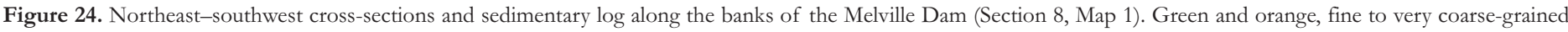
sandstone, siltstone and shale of the Groenfontein Formation are characteristic of turbidites and show north-verging folds.

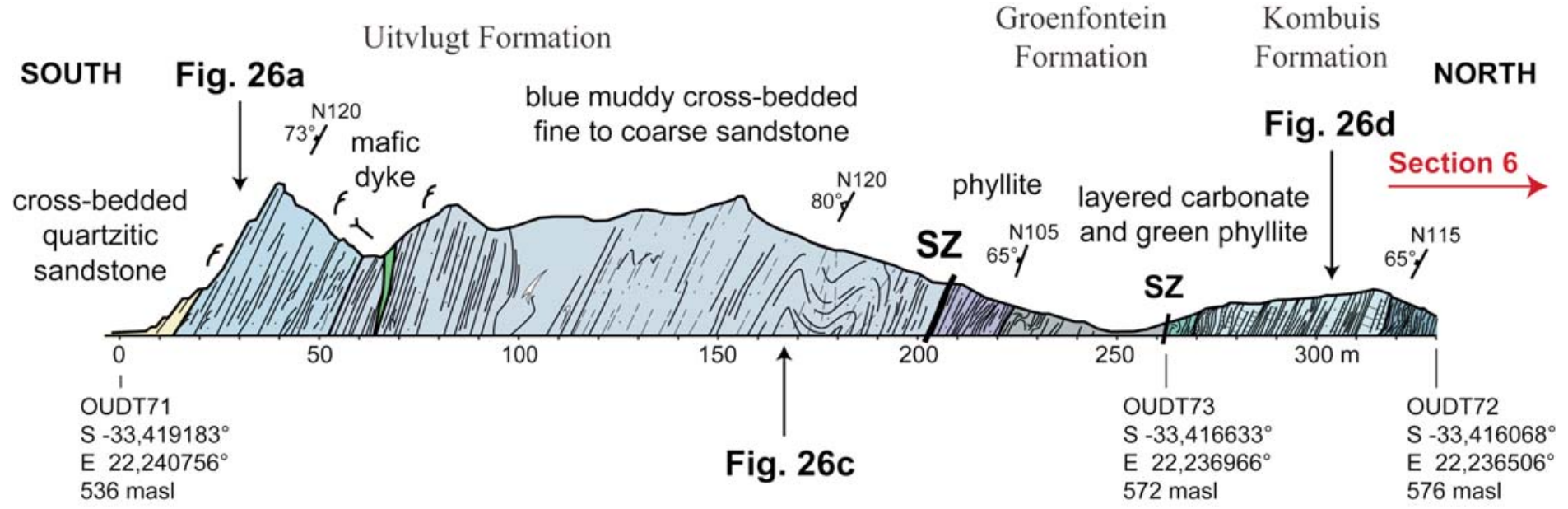

Figure 25. North-south cross-section more than $300 \mathrm{~m}$ long along the main road near Kombuis (Section 9, Map 1). 

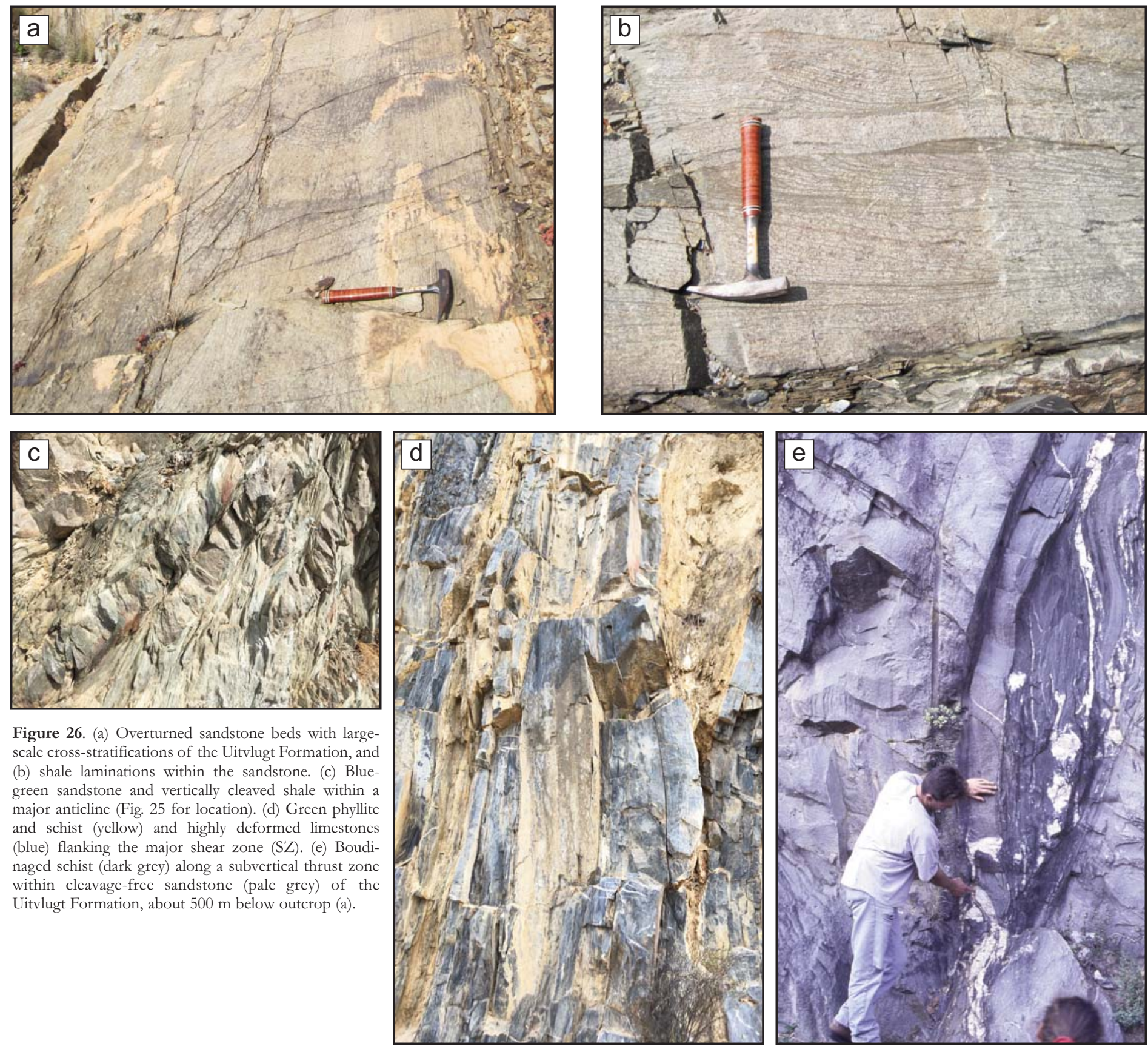

Figure 26. (a) Overturned sandstone beds with largescale cross-stratifications of the Uitvlugt Formation, and (b) shale laminations within the sandstone. (c) Bluegreen sandstone and vertically cleaved shale within a major anticline (Fig. 25 for location). (d) Green phyllite and schist (yellow) and highly deformed limestones (blue) flanking the major shear zone (SZ). (e) Boudinaged schist (dark grey) along a subvertical thrust zone within cleavage-free sandstone (pale grey) of the Uitvlugt Formation, about $500 \mathrm{~m}$ below outcrop (a).

\section{Caves Flanking the Contact of Limestones with Greywackes}

Karst topography and linked caves near the contact between the carbonate rocks of the Kombuis Formation and the pelite-psammite units of the Groenfontein Formation have been described by many field geologists; and while the paleodeposition system along this contact has been debated, all described the contact as an unconformity (e.g. Le Roux 1977, 1983, 1997; Le Roux and Gresse 1983; Gaucher and Germs 2006; Praekelt et al. 2008; Nel et al. 2018).

The best preserved evidence of such an unconformity is within the major fold closure exposed in the centre of the studied area where the unconformity surface dips steeply (Map
2). By contrast, the contact between these two formations along the fold limbs is cleaved and highly deformed along vertical shear zones, and most of the direct relationship between schistose shales and carbonate rocks is poorly visible and eroded, with the carbonate rocks being slightly more elevated at present (Fig. 32a).

The tectonic contact is commonly flanked by a section of carbonate conglomerate near the top of the Kombuis Formation along which at least five sinkhole localities are well-preserved (Fig. 6). Only one of these sinkholes is open deep below surface, and often explored by cavers who assume it to be linked to the Cango Caves via subsurface groundwater systems. All others are filled with sand and, at least at surface, with 


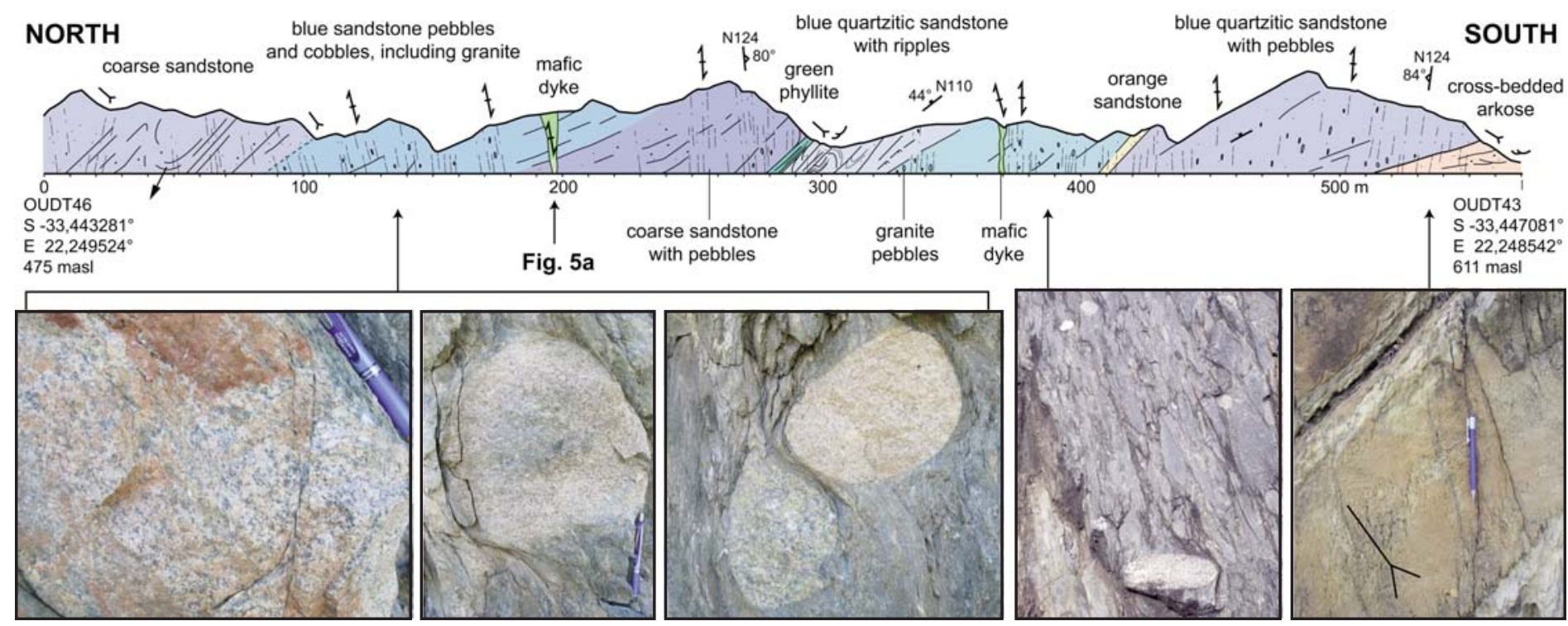

Figure 27. North-south cross-section of variably deformed/foliated conglomerates and psammites (sandstone) near Schoemanspoort (Section 10, Map 1). Well-rounded granite pebbles and cobbles remain resistant against the subvertical phyllite of the greenish blue pelitic psammite (left), compared to highly elongate sediment boulders (second right). In less deformed sections, graded sandstone beds with cross-stratification (right) confirm upward grading and define local open folds axis. These sequences are older than the $512 \mathrm{Ma}$ basic dykes, and the granite blocks are likely linked to the Cape/Saldanian batholiths exposed along the western and southern coasts (Fig. 2a and cross-sections below).

quartzite boulders and pebbles, fragments of carbonate rock, and in places covered by iron precipitate (Fig. 32b-d).

We interpret these karst structures as relatively recent sinkholes likely filled during the early erosion of TMG quartzite, perhaps linked to glaciation-deglaciation of the Swartberg Mountains. By contrast, Praekelt et al. (2008) interpreted these sinkholes as paleokarst structures and paleovalleys filled with Neoproterozoic glacial deposits along the unconformity on top of the Kombuis carbonates, and fossilized by the Groenfontein turbidites. This interpretation is based on purported Late Ediacaran architarchs across the surface sinkholes mentioned above, and the fact that this paleokarst topography reveals development of subaerial unconformities (Gaucher and Germs 2006; Praekelt et al. 2008; Naidoo et al. 2013; Nel et al. 2018). While the biological affinities of architarchs cannot be determined with certainty, they may have been previously linked to stromatolites along the contacts between shale and carbonate. It is also possible that these are recently eroded stalagmites and carbonate precipitates, which are at present abundantly preserved in and around the Cango Caves.

Until more detailed analyses of these artefacts are provided, they remain in the realm of pseudo-fossils, especially as the (now deformed) unconformity contact between these sequences predates the deposition of the Goegamma Group (> 670 Ma; Fig. 33). Similarly, the existence of Neoproterozoic microfossils at the Cango Caves is unlikely, since the limestone is highly deformed (Fig. 7) and intruded by Mesoproterozoic felsic dykes (Fig. 22).

\section{SYNTHESIS OF KANGO STRATIGRAPHY AND LANDSCAPES}

Below we summarize the stratigraphy and landscape evolution across our study area (Fig. 33), and use these data to recon- struct simple models for the deposition and erosion history (Figs. 34 and 35).

The complete section across the central Kango Complex, close to the Cango Caves (Map 1), has a stratigraphic thickness of some $10 \mathrm{~km}$ that covers a time span of $700-800$ m.y. The section contains at least $50 \%$ phyllite, suggesting a thickness of at least $20-30 \mathrm{~km}$ before tectonic compression. However, folding into a near isoclinal system across this section halves the stratigraphic thickness to some $10-15 \mathrm{~km}$, which appears reasonable if somewhat simplified without evaluating changes linked to the many thrust systems that have affected the area.

Many dated detrital zircons between 2.0 and 0.9 Ga recorded in the Kango sequences are likely derived from Mesoproterozoic basement that directly underlies this series (Fig. 2a). The (non-exposed) basement in the southern extremity of Africa is not Pan-African in age, as widely assumed, but most likely Namaquan (Grenvillian in age), ranging between 1.3 and 1.0 Ga (Hartnady 1969; Eglington and Armstrong 2003; McCourt et al. 2006; Lindeque et al. 2007; Stankiewicz et al. 2007; Linol and de Wit 2016).

Recent seismic and magnetic sections across the CapeKaroo topography, including the present studied region, reveal relatively flat Namaquan basement between 5 and $10 \mathrm{~km}$ below surface. It is likely therefore that sediment was deposited in local basins after rapid erosion of the Namaquan sequences across western South Africa that were metamorphosed at relatively low-pressure granulite facies, followed by intrusion of late felsic magmatism at ca. 1.0 Ga (e.g. Waters 1986, 1990; Cornell et al. 2006; Cornell and Pettersson 2007).

The closest dates to compare with the age of the felsic dykes dated in this study are those from the Mesoproterozoic Kliphoek and Garies granites, which have dates of ca. $1078 \pm$ $5 \mathrm{Ma}$ (de Beer and Macey 2016a, b). These ages are within 

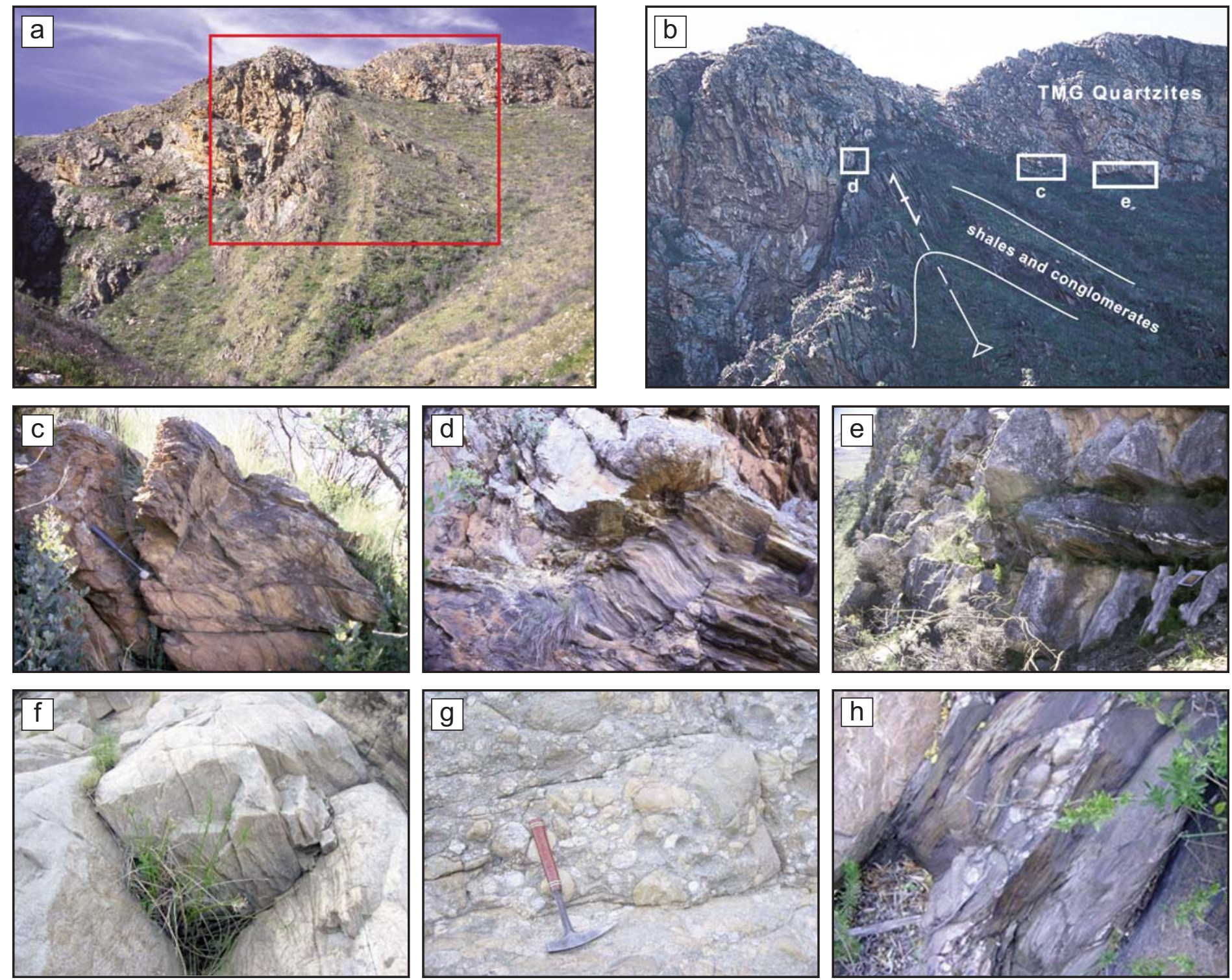

Figure 28. (a) Folded unconformity between the Goegamma Group and TMG quartzite (Section 11, Map 1), showing (b) the subvertical cleavage where slates of the Schoongezigt Formation are axial planar to a relatively shallow north-plunging open fold. Across this contact, TMG quartzite is cut by widely spaced axial planar fractures. (c) Steeply dipping schistosity across subhorizontal bedding of Schoongezigt pelite and psammite, (d) directly below the unconformity and (e) separated by a tectonic shear zone from the subhorizontal TMG. (f) Typical TMG quartzite, (g) conglomerate, sometimes (h) in bedding parallel shear zones, along the Kango-TMG contact at the northern margin of the Kango Complex.

error of the dated felsic dykes intruding the lower sections of the Kango Caves Group (ca. $1084 \pm 5$ Ma; Fig. 22). They also link closely to detrital zircon dates in the Kansa Group (ca. 1030-1080 Ma; Barnett et al. 1996; Naidoo et al. 2013). By contrast, intrusion of the ca. $512 \mathrm{Ma}$ old mafic dykes were likely linked to uplift following local Pan-African deformation, often referred to as the Saldanian orogeny (e.g. Scheepers and Armstrong 2002; Gresse et al. 2009), linked along the western margin of South Africa to the East Brasilian orogens in South America (de Wit et al. 2008), and which may thus be responsible for the allochthonous and molasse deposition of the Kansa Group.

\section{Geo-rates - 'More Gaps Than Records'}

A $10-15 \mathrm{~km}$ thick stratigraphic thickness covering this 700 m.y. time period reveals an average thickness of deposition between 1 and $2 \mathrm{~m} / \mathrm{m} . \mathrm{y}$, and thus a rate of some $1-2 \mathrm{~mm} / \mathrm{ka}$, nearly 30-40 times less than the accumulation rates of limestone under the Bahamas (4-6 cm/ka; Newell 1967; Ager 1992) and 10 times less than modern sediment preservation rates on the floor of the Indian Ocean (Fig. 35). Given the thickness of many carbonate turbidites and diamictite units in the studied area, this seems extraordinarily low. While many identified unconformities and disconformities across bedding planes represent significant time gaps, more time must therefore be missing across the Kango stratigraphy due to nondeposition and erosion. 

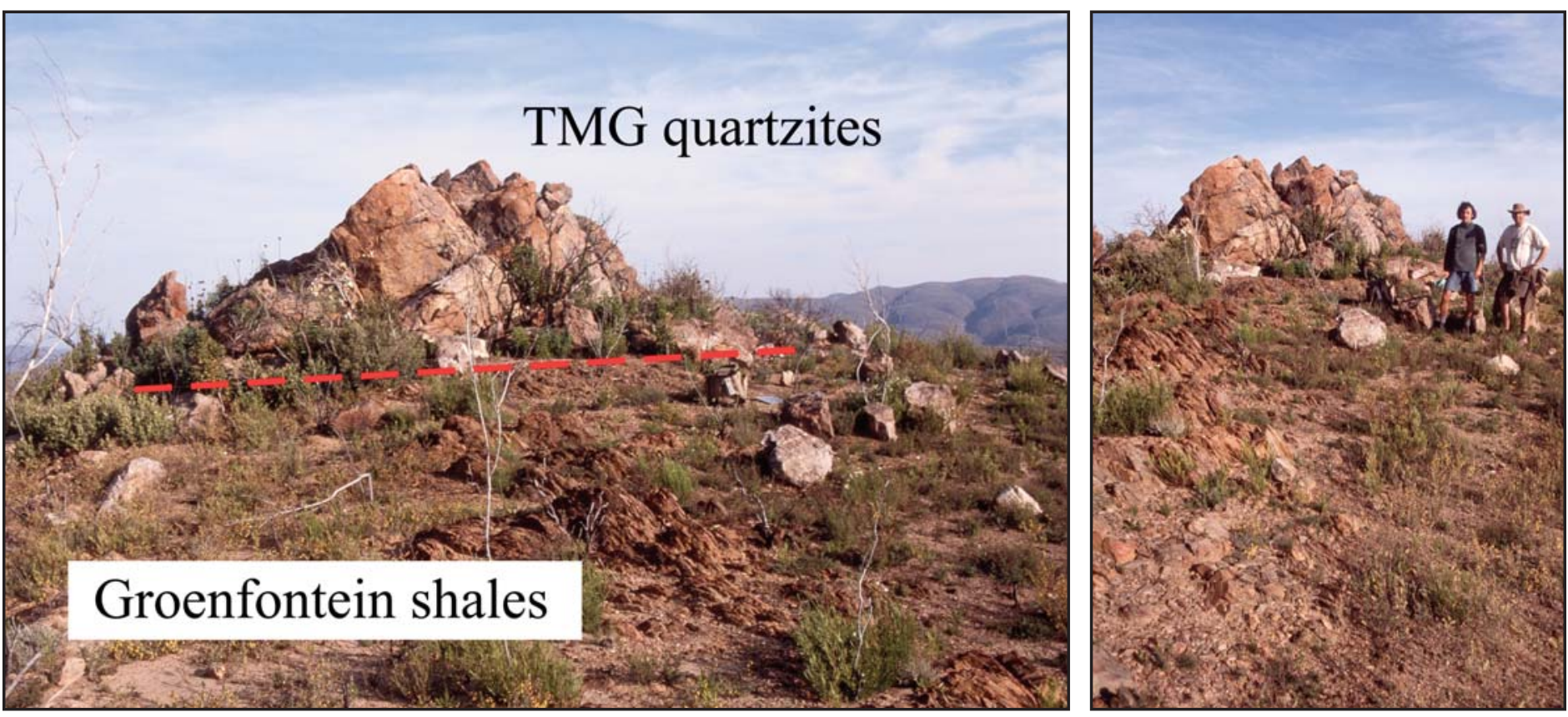

Figure 29. Subhorizontal contact between the Groenfontein Formation turbidites and TMG quartzite, cut by subvertical cleavage and joints, respectively (Section 12, Map 1); for scale students Jacek Stankiewicz (left) and John Decker (right) who first discovered these outcrops in 2004.

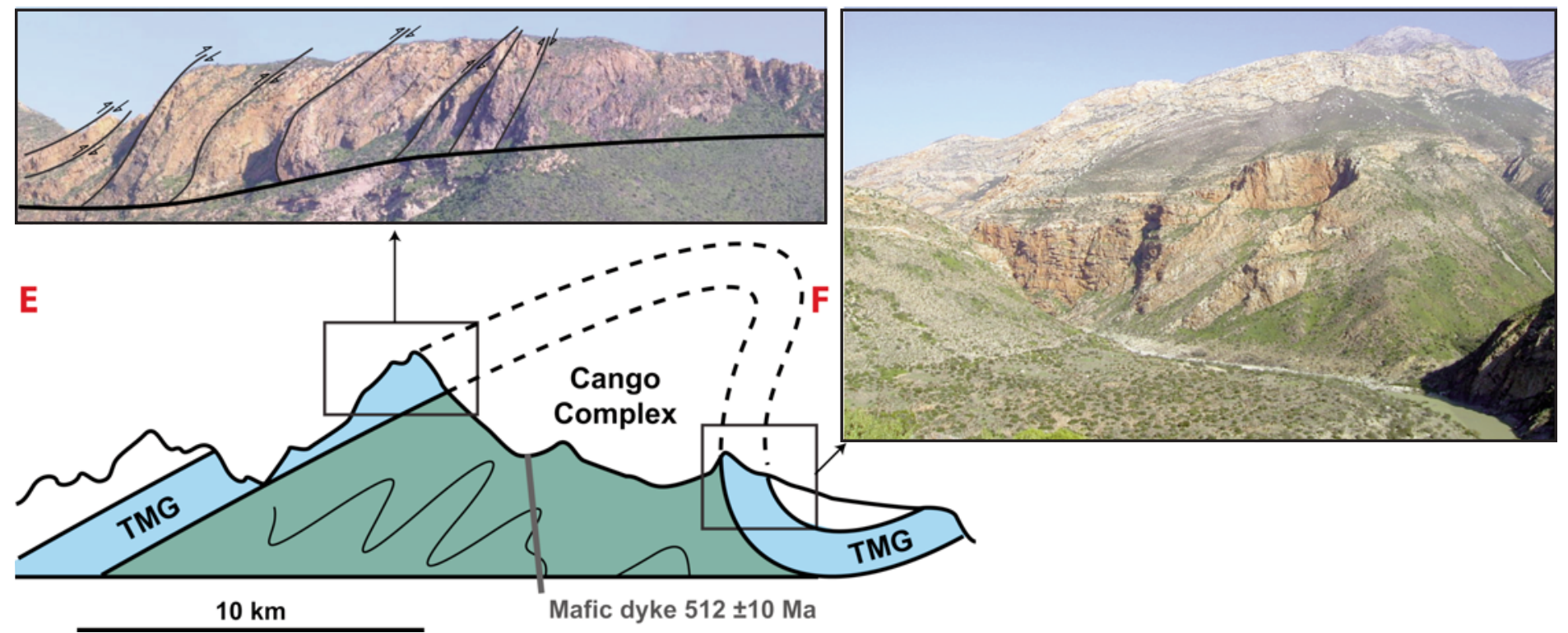

Figure 30. Schematic section across the western Cango region (Fig. 2b for location), showing a (pre-fold) accretionary thrust zone that tectonically separates TMG quartzite from Groenfontein turbidites (top left); and along an overturned section of the TMG, well-exposed along the Gamka River in the Hell (top right). Frequent conglomerate sections of the TMG preserve unconformable contacts. The dolerite dyke dated at $512 \mathrm{Ma}$ links to a series of intrusive gabbro bodies in this area of the Kango Complex (Haas, 1998)

The Kango Complex represents an inescapable example of long gaps with only occasional records of sedimentation (cf. Ager 1992). It needs much created micro-stratigraphy nit-picking, linked to new geochronology techniques, to quantify these hiatuses and how they represent regional erosion processes linked to the Namaquan and Pan-African mobile belt orogens and the Kalahari epeirogeny (Dewey et al. 2006; de Wit 2007).
Since its present stalagmites date back at least $200 \mathrm{ka}$, Ager's famous idealized diagram of the condensed sequences preserved in solution hollows of Jurassic limestone (Fig. 32; Ager 1992) also fits the Cango Caves and their linked subsurface river systems well. In this case, condensed sequences within the caves may link back more than $300 \mathrm{Ma}$ to the Carboniferous (Fig. 33). 

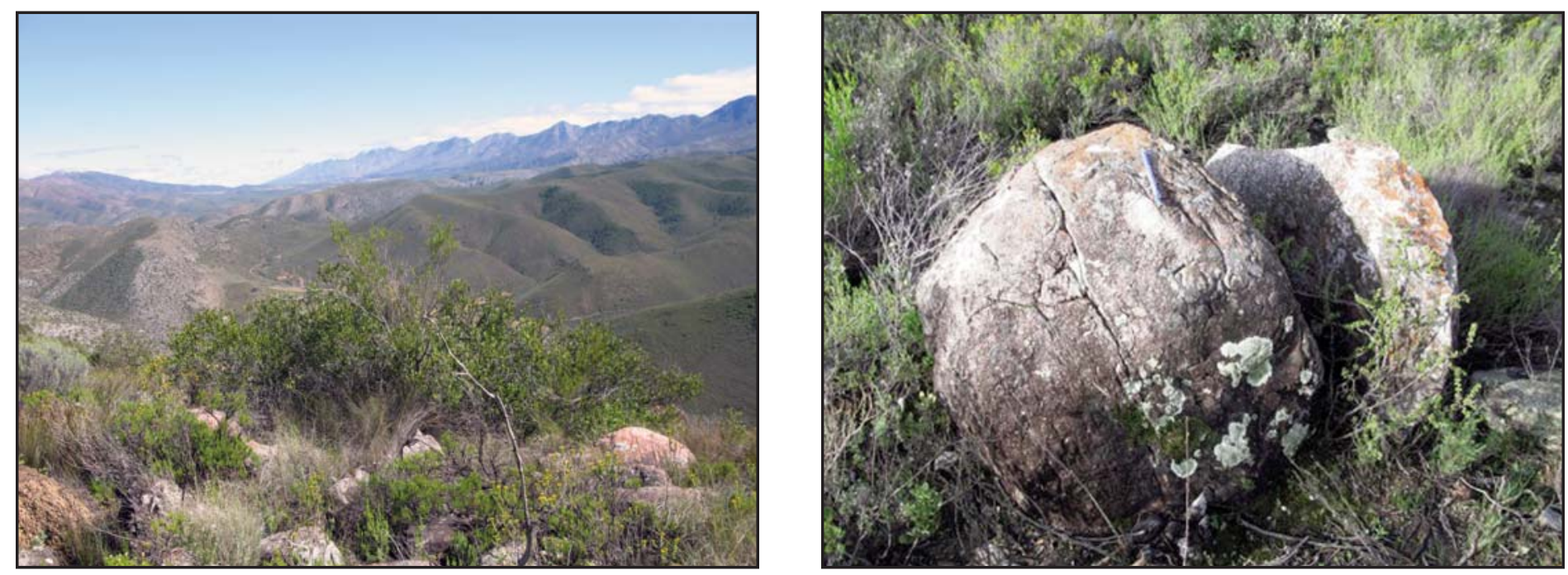

Figure 31. Topography across the Cango Valley with relatively well-preserved open paleo-river sections flanking the Swartberg Mountains and eroding at ca. 0.5 to $1.5 \mathrm{~m} / \mathrm{m} . \mathrm{y}$. over the last 5 m.y. (see below). The $1000 \mathrm{~m}$ asl topography in foreground (left) is covered by rounded quartzite boulders, in places with eroded impact textures (right), confirming their likely fossil link to Cretaceous paleo-river sections preserved at this high elevation.

\section{TECTONO-STRATIGRAPHIC LINKS - LOCAL TO GLOBAL}

\section{From Kango to Table Mountain - Orogeny and Epeirogeny}

While there are no granite plutons exposed across the Kango region, $\mathrm{U}-\mathrm{Pb}$ zircon dates from some granite boulders of the Kansa Group are ca. $518 \pm 9 \mathrm{Ma}$ (Barnett et al. 1997). Granite boulders from the base of the Sardinia Bay Formation in the Eastern Cape (Gamtoos Complex) also have a Cambrian age with dates at ca. $530 \pm 5 \mathrm{Ma}$ (Miller et al. 2016; Fig. 2b). Both are similar to the $\mathrm{U}-\mathrm{Pb}$ zircon dates obtained from the Neoproterozoic-Lower Paleozoic granite intrusions of the Western Cape at 560-500 Ma (Gresse et al. 2009), and in the southern Cape $(543 \mathrm{Ma}$, flanking George and Victoria Bay; Scheepers and Armstrong 2002). Therefore, the Cape Granite Suite is most likely to have been a source for the sediment (Fig. 27).

Specifically, the granite of Table Mountain in Cape Town, dated at ca. $540 \mathrm{Ma}(\mathrm{U}-\mathrm{Pb}$ zircon date; Scheepers and Armstrong 2002), unconformably underlies the baseline of TMG quartzite (Figs. 36 and 37). Based on U-Pb dated detrital zircons, this unconformity is younger here than ca. $520 \mathrm{Ma}$ (Armstrong et al. 1998); and perhaps younger than $504 \mathrm{Ma}$ based on the other $\mathrm{U}-\mathrm{Pb}$ detrital zircon dates from TMG in the Swartberg Mountains found directly above the Kango sequences (Fig. 33).

Final emplacement of the Table Mountain granite took place from ca. $15-18 \mathrm{~km}(5 \mathrm{kbar})$ at $750^{\circ} \mathrm{C}$, intruding the subvertical Malmesbury greywackes some 10-20 km below surface (Armstrong et al. 1998; Villaros et al. 2009; Harris and Vogeli 2010). Thus, this granite must have been uplifted and eroded by at least $15 \mathrm{~km}$ within 17-20 m.y. Along the seashore, the intruded Malmesbury Group is dated with detrital zircons at about $560 \mathrm{Ma}$, which is broadly similar to the greywackes of the Groenfontein Formation (the Geogamma Group, < 620 Ma; Fig. 37).
While there are no $\mathrm{Ar} / \mathrm{Ar}$ dates from rocks or minerals across the Kango Complex, such dates from the Cape Granite and its micas, calculated between 1996-2004 by Derek York and his colleagues in Canada (University of Toronto), provide a more detailed history of the cooling, multiple uplift, and erosion rates with relevance to the Kango Complex (Fig. 36).

The first dates at ca. $537 \pm 0.3 \mathrm{Ma}$ (MSWD of 0.79 ) are interpreted as the primary age of cooling of the samples through the muscovite and biotite closure temperatures. The very close agreement of ages from both minerals implies rapid cooling of the sample between their respective closure temperatures. These ages compare well with the $\mathrm{U}-\mathrm{Pb}$ zircon date of ca. $540 \pm 4 \mathrm{Ma}$ obtained from the same outcrop (Armstrong et al. 1998) and reveal onset of cooling (uplift) within less than 3 m.y. and erosion of $>15 \mathrm{~km}$ within 20 m.y., reaching a relatively low apparent temperature of $440^{\circ} \mathrm{C}$, well below the crystallization temperature of the Cape Granite and about 50 $100^{\circ} \mathrm{C}$ below the closure temperature of quartz-feldspar (Harris and Vogeli 2010).

The second dates at ca. $354.1 \pm 0.3 \mathrm{Ma}$ (MSWD of 0.84 ) apparently represent a reheating episode, sufficient to completely reset the K-feldspar, to affect over $20 \%$ of the biotite's $\mathrm{K}-\mathrm{Ar}$ budget, while affecting only $1.3 \%$ of the muscovite $\mathrm{K}-$ Ar budget, in agreement with the sequence of closure temperatures from highest (muscovite) through biotite to lowest (Kfeldspar). The weighted mean age of this overprint is dominated by a precise high-temperature isochron date of the $\mathrm{K}$ feldspar (Fig. 36). We interpret this age as a resetting of the Table Mountain granite/Malmesbury greywacke contact, and by inference the Kango Complex, during Carboniferous glaciation of the Dwyka Ice Age, which likely was covered by an up to 3-5 km thick Antarctic-like ice dome at $350 \mathrm{Ma}$ and that had completely melted by ca. $300 \mathrm{Ma}$ (e.g. Schulz et al. 2018). Thereafter, little is known about the subsequent erosion rates across Table Mountain, which today are less than 20 $\mathrm{m} / \mathrm{m} . \mathrm{y}$. (Erlanger et al. 2012). 

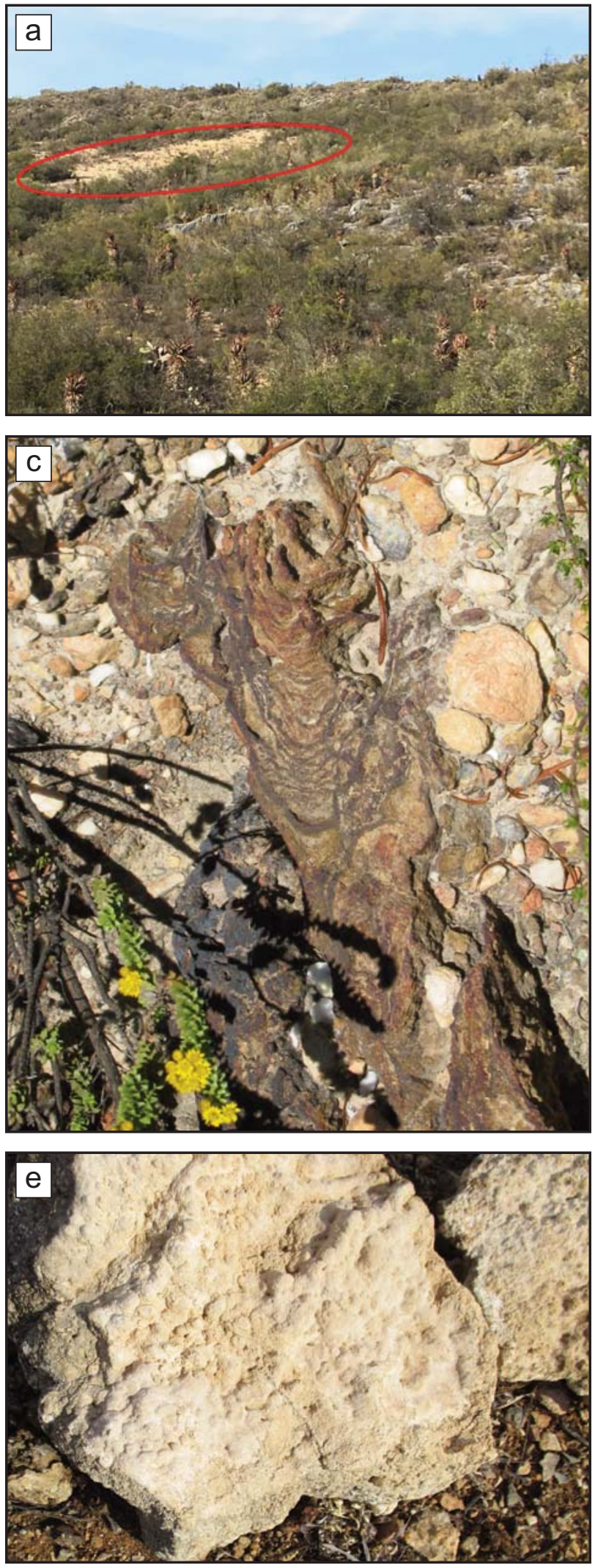
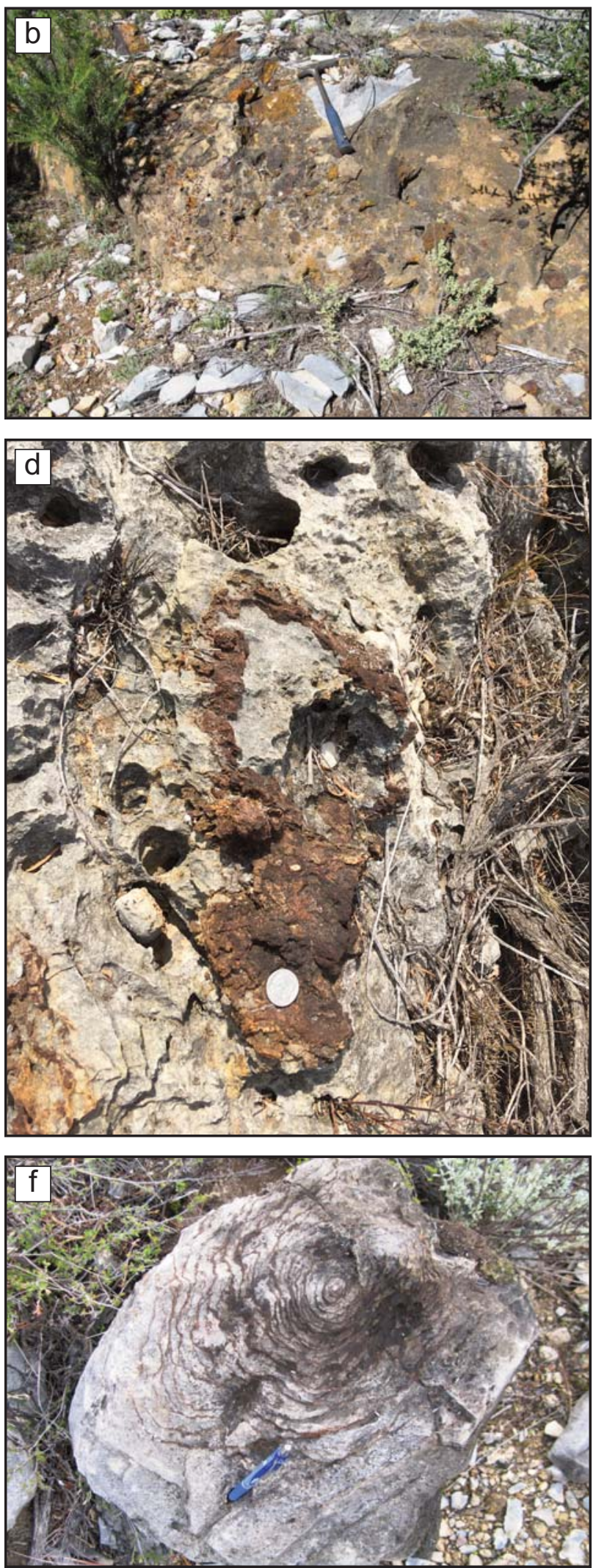

Figure 32. (a) Circular section of a $150 \mathrm{~m}$ wide paleo-cave (red ellipse) filled with yellow sand and conglomerate within the upper section of the Kombuis Formation (grey outcrops). (b) Cave-filled sandstone with clasts overlain by carbonate fragments (blue-grey) derived locally from the Kombuis carbonate rocks. (c) Iron precipitate (brown) covering the Cave sandstone and conglomerate. (d) Iron precipitate covering carbonate flanking the paleo-cave contact. (e) Carbonate precipitates (pale yellow) and (f) paleostalagmite(?) section (grey) flanking the contact with the Kombuis carbonate rocks. 


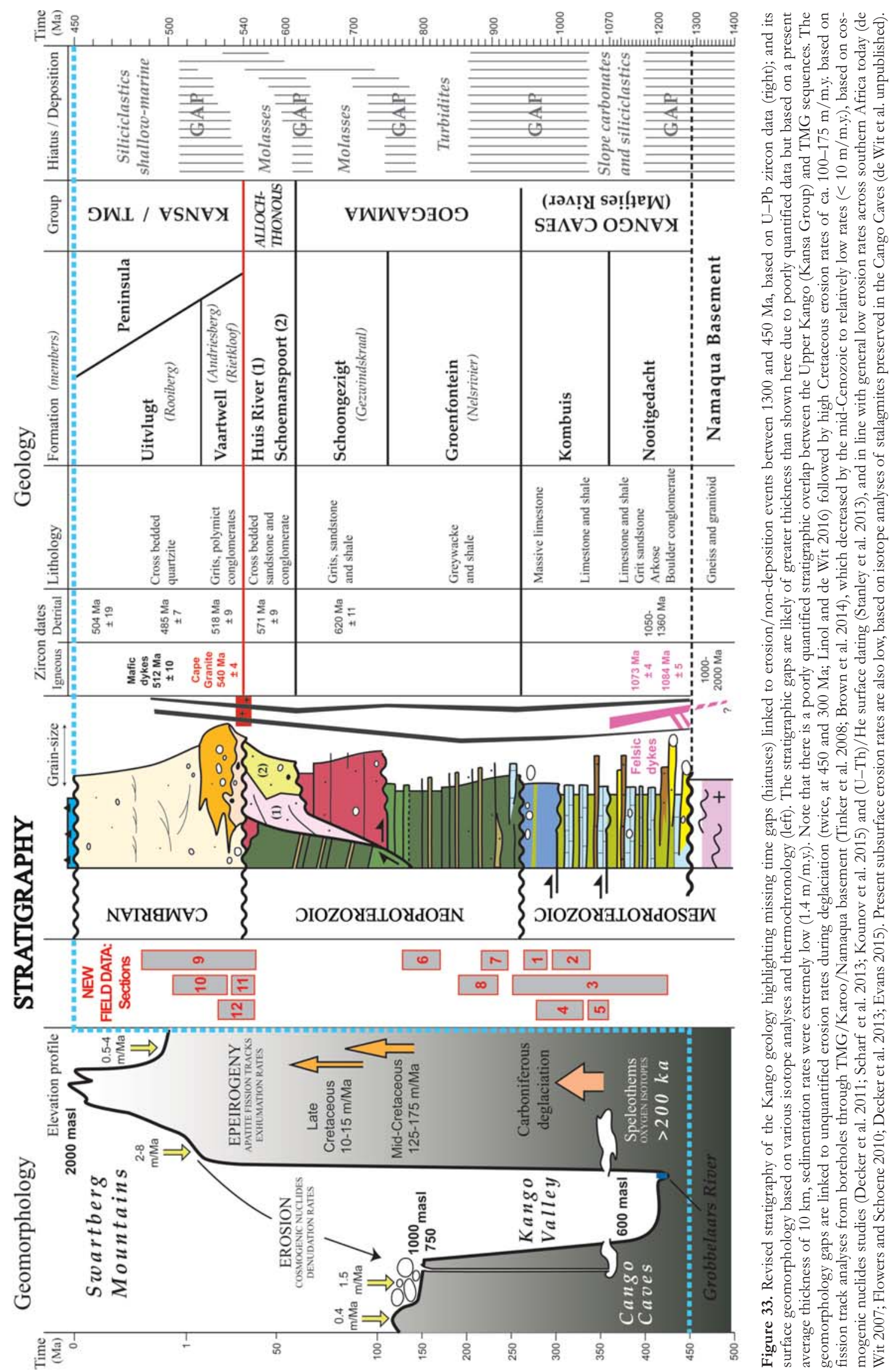




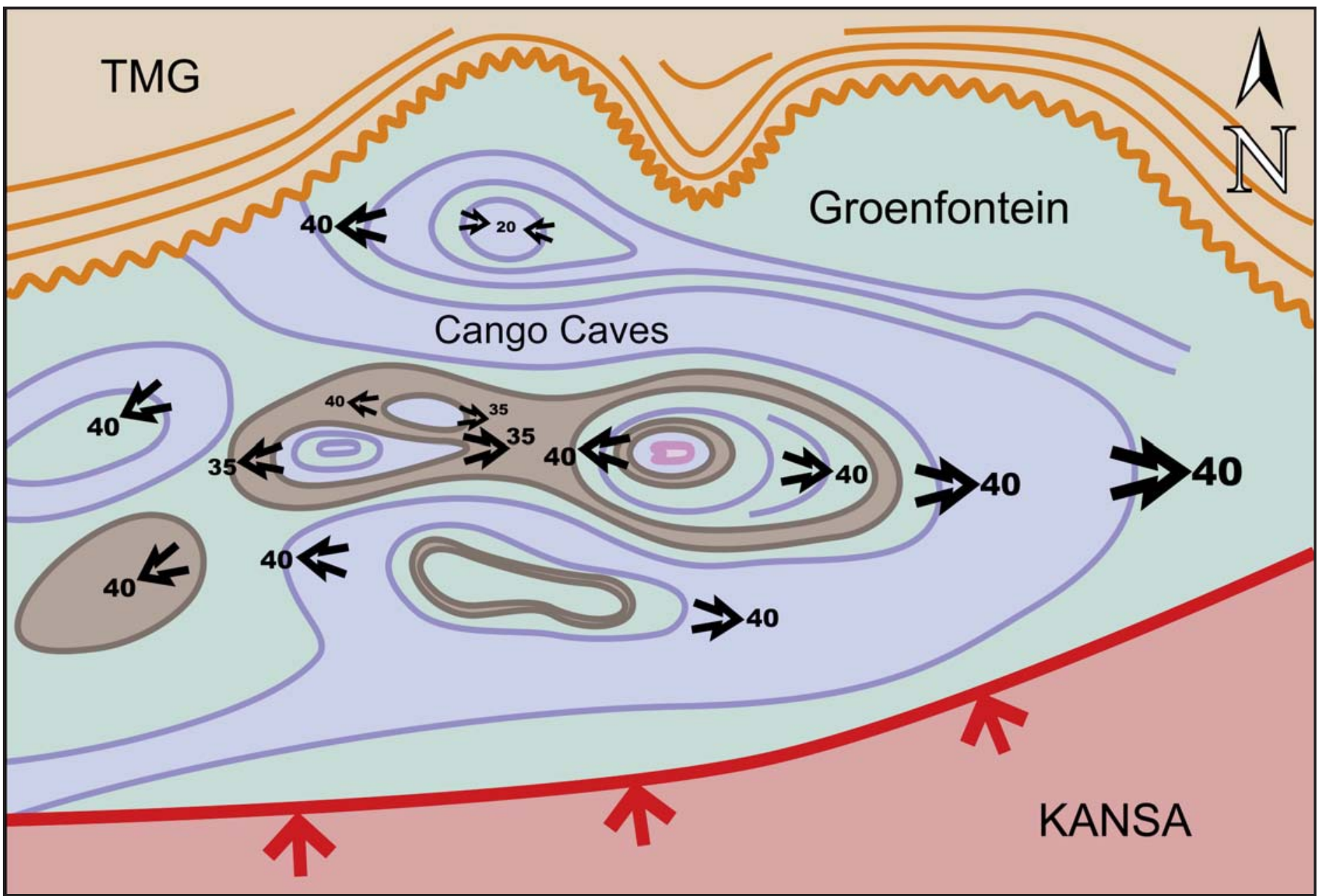

Figure 34. Simplified pre-Kansa/TMG restoration in the central part of the study area (by $50 \%$ at right angle across the cleavage/schistosity and along the fold closures) reveals a number of $8-12 \mathrm{~km}$ wide, $20-40^{\circ}$ dipping domes and basins across Namaquan/Grenvillian basement. These sequences were covered by molasse-like sandstones and conglomerates of the Kansa Group and the overlapping conglomerates and quartzites of the TMG, deposited during end-Pan African times (Fig. 33).
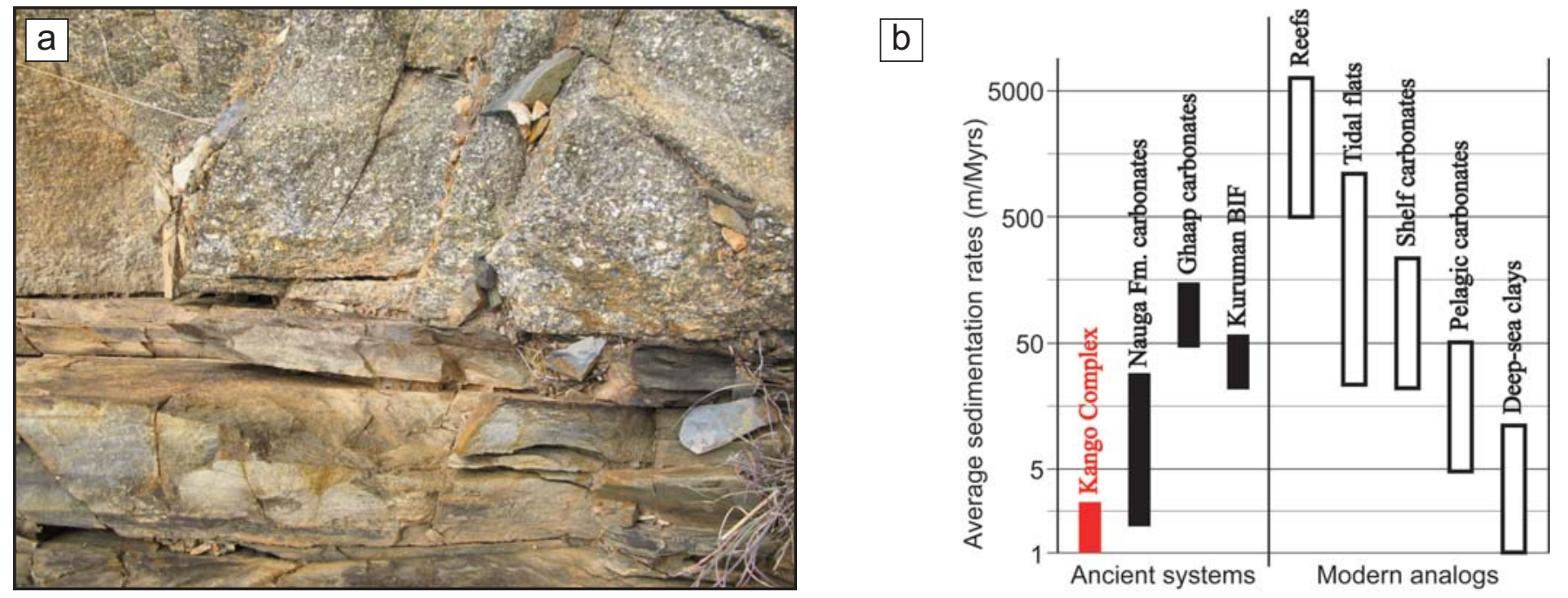

Figure 35. (a) Typical contact between parallel-bedded mudstone and feldspathic grit across the Kango Complex (Section 2). At present, there are no geochronological data that can quantify non-depositional/erosion breaks ('missing time') across these surfaces, which likely represent significant pauses in sedimentation and erosion, given the more than $700 \mathrm{~m}$.y. period recorded across the total $10 \mathrm{~km}$ thick stratigraphy. (b) Average deposition rates across variable sedimentary systems; the average accumulation rate of the Kango system is about $1.5 \mathrm{~m} / \mathrm{m}$.y. (highlighted in red), comparable only to the lowest sedimentation rates across modern deep oceans (modified from Altermann and Nelson 1998). 


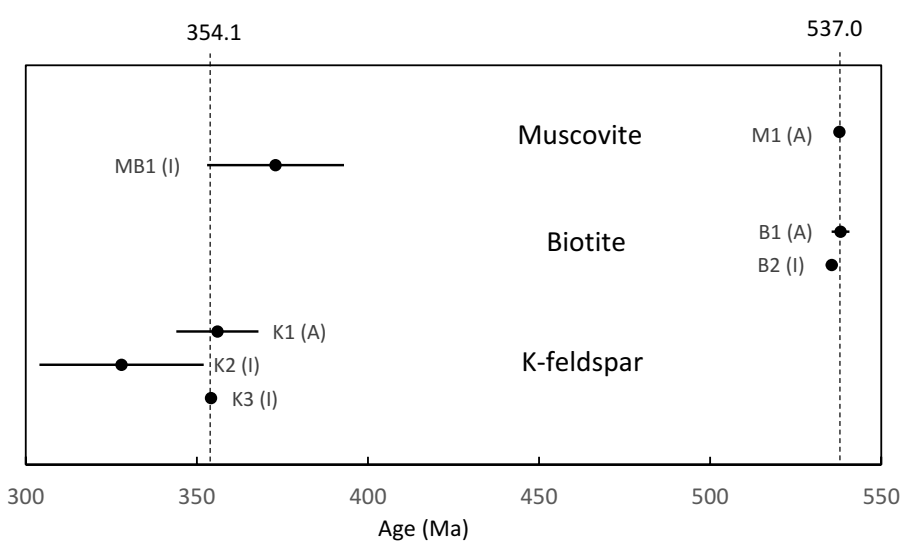

Figure 36. Detailed ${ }^{40} \mathrm{Ar} /{ }^{30} \mathrm{Ar}$ step heating results on single grains of biotite (11 steps), muscovite (16 steps) and K-feldspar (59 steps) from a whole-rock sample of the same Cape Granite reveal uplift/erosion during two distinct episodes.

\section{Across West Namaqualand}

Farther north, many U-Pb zircon dates of the Namaqua Natal Mobile Belt reveal igneous and metamorphic ages near the end of the Mesoproterozoic, between ca. 1230 and $1025 \mathrm{Ma}$ (Friese et al. 1996; Thomas et al. 1996; Barnett et al. 1997; McCourt et al. 2006; Cornell et al. 2006; Minnaar et al. 2017; Moen and Cornell 2017; Macey et al. 2018).

The closest regional stratigraphic equivalents of the Kango sequences are rocks exposed in West Namaqua and within the Saldania Belt near Cape Town (Fig. 38). The Namaquan basement is dated between about 2.0 and $1.0 \mathrm{Ga}$, including some late tectonic intrusions dated at ca. 1030-1100 Ma, and surrounding feldspathic quartzites (the Bitterfontein Subgroup; Joubert 1986), which are similar to those described and dated in this study of the Kango Complex. To compare with the Goegamma and Kansa groups the tectono-stratigraphy of the other time equivalent, Precambrian-Lower Paleozoic sequences across the Saldania Belt remains poorly resolved. This is due to limited field mapping, which prevents precise correlations for example with the Malmesbury Group (Fölling and Frimmel 2002; Frimmel 2018; Zimmermann 2018).

\section{From Gondwana to Rodinia}

Large uncertainties exist in the global paleogeographic reconstructions between about 1300 and $500 \mathrm{Ma}$, during deposition of the Kango sequences (e.g. Cawood et al. 2016; Merdith et al. 2017). However, possible connections during the Mesoproterozoic Namaquan-Grenvillian orogenies, and again during the Late Paleozoic Variscan-Gondwanan orogenies, suggest similar tectonic basin evolution in southern Africa and in northern America (Fig. 39).

The oldest sequences of limestone and feldspar-rich sandstone of the Kango Complex (including the Cango Caves limestone) were intruded by ca. 1070-1080 Ma old felsic dykes (Fig. 33). These earliest clastic sedimentary rocks are linked to rapid uplift and erosion of relatively low-pressure Namaqua granites and charnockites during their extensional unroofing flanking the Grenvillian Mountains system. While such basement rocks are not exposed in the Cango region, relatively abundant granite and pegmatite pebbles preserved in the lowest sequences suggest a close connection to a flat Namaquan basement that hosted shallow marine platforms which were the sources of carbonate slope conglomerates, breccias and turbidites linked to sea-level changes and extensional tectonics along a continental margin perhaps analogous to that proposed for the Paleozoic Cow Head-Fleur de Lys sequences in Newfoundland.

The Kango Caves Group limestone is unconformably overlain by the Goegamma Group comprising sandy turbidites and laminated siltstones deposited between 900 and $700 \mathrm{Ma}$ and linked to molasse-like sandstones and conglomerates in front of Pan-African mountain belts by ca. $620 \mathrm{Ma}$ (Fig. 39). These sequences were all disconformably overlain between 530 and $500 \mathrm{Ma}$ by shallow marine sandstones of the Kansa and Table Mountain groups, with conglomerates that contain granite boulders post-dating intrusion and erosion of granite down to sea level across the Western Cape at ca. $520 \mathrm{Ma}$, ahead of the onset of glaciation across southern Gondwana during the Early Paleozoic.

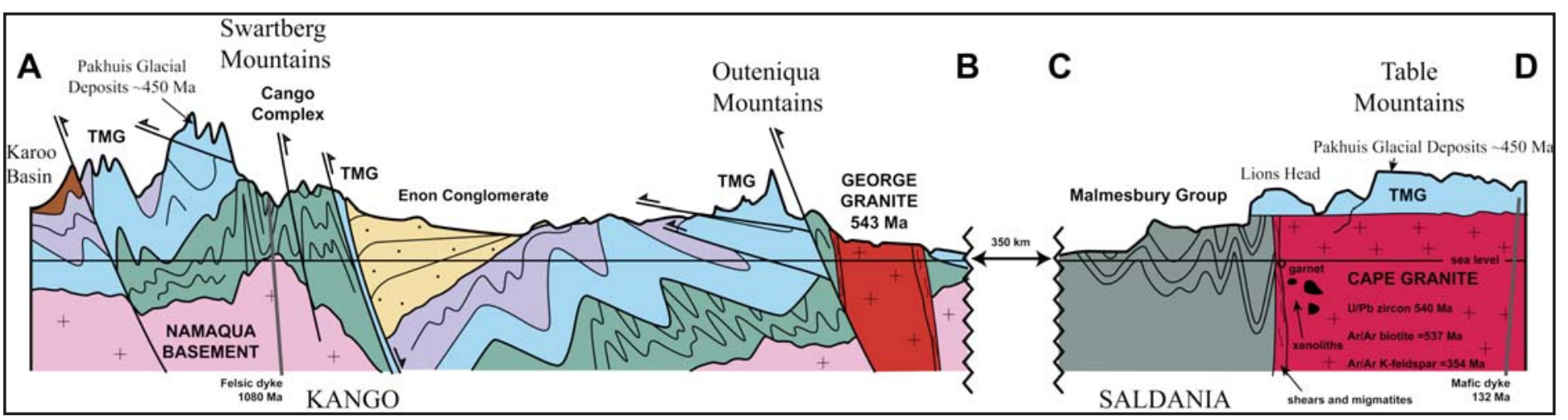

Figure 37. Schematic cross-sections of the Swartberg and Table mountains, highlighting chronostratigraphic differences between the Table Mountain Group (TMG) and its underlying sequences (Fig. 2a for location). In both areas the youngest dated detrital zircon grains from quartzites of the TMG that unconformably overlie granites and metasedimentary rocks range between 520 and $504 \mathrm{Ma}$, revealing a stratigraphic time gap of 20 to 100 m.y. between the Goegamma-Malmesbury and the Table Mountain groups. However, the precise ages of these sequences are poorly constrained: between 950 and $610 \mathrm{Ma}$ (for the Malmesbury - Scheepers 1995; Harris and Vogeli 2010); and between 1000 and $570 \mathrm{Ma}$ (for the Goegamma - Naidoo et al. 2013), respectively. No Archean zircon grains derived from the Kaapvaal Craton have been reported yet in the Kango and Saldania sequences as they have across the TMG (Scheepers and Armstrong 2002; Naidoo et al. 2013). There are still many outstanding data needed to test these possible links, including along the south coast near George (e.g. Gresse et al. 2009; Kirsters 2016; Kirsters and Belcher 2018). 


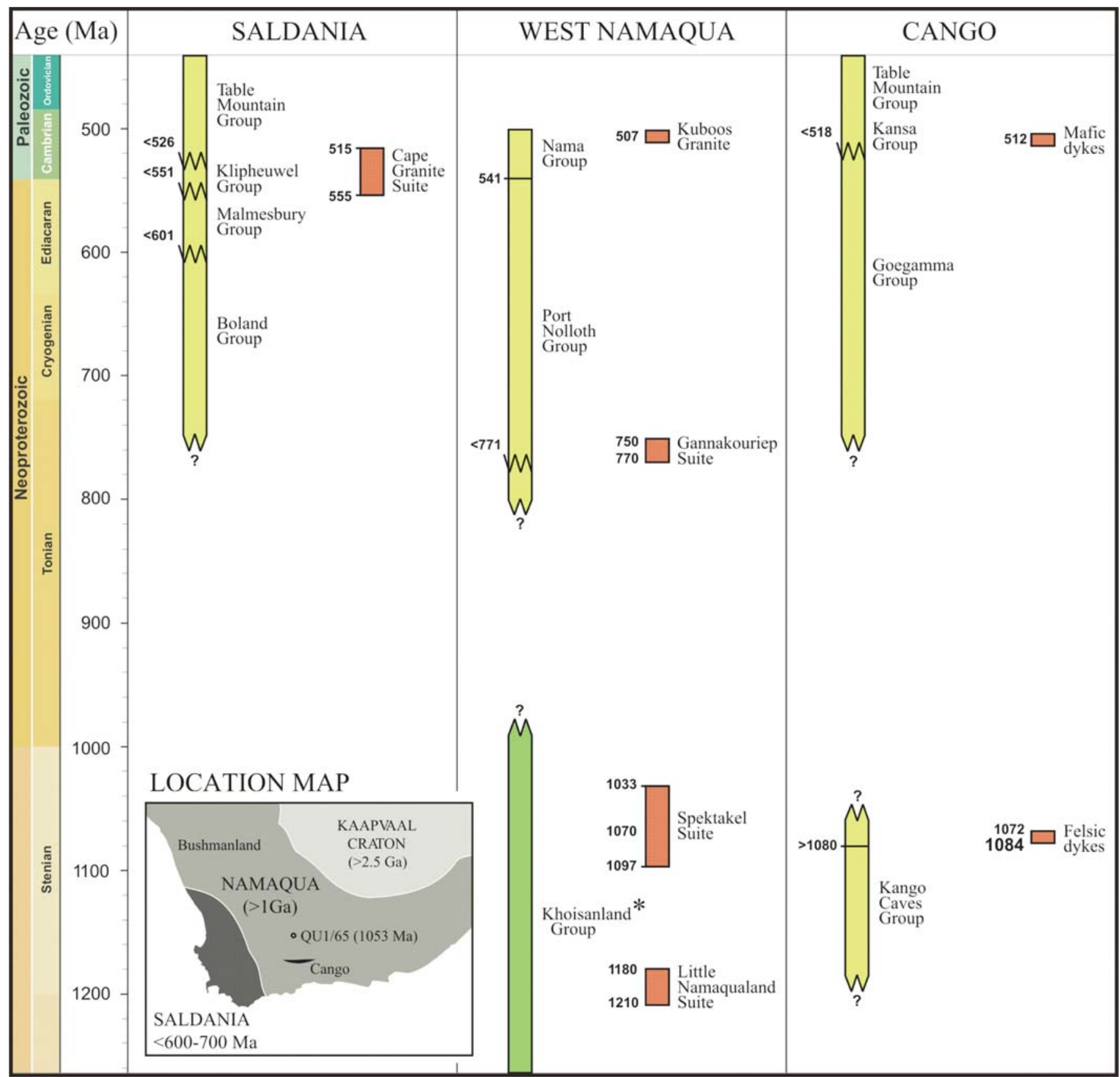

Figure 38. Stratigraphic table comparing sedimentary (yellow), high-grade low-pressure metamorphic (green), and intrusive (red) rock records from Namaqualand and Swartland with the Kango Complex, compiled from Joubert (1986), Barnett et al. (1997), Scheepers and Armstrong (2002), Eglington and Armstrong (2003), Frimmel et al. (2013), Frimmel (2018), and this study (right); see inset for location. Most maximum ages of sedimentation are uncertain due to limited field constraints, but most likely the Kango Caves Group correlates with similar quartzite-schist sequences (e.g. the Bitterfontein SubGroup) of the Khoisanland Group*.

* renamed after the colonial Bushmanland.

The Kango rocks thus trace the orogenic histories of Grenville and Appalachia across Canada to epeirogeny across South Africa, preserving a globally unique stratigraphic section that encapsulates this long history of changes from Rodinia to Africa.

\section{CONCLUSION}

The new geological map and detailed descriptions of sedimentary and deformational structures of a central-eastern section of the Cango region of southern South Africa improve our understanding of the regional stratigraphy. Together with new $\mathrm{U}-\mathrm{Pb}$ zircon dates of dykes and the existing geochronology, geophysics, geomorphology, cosmogenic nuclides and thermochronology, and global geodynamic models, this review provides a solid foundation for further field investigations.

The Kango Complex preserves a ca. 8-10 km lithostratigraphic record with a significant number of disconformities between 1200 and $500 \mathrm{Ma}$, with an average preservation rate 


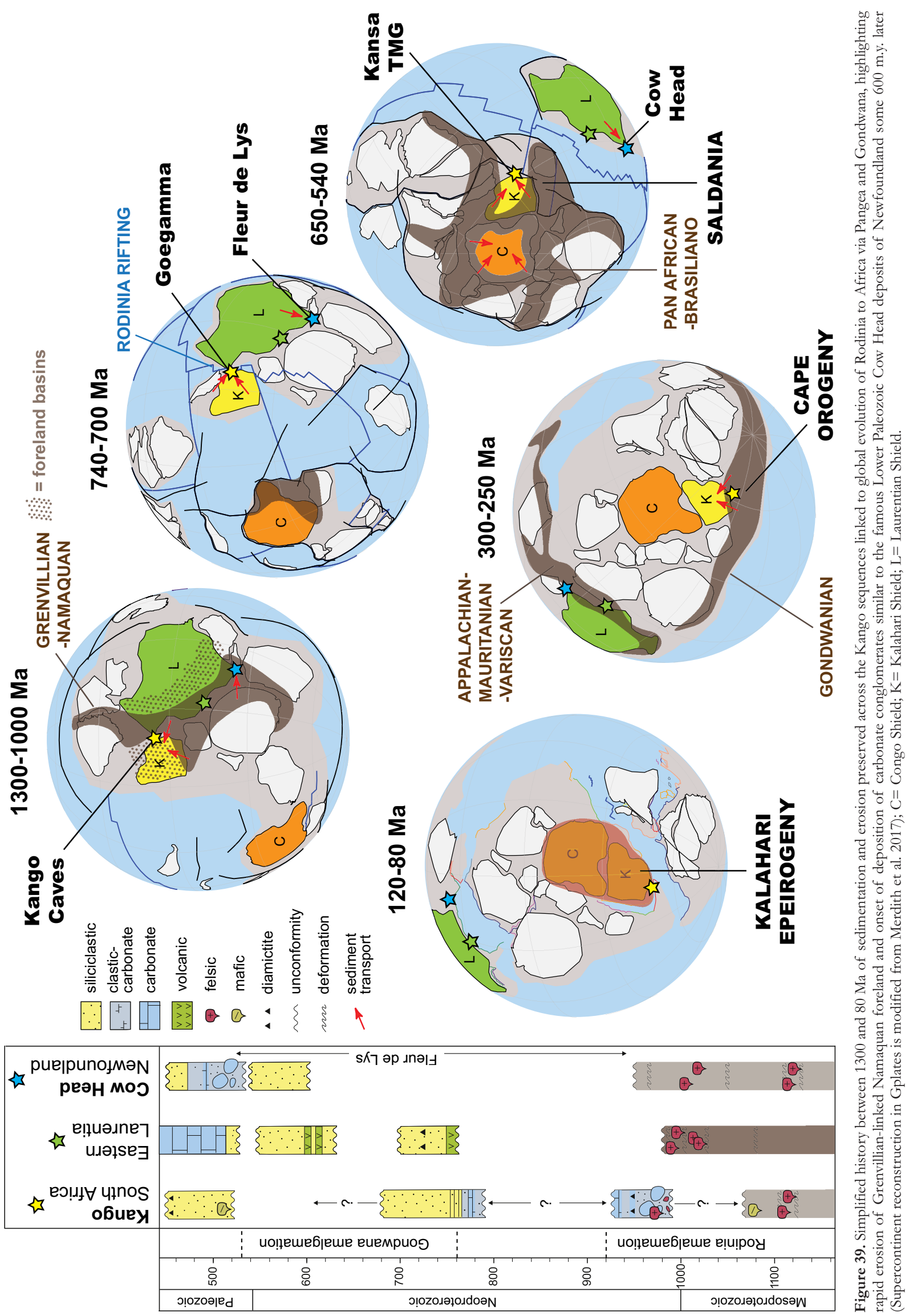


of about $1.5 \mathrm{~m} / \mathrm{m} . \mathrm{y}$., and thereafter overlapping in time with the Table Mountain Group (TMG) to at least $486 \mathrm{Ma}$. Between 450 and $350 \mathrm{Ma}$, these Kango and TMG sequences vertically subsided variably by up to $4 \mathrm{~km}$ below Antarctic-size ice sheets that yielded Pakhuis and Dwyka glacial deposits across southern Gondwana. After deglaciation by $300 \mathrm{Ma}$, and the Cape orogeny (252 Ma), the Kango Complex was uplifted vertically and eroded by ca. 3-5 km at rates between 100 and $200 \mathrm{~m} / \mathrm{m}$.y. during the Jurassic-Early Cretaceous, decreasing to less than $10 \mathrm{~m} / \mathrm{m} . \mathrm{y}$. today. These variable rates left a complex paleosurface and subsurface geomorphology across the Cango region, including different plateau elevations, valleys, canyons and caves.

Based on the low rates of sedimentation and erosion, the Kango Complex is a prime example of a long stratigraphic record with, apparently, more "Gaps than Records" (e.g. Ager 1973, 1992), but based on little age data. This recording deserves more testing through more innovative geo-timing (e.g. Bowring et al. 2006). The varied landscapes across the Cango region offer an excellent opportunity for new transdisciplinary sciences to try and close these gaps.

\section{ACKNOWLEDGEMENTS}

Andrew Hynes visited the Cango with Maarten de Wit in 2002 and provided inspirational suggestions, including potential links with Grenvillian and Appalachian sequences in Canada. It has taken nearly 15 years to document this, in part because we all know his expectations. Even earlier, Arthur Fuller (AF) first drove Maarten through the Cango following his arrival at University of Cape Town (UCT), making sure that he would follow up Arthur's field sedimentology there for more than 20 years, but which he never published; and thanks to Lester King for similar inspirations about the Cango geomorphology during a Gondwana workshop in 1979 at the Bernard Price Institute at Wits University. This would also not have happened without the visions of Louis Nicolaysen (LN). AF and LN were remarkable geologists, if somewhat elusive persons who completed their $\mathrm{PhDs}$ in Princeton University where AF got to know Albert Einstein, and where LN designed how best to display $\mathrm{Rb}-\mathrm{Sr}$ isotope data. Some of the early Kango whole-rock samples were dated by this method in the 1980s by Hugh Allsopp, and subsequently by U-Pb, following a decade of multi-disciplinary co-operation among earth scientists from six South African universities, and its Geological Survey, during the Inter Union Commission of Geodynamics of the IUGS and IUGG (Nicolayson 1983).

By 1995, Richard Armstrong dated the first zircon grains collected by honours student Wayne Barnett. Then during a following decade, Derek York completed the Table Mountain Ar-Ar analyses by 2006 following his sabbatical year in Cape Town in 1996. In 2004, the new U-Pb zircon dates of felsic dykes were completed by Kerstin Drost. Maarten owes them all a deep apology for letting this all remain in his proverbial drawers for so long.

We thank all undergraduate students of UCT (1996-2014) and Nelson Mandela University (2014-present) for their hard mapping during field classes, and all Masters $/ \mathrm{PhD}$ researchers that acted as field guides during these annual weeks to get away from their own routines. There are too many students $(>100)$ to mention individually, but they will remember their slogs in rain, snow and sunshine; and during their report writing. We also thank the managers of the Cango Caves and De Hoek Resort for putting up with these rowdy students for all those years.

Maarten, who left us during the finalization of this work, has inspired many young South Africans with the examples of the Kango. We would like to thank him for sharing his passion for field mapping and his enthusiasm in taking this transdisciplinary research forward.

This is AEON contribution 197 and Iphakade publication number 247.

\section{REFERENCES}

Ager, D.V., 1973, 1992, The Nature of the Stratigraphic Record (1st, 3rd editions): Macmillan, Chichester, 151 p., https://doi.org/10.1002/gj.3350290115.

Altermann, W., and Nelson, D.R., 1998, Sedimentation rates, basin analysis and regional correlations of three Neoarchaean and Palaeoproterozoic sub-basins of the Kaapvaal craton as inferred from precise U-Pb zircon ages from volcaniclastic sediments: Sedimentary Geology v. 120, p. 225-256, https://doi.org/10.1016/S0037-0738(98)00034-7.
Armstrong, R., de Wit, M.J., Reid, D., York, D., and Zartman, R., 1998, Cape Town's Table Mountain reveals rapid Pan African uplift of its basement rocks: Journal of African Earth Sciences, v. 27, p. 10-11.

Barnett, W., 1995, The geology of the Buffelsfontein 52 Farm - Oudtshoorn: Unpublished BSc thesis, University of Cape Town, 44 p., with detailed map.

Barnett, W., Armstrong, R.A., and de Wit, M.J., 1997, Stratigraphy of the upper Neoproterozoic Kango and lower Paleozoic Table Mountain Group of the Cape Fold Belt revisited: South African Journal of Geology, v. 100, p. 237-250.

Blewett, S.C.J., and Phillips, D., 2016, An overview of Cape Fold Belt geochronology: implications for sediment provenance and timing of orogenesis, in Linol B., and de Wit, M.J., eds., Origin and Evolution of the Cape Mountains and Karoo Basin: Regional Geology Reviews, p. 45-55, https://doi.org/10.1007/978-3319-40859-0_5.

Booth, P.W.K., 2011, Stratigraphic, structural and tectonic enigmas associated with the Cape Fold Belt: challenges for future research: South African Journal of Geology, v. 114, p. 235-248, https://doi.org/10.2113/gssajg.114.3-4.235

Bowring, S.A., Schoene, B., Crowley, J.L., and Ramezani, J., 2006, High-precision U$\mathrm{Pb}$ zircon geochronology and the stratigraphic record: Progress and promise: The Paleontological Society Papers, v. 12, p. 25-45, https://doi.org/10.1017/ S1089332600001339.

Brown, R., Summerfield, M., Gleadow, A., Gallagher, K., Carter, A., Beucher, R., and Wildman, M., 2014, Intracontinental deformation in southern Africa during the Late Cretaceous: Journal of African Earth Sciences, v. 100, p. 20-41, https://doi.org/10.1016/j.jafrearsci.2014.05.014.

Cawood, P.A, Strachan, R.A., Pisarevsky, S.A, Gladkochub, D.P., and Murphy, J.B., 2016: Linking collisional and accretionary orogens during Rodinia assembly and breakup: Implications for models of supercontinent cycles: Earth and Planetary Science Letters, v. 449, p. 118-126, https://doi.org/10.1016/j.epsl.2016.05.049.

Clifford, T.N., Gronow, J., Rex, D.C., and Burger, A.J., 1975, Geochronology and petrogenetic studies of high-grade metamorphic rocks and intrusives in Namaqualand, South Africa: Journal of Petrology, v. 16, p. 154-188, https://doi.org/10.1093/petrology/16.1.154.

Clifford, T.N., Stumpfl, E.F., Burger, A.J., McCarthy, T.S., and Rex, D.C., 1981, Mineral-chemical and isotopic studies of Namaqualand granulites, South Africa: A Grenville analogue: Contributions to Mineralogy and Petrology, v. 77, p. 225 250, https://doi.org/10.1007/BF00373538.

Coniglio, M., and Dix, G.R., 1992, Carbonate Slopes, in Walker, R.G., and James, N.P., eds., Facies Models - Response to sea level change: Geological Association of Canada, St. John's, NL, p. 349-373.

Cornell, D.H., and Pettersson, $\AA$., 2007, Ion probe zircon dating of metasediments from the Areachap and Kakamas Terranes, Namaqua-Natal Province and the stratigraphic integrity of the Areachap Group: South African Journal Geology, v. 110, p. 575-584, https://doi.org/10.2113/gssajg.110.4.575.

Cornell, D.H., Thomas, R.J., Moen, H.F.G., Reid, D.L., Moore, J.M., and Gibson, R.L., 2006, The Namaqua-Natal Province, in Johnson, M.R., Anhaeusser, C.R., and Thomas, R.J., eds., The Geology of South Africa, 2nd edition: Geological Society of South Africa, Johannesburg / Council for Geoscience, Pretoria, p. $325-380$.

Corstorphine, G.S., 1886, Notes on the Cango Cave: First Annual Report of the Geological Commission, Department of Agriculture, Cape Town, p 34-36.

Corstorphine, G.S., and Rogers, A.E., 1897, Report of a preliminary geological survey of the Outshoorn and Prince Albert Districts: Report of Geological Commission of Cape of Good Hope for 1896, Cape Town.

de Beer, C.H., and Macey, P.H., 2016a, Lithostratigraphy of the Mesoproterozoic Garies granite: South African Journal Geology, v. 119, p. 699-704 https://doi.org/10.2113/gssajg.119.4.699.

de Beer, C.H., and Macey, P.H., 2016b, Lithostratigraphy of the Mesoproterozoic Kliphoek granite: South African Journal Geology, v. 119, p. 705-712, https://doi.org/10.2113/gssajg.119.4.705.

de Wit, M.J., 2007, The Kalahari epeirogeny and climate change: differentiating cause and effect from core to space: Inkaba yeAfrica special volume, South African Journal of Geology, v. 110, p. 367-392, https://doi.org/10.2113/ gssajg.110.2-3.367

de Wit, M.J., Stankiewicz, J., and Reeves, C., 2008, Restoring Pan-African-Brasiliano connections: more Gondwana control, less Trans-Atlantic corruption, in Pankhurst, R.J., Trouw, R.A.J., de Brito Neves, B.B., and de Wit, M.J., eds., West Gondwana: Pre-Cenozoic Correlations Across the South Atlantic Region: Geological Society, London, Special Publications, v. 294, p. 399-412, https://doi.org/10.1144/SP294.20.

Decker, J.E., Niedermann, S., and de Wit, M.J., 2011, Soil erosion rates in South Africa compared with cosmogenic ${ }^{3} \mathrm{He}$-based rates of soil production: South African Journal of Geology, v. 114, p. 475-488, https://doi.org/10.2113/ gssajg.114.3-4.475 
Decker J.E., Niedermann, S., and de Wit, M.J., 2013, Climatically influenced denudation rates of the southern Africa plateau: Clues to solving a geomorphic paradox: Journal of Geomorphology, v. 190, p. 48-60, https://doi.org/10.1016/ j.geomorph.2013.02.007.

Dewey, J.F., Robb, L., and van Schalkwyk, L., 2006, Did Bushmanland extensionally unroof Namaqualand?: Precambrian Research, v. 150, p. 173-182, https://doi.org/10.1016/j.precamres.2006.07.007.

Dunn, E.J., 1875, Geological Sketch Map of Cape Colony compiled by E. J. Dunn from observations made by Messrs. A. C. Bain, Wylie, T. Bain, Jun., Dr. Atherstone, R. Pinchin, and the Compiler: London, 23 miles to 1 inch. (1887; Also in the first Geological sketch map of South Africa).

Egle, S., 1996, Orogenic-induced fluid flow through the Cape Fold Belt- Karoo Basin: Unpublished $\mathrm{PhD}$ thesis, University Vienna, Austria.

Egle, S., Hoernes, S., and de Wit, M.J., 1995, Paleo-fluid speciation and migration in the Cape Fold Belt and Karoo Basin: Centennial International Geocongress of South Africa Geological Society, Johannesburg, Extended Abstract, p. 713-716.

Egle, S., de Wit, M.J., and Hoernes, S., 1998, Gondwana fluids and subsurface paleohydrology of the Cape Fold belt and the Karoo Basin, South Africa: Journal of African Earth Sciences, v. 27, p. 63-64.

Eglington, B.M., 2006, Evolution of the Namaqua-Natal Belt, southern Africa - a geochronological and isotope geochemical review: Journal of African Earth Sciences, v. 46 p. 93-111, https://doi.org/10.1016/j.jafrearsci.2006.01.014.

Eglington, B.M., and Armstrong, R.A., 2003, Geochronological and isotopic constraints on the Mesoproterozoic Namaqua-Natal Belt: evidence from deep borehole intersections in South Africa: Precambrian Research, v. 125, p. 179 189, https://doi.org/10.1016/S0301-9268(02)00199-7.

Erlanger, E.D., Granger, D.E., and Gibbon R.J., 2012, Rock uplift rates in South Africa from isochron burial dating of fluvial and marine terraces: Geology, v. 40, p. 1019-1022, https://doi.org/10.1130/G33172.1.

Evans, M.Y., 2015, The geology, sedimentology, geochronology and palaeo-environmental reconstruction of the Heelbo Hillslope Deposit, Free State Province, South Africa: Unpublished $\mathrm{PhD}$ thesis, University Witwatersrand, Johannesburg, SA, 387 p.

Flowers R.M., and Schoene, B., 2010, (U-Th)/He thermochronometry constraints on unroofing of the eastern Kaapvaal craton and significance for uplift of the southern African Plateau: Geology, v. 38, p. 827-830, https://doi.org/10.1130/ G30980.1.

Fölling, P., 2000, Chemostratigraphic correlation and $\mathrm{Pb}-\mathrm{Pb}$ dating of carbonate sequences in the external Gariep belt and Kango inlier of the Saldania belt in Namibia and South Africa: Unpublished PhD thesis, University of Cape Town, 251p.

Fölling, P.G., and Frimmel, H.E., 2002, Chemostratigraphic correlations of carbonate successions in the Gariep and Saldania Belts, Namibia and South Africa: Basin Research, v. 14, p. 69-88, https://doi.org/10.1046/j.1365-2117. 2002.00167.x

Friese, A.E.W., Charlesworth, E.G., and McCarthy, T.S., 1995, Tectonic processes within the Kaapvaal Craton during the Kibaran (Grenville) Orogeny: structural, geophysical and isotopic constraints from the Witwatersrand Basin and environments: Information Circular, 292, University of the Witwatersrand, 67 p.

Frimmel, H.E., 2009, Trace element distribution in Neoproterozoic carbonates as palaeoenvironmental indicator: Chemical Geology, v. 258, p. 338-353, https://doi.org/10.1016/j.chemgeo.2008.10.033.

Frimmel, H.E., 2018, The Gariep Belt, in Siegesmund, S., Basei, M., Oyhantçabal, P., and Oriolo, S., eds., Geology of Southwest Gondwana: Regional Geology Reviews, Springer Cham, p. 353-386, https://doi.org/10.1007/978-3-31968920-3_13.

Frimmel, H.E., Fölling, P.G., and Diamond, R., 2001, Metamorphism of the PermoTriassic Cape Fold Belt and its basement: Mineralogy and Petrology, v. 73, p. 325-346, https://doi.org/10.1007/s007100170005.

Frimmel, H.E, Basei M.A.S., Correa V.X., and Mbangula, N., 2013, A new lithostratigraphic subdivision and geodynamic model for the Pan-African western Saldania Belt, South Africa: Precambrian Research, v. 231, p. 218-235, https://doi.org/10.1016/j.precamres.2013.03.014.

Gaucher, C., and Germs, G.J.B., 2006, Recent advances in South African Neoproterozoic-Early Palaeozoic biostratigraphy: correlation of the Cango Caves and Gamtoos Groups, and acritarchs of the Sardinia Bay Formation, Saldania Belt: South African Journal of Geology, v. 109, p. 193-214, https://doi.org/ 10.2113/gssajg.109.1-2.193.

Goedhart, M.L., and Booth, P.W.K., 2016, A palaeoseismic trench investigation of early Holocene neotectonic faulting along the Kango Fault, southern Cape Fold Belt, South Africa - Part I: stratigraphic and structural features: South African Journal of Geology, v. 119, p. 545-568, https://doi.org/10.2113/ gssajg.119.3.545.
Gresse, P.G., Booth, P.W.K., Frimmel, H.E., Hälbich, I., Le Roux, J.P., and Schone, R.W., 1993, The Neoproterozoic Saldania Belt and the Cape Fold Belt in the southern Cape: tectonostratigraphy, structure, mineralization, and possible correlations: Field school guidebook, Geological Society of South Africa, 53 p.

Gresse, P.G., von Veh, M.W., and Frimmel, H.E., 2009, Namibian (Neoproterozoic) to early Cambrian successions, in Johnson, M.R., Anhaeusser, C.R., and Thomas, R.J., eds., The Geology of South Africa, 2nd edition: Geological Society of South Africa, Johannesburg/Council for Geoscience, Pretoria, p. 395342.

Haas, R., 1998, Geology of the western Kango Inlier along the Gamka River (with detailed map): Unpublished thesis, University of Stuttgart.

Hälbich, I.W., 1983a, A tectonogenesis of the Cape Fold Belt, in Söhnge, A.P.G., and Hälbich, I.W., eds, Geodynamics of the Cape Fold Belt: Special Publication of the Geological Society of South Africa, v. 12, p. 165-176.

Hälbich, I.W., 1983b, A geodynamic model for the Cape Fold Belt in the Republic of South Africa, in Söhnge, A.P.G., and Hälbich, I.W., eds., Geodynamics of the Cape Fold Belt: Special Publication of the Geological Society of South Africa, v. 12 , p. $177-184$.

Harris, C., and Vogeli, J., 2010, Oxygen isotope composition of garnet in the Peninsula Granite, Cape Granite Suite, South Africa: Constraints on melting and emplacement mechanisms: South African Journal of Geology, v. 113, p. 401412, https://doi.org/10.2113/gssajg.113.4.401

Hartnady, C.J.H., 1969, Structural analyses of some pre-Cape formations in the Western Province: University of Cape Town, Precambrian Research Unit, Bulletin no. $6,70 \mathrm{p}$

Hiscott, R.N., and James, N.P., 1985, Carbonate debris flows, Cow Head Group, western Newfoundland: Journal of Sedimentary Petrology, v. 55, p. 735-745, https://doi.org/10.1306/212F87D3-2B24-11D7-8648000102C1865D.

James, N.P., and Stevens, R.K., 1986, Stratigraphy and correlation of the CambroOrdovician Cow Head Group, western Newfoundland: Geological Survey of Canada, Bulletin 366, 143 p., https://doi.org/10.4095/125053.

Joubert, P., 1986, Namaqualand - a model of Proterozoic accretion?: South African Journal of Geology, v. 89, p. 79-96.

King, G., and Bailey, G., 2006, Tectonics and human evolution: Antiquity, v. 80, p. 265-286, https://doi.org/10.1017/S0003598X00093613.

King, L.C., 1951, South African Scenery, Second ed.: Oliver and Boyd, Edinburgh.

King, L.C., 1967, South African Scenery: A Textbook of Geomorphology, Third ed.: Oliver and Boyd, Edinburgh and London.

Kirsters, A., 2016, What lies beneath Table Mountain or all models are wrong, but some are useful: Inaugural lecture, Stellenbosch University, South Africa, https://www.sun.ac.za/english/Inaugurallectures/Inaugural\%20lectures/InauguralLectureProfAlexKisters.pdf

Kirsters, A., and Belcher, R., 2018, The stratigraphy and structure of the western Saldania Belt, South Africa and geodynamic implications, in Siegesmund, S., Basei, M., Oyhantçabal, P., and Oriolo, S., eds., Geology of Southwest Gondwana: Regional Geology Reviews, Springer Cham, p. 387-410, https//doi.org/ 10.1007/978-3-319-68920-3_14.

Kounov, A., Niedermann, S., de Wit, M.J., Codilean, A.T.,Viola, G., Andreoli, M., and Christl, M., 2015, Cosmogenic ${ }^{21} \mathrm{Ne}$ and ${ }^{10} \mathrm{Be}$ reveal a more than $2 \mathrm{Ma}$ alluvial fan flanking the Cape Mountains, South Africa: South African Journal Geology, v. 118, p. 129-144, https://doi.org/10.2113/gssajg.118.2.129.

Le Roux, J.P., 1977, The stratigraphy, sedimentology and structure of the Cango Group, north of Oudtshoorn: Unpublished M.Sc. thesis, University of Stellenbosch, South Africa, 149 p.

Le Roux, J.P., 1983, Structural evolution of the Kango Group, South Africa, in Söhnge, A.P.G., and Hälbich, I.W., eds., Geodynamics of the Cape Fold Belt: Geological Society of South Africa Special Publication, v. 12, p. 47-56.

Le Roux, J.P., 1997, Cycle hierarchy of a Neoproterozoic carbonate-siliciclastic shelf: Matjies River Formation of the Kango Group, South Africa: South African Journal of Geology, v. 100, p. 1-10.

Le Roux, J.P., and Gresse, P.G., 1983, The sedimentary-tectonic realms of the Kango Group, in Söhnge, A.P.G., and Hälbich, I.W., eds., Geodynamics of the Cape Fold Belt: Special Publication of the Geological Society of South Africa v. 12, p. 33-45.

Le Roux, J.P., and Smit, P.H., 1995, Macro- and mesoscale features of the Potgieterspoort thrust, Kango Group: South African Journal of Geology, v. 98, p. 5-12.

Lindeque, A.S., Ryberg, T., Stankiewicz, J., Weber, M.H., and de Wit, M.J., 2007, Deep crustal seismic reflection experiment across the southern Karoo Basin, South Africa: South African Journal of Geology, v. 110, p. 419-438, https://doi.org/10.2113/gssajg.110.2-3.419.

Lindeque, A., de Wit, M.J., Ryberg, T., Weber, M., and Chevallier, L., 2011, Deep crustal profile across the southern Karoo Basin and Beattie Magnetic Anomaly, South Africa: An integrated interpretation with tectonic implications: South 
African Journal of Geology, v. 114, p. 265-292, https://doi.org/10.2113/ gssajg.114.3-4.265.

Linol B., and de Wit, M.J., editors, 2016, Origin and Evolution of the Cape Mountains and Karoo Basin: Regional Geology Reviews, Springer Cham, 193 p., https://doi.org/10.1007/978-3-319-40859-0.

Luttman-Johnson, H.M., 1897, Sketch plan of the Cango Cave: First Annual Report of the Geological Commission, Department of Agriculture, Cape Town.

Macey, P.H., Bailie, R.H., Miller, J.A., Thomas, R.J., de Beer, C., Frei, D., and Le Roux, P.J., 2018, Implications of the distribution, age and origins of the granites of the Mesoproterozoic Spektakel Suite for the timing of the Namaqua Orogeny in the Bushmanland Subprovince of the Namaqua-Natal Metamorphic Province, South Africa: Precambrian Research, v. 312, p. 68-98, https://doi.org/10.1016/j.precamres.2018.02.026.

McCourt, S., Armstrong, R.A., Grantham, G.H., and Thomas, R.J., 2006, Geology and evolution of the Natal belt, South Africa: Journal of African Earth Sciences, v. 46, p. 71-92, https://doi.org/10.1016/j.jafrearsci.2006.01.013.

McIntyre, R.C., 1932, The geology of the Cango beds: Transactions of Geological Society of South Africa, v. 35, p. 69-84.

Merdith, A.S., Williams, S.E., Müller, R.D., and Collins, A.S., 2017, Kinematic constraints on the Rodinia to Gondwana transition: Precambrian Research, v. 299, p. 132-150, http://dx.doi.org/10.1016/j.precamres.2017.07.013.

Miller, W., Armstrong, R., and de Wit, M.J., 2016, Geology and U/Pb geochronology of the Gamtoos Complex and lower Paleozoic Table Mountain Group, Cape Fold Belt, Eastern Cape, South Africa: South African Journal of Geology, v 119, p. 147-170, https://doi.org/10.2113/gssajg.119.1.147.

Minnaar, H., Cornell, D.H., and Bailie, R.H., 2017, Lithostratigraphy of the Mesoproterozoic Bethesda Formation: South African Journal Geology, v. 120, p. 187-192, https://doi.org/10.25131/gssajg.120.1.187.

Moen, H.F.G., and Cornell, D.H., 2017, Lithostratigraphy of the Mesoproterozoic Wilgenhoutsdrif Group: South African Journal of Geology, v. 120, p. 201-208, https://doi.org/10.25131/gssajg.120.1.201.

Naidoo, T., 2008, Provenance of the Neoproterozoic to Early Palaeozoic Kango Inlier, Oudtshoorn, South Africa: Unpublished MSc thesis, University Johannesburg, $259 \mathrm{p}$.

Naidoo, T., Zimmermann, U., and Chemale Jr., F., 2013, The evolution of Gondwana: $\mathrm{U}-\mathrm{Pb}, \mathrm{Sm}-\mathrm{Nd}, \mathrm{Pb}-\mathrm{Pb}$ and geochemical data from Neoproterozoic to Early Palaeozoic successions of the Kango Inlier (Saldania Belt, South Africa): Sedimentary Geology, v. 294, p. 164-178, https://doi.org/10.1016/j.sedgeo. 2013.05.014

Nel, R., Germs, G.J.B., Praekelt, H.E., and Odendaal, A.I., 2018, Re-examination and reinterpretation of the stratigraphy of the Matjies River Formation, Cango Caves Group, Neoproterozoic to early Palaeozoic Saldania Belt, South Africa: South African Journal of Geology, v. 121, p. 451-462, https://doi.org/ 10.25131/sajg. 121.0030 .

Nicolaysen, L.O., 1983, Preface in Special Publication 12, Geodynamics of the Cape Fold Belt, Geological Society of South Africa, by National correspondent of SA National Geodynamics Programme, 1974-1980.

Praekelt, H.E., Germs, G.J.B., Kennedy, J.H., 2008, A distinct unconformity in the Cango Caves Group of the Neoproterozoic to early Paleozoic Saldania Belt in South Africa: its regional significance: South African Journal of Geology, v. 111, p. 357-368, https://doi.org/10.2113/gssajg.111.4.357.

Reid, D.L., and Barton, E.S., 1983, Geochemical characterization of granitoids in Namaqualand geotraverse, in Botha, B.J.V., ed., Namaqualand Metamorphic Complex: Special Publication Geological Society of South Africa, v. 10, p. $67-$ 82.

Reid, D.L., Welke, H.J., Erlank, A.J., and Betton, P.J., 1987, Composition, age and tectonic setting of amphibolites in the central Bushmanland Group, western Namaqua Province, southern Africa: Precambrian Research, v. 36, p. 99-126, https://doi.org/10.1016/0301-9268(87)90084-2.

Rogers, A.W., and Schwartz, E.H.L., 1900, Report on Oudtshoorn: Report of Geological Commission of Cape of Good Hope for 1986, Cape Town.

Scharf, T.E., Codilean, A.T., de Wit, M.J., Jansen, J.D., and Kubik, P.W., 2013, Strong rocks sustain ancient postorogenic topography in southern Africa: Geology, v. 41, p. 331-334, https://doi.org/10.1130/G33806.1

Scheepers, R., 1995, Geology, geochemistry and petrogenesis of Late Precambrian S-, I- and A-type granitoids in the Saldania belt, western Cape Province, South Africa: Journal of African Earth Science, v. 21, p. 35-58, https://doi.org/ 10.1016/0899-5362(95)00087-A.

Scheepers, R., and Armstrong, R.A., 2002, New U-Pb SHRIMP zircon ages of the Cape Granite Suite: implications for the magmatic evolution of the Saldania Belt: South African Journal of Geology v. 105, p. 241-256, https://doi.org/ $10.2113 / 1050241$.

Schulz, H.-M., Linol, B., de Wit, M.J., Schuck, B., Schaepan, I., and Wirth, R., 2018 ,
Early diagenetic signals archived in black shales of the Dwyka and Lower Ecca Groups of the southern Karoo Basin (South Africa): Keys to the deglaciation history of Gondwana during the Early Permian, and its effect on potential shale gas storage: South African Journal of Geology, v. 121, p. 69-94, https://doi.org/10.25131/sajg.121.0004.

Shone, R.W., and Booth, P.W.K., 2005, The Cape basin, South Africa: A review: Journal of African Earth Sciences, v. 43, p. 196-210, https://doi.org/10.1016/j.jafrearsci.2005.07.013.

Söhne, A.P.G., and Hälbich, I.W., 1983, Geodynamics of the Cape Fold Belt: Special Publication 12, Geological Society of South Africa, 184 p. (with detailed maps).

Stankiewicz, J., Ryberg, T., Schulze, A., Lindeque, A., Weber, M.H., and de Wit, M.J., 2007, Initial results from the wide-angle seismic refraction lines in the southern Cape: Inkaba yeAfrica special volume, South African Journal of Geology, v. 110, p. 407-418, https://doi.org/10.2113/gssajg.110.2-3.407.

Stanley, J.R, Flowers, R.M., and Bell, D.R., 2013, Kimberlite (U-Th)/He dating links surface erosion with lithospheric heating, thinning, and metasomatism in the southern African Plateau: Geology, v. 41, p. 1243-1246, https://doi.org/ 10.1130/G34797.1.

Stocken, C.G., 1954, The Pre-Cape rocks of the central Cango: Unpublished PhD thesis, University of Cape Town, 73 p.

Thomas, R.J., de Beer, C.H., and Bowring, S.A., 1996, A comparative study of the Mesoproterozoic late orogenic porphyritic granitoids of southwest Namaqualand and Natal, South Africa: Journal of African Earth Sciences, v. 23, p. 485 508, https://doi.org/10.1016/S0899-5362(97)00014-6.

Tinker, J., de Wit, M.J., and Brown, R., 2008, Mesozoic exhumation of the southern Cape, South Africa, quantified using apatite fission track thermochronology: Tectonophysics, v. 455, p. 77-93, https://doi.org/10.1016/j.tecto.2007.10.009.

van Staden, A., 2011, Provenance analysis the Neoproterozoic to lower Paleozoic glacial (?) deposits from southwestern Gondwana: Unpublished $\mathrm{PhD}$ thesis, University of Johannesburg, $308 \mathrm{p}$.

van Staden, A., Naidoo, T., Zimmemann, U., and Germs, G.J.B., 2006, Provenance analysis of selected clastic rocks in Neoproterozoic to lower Paleozoic successions of southern Africa from the Gariep Belt and Kango Inlier: South African Journal of Geology, v. 109, p. 215-232, https://doi.org/10.2113/gssajg.109.12.215

Villaros, A., Stevens, G., and Buick, I.S., 2009, Tracking S-type granite from source to emplacement: clues from garnet in the Cape Granite Suite: Lithos, v. 112, p. 217-235, https://doi.org/10.1016/j.lithos.2009.02.011.

Walker, R.G., and James, N.P., editors, 1992, Facies models: response to sea level change: Geological Association of Canada, St. John's, NL, 409 p.

Waters, D.J., 1986, Metamorphic zonation and thermal history of pelitic gneisses from western Namaqualand, South Africa: South African Journal of Geology, v. 89 , p. $97-102$.

Waters, D.J., 1990, Thermal history and tectonic setting of the Namaqualand granulites, southern Africa: clues to Proterozoic crustal development, in Vielzeuf, D., and Vidal, P., eds., Granulites and Crustal Evolution: NATO ASI Series, Springer, Dordrecht, v. 311, p. 243-256, https://doi.org/10.1007/978-94-0092055-2 13.

Weckmann, U., Ritter, O., Chen, X., Tietze, K., and de Wit, M.J., 2012, Magnetotelluric image linked to surface geology across the Cape Fold Belt, South Africa: Terra Nova, v. 24, p. 207-212, https://doi.org/10.1111/j.13653121.2011.01054.x.

Zimmermann, U., 2018, The provenance of selected Neoproterozoic to lower Paleozoic basin successions of southwest Gondwana: A review and proposal for further research, in Siegesmund, S., Basei, M., Oyhantçabal, P., and Oriolo, S., eds., Geology of Southwest Gondwana: Regional Geology Reviews, Springer Cham, p. 561-591, https://doi.org/10.1007/978-3-319-68920-3_21.

\section{Received May 2020 \\ Accepted May 2020}

For access to the de Wit et al. (2020) Supplementary Material: Appendix: U-Pb dated zircon grains from selected felsic dykes of the lower Kango Complex (Sections 5 and 6, Map 1), and $\mathrm{U}-\mathrm{Pb}$ data tables and plots for samples K08-01, -02 , and -03 , please visit the GAC's open source GC Data Repository for the Andrew Hynes Series: Tectonic Processes at: https://gac.ca/gc-datarepository/. 

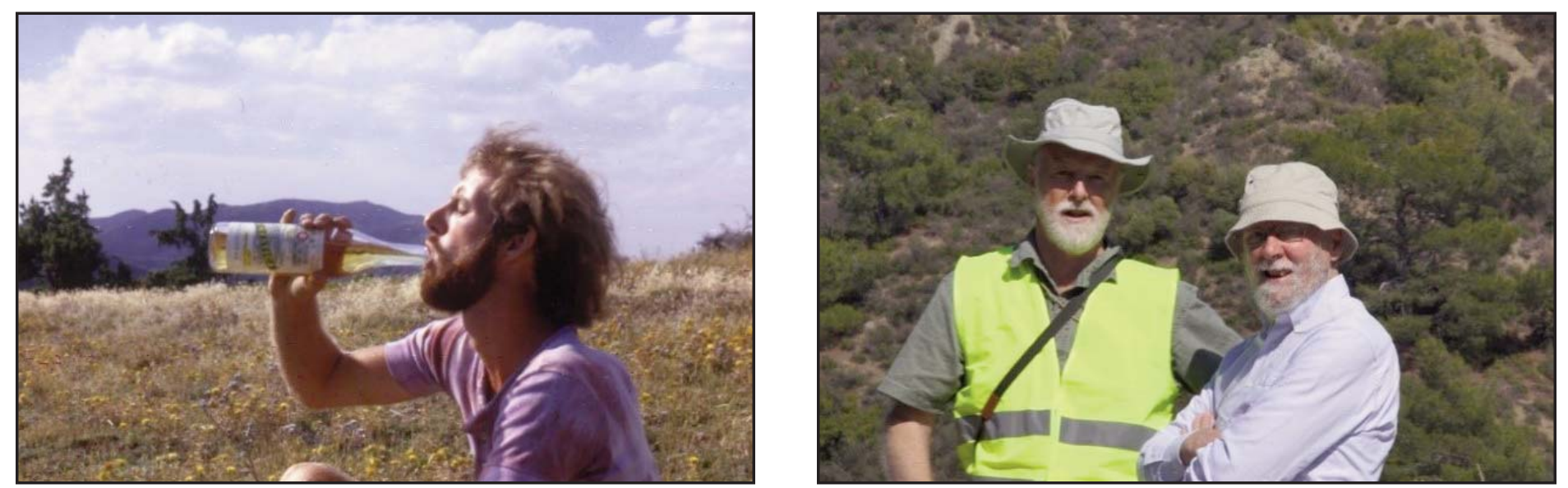

Andrew investigating the geology of Greece during his $\mathrm{PhD}$ studies and much later in a celebratory trip with his supervisor Alan Smith. 